\title{
Assessment of Industrial Load for Demand Response across U.S. Regions of the Western Interconnect
}

\section{September 2013}

Prepared by

Michael Starke

Nasr Alkadi

Oak Ridge National Laboratory

Ookie Ma

DOE - EERE

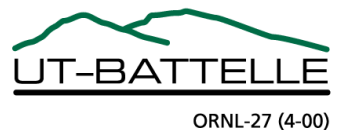




\section{DOCUMENT AVAILABILITY}

Reports produced after January 1, 1996, are generally available free via the U.S. Department of Energy (DOE) Information Bridge.

Web site http://www.osti.gov/bridge

Reports produced before January 1, 1996, may be purchased by members of the public from the following source.

National Technical Information Service

5285 Port Royal Road

Springfield, VA 22161

Telephone 703-605-6000 (1-800-553-6847)

TDD 703-487-4639

Fax 703-605-6900

E-mail info@ntis.gov

Web site http://www.ntis.gov/support/ordernowabout.htm

Reports are available to DOE employees, DOE contractors, Energy Technology Data Exchange (ETDE) representatives, and International Nuclear Information System (INIS) representatives from the following source.

Office of Scientific and Technical Information

P.O. Box 62

Oak Ridge, TN 37831

Telephone 865-576-8401

Fax 865-576-5728

E-mail reports@osti.gov

Web site http://www.osti.gov/contact.html

This report was prepared as an account of work sponsored by an
agency of the United States Government. Neither the United States
Government nor any agency thereof, nor any of their employees,
makes any warranty, express or implied, or assumes any legal
liability or responsibility for the accuracy, completeness, or
usefulness of any information, apparatus, product, or process
disclosed, or represents that its use would not infringe privately
owned rights. Reference herein to any specific commercial product,
process, or service by trade name, trademark, manufacturer, or
otherwise, does not necessarily constitute or imply its endorsement,
recommendation, or favoring by the United States Government or
any agency thereof. The views and opinions of authors expressed
herein do not necessarily state or reflect those of the United States
Government or any agency thereof.




\title{
Assessment of Industrial Load for Demand Response across U.S. Regions of the Western Interconnect
}

\author{
Prepared for \\ Energy Efficiency and Renewable Energy \\ U.S. DEPARTMENT OF ENERGY \\ Washington, D.C. 20585 \\ Prepared by \\ OAK RIDGE NATIONAL LABORATORY \\ Oak Ridge, Tennessee 37831 \\ Managed by \\ UT-BATTELLE, LLC \\ For the \\ U.S. DEPARTMENT OF ENERGY \\ Under contracts \\ DE-AC02-05CH11231, DE-AC05-00OR22725, and \\ DE-AC36-08GO28308
}




\section{ACKNOWLEDGEMENTS}

The work described in this report was funded by the Department of Energy Office of Energy Efficiency and Renewable Energy under Contract Nos. DE-AC02-05CH11231, DE-AC0500OR22725, and DE-AC36-08GO28308 and by the Alliance for Sustainable Energy, LLC through subcontract AGG-1-11946-01. The opinions represented in this report are the authors' own and do not reflect the views of the Department of Energy or the U.S. Government. The authors would like to thank Brendan Kirby for his technical advice during this project.

In addition, we wish to recognize the following individuals for their review and input:

- Walter Brockway, Manager Global Energy Efficiency, ALCOA

- Michael Caufield, Global Energy Efficiency Specialist, ALCOA

- Daryl Letto, Manager, Applications Engineering, Enbala Power Networks

- Professor Fangxing Li, Department of Computer and Electrical Engineering, University of Tennessee at Knoxville (UTK). 


\section{ABSTRACT}

Demand response has the ability to both increase power grid reliability and potentially reduce operating system costs. Understanding the role of demand response in grid modeling has been difficult due to complex nature of the load characteristics compared to the modeled generation and the variation in load types. This is particularly true of industrial loads, where hundreds of different industries exist with varying availability for demand response.

We present a framework considering industrial loads for the development of availability profiles for demand response that can provide more regional understanding and can be inserted into analysis software for further study. The developed framework utilizes a number of different informational resources, algorithms, and real-world measurements to perform a "bottom-up" approach in the development of a new database with representation of the potential demand response resource in the industrial sector across the U.S. This tool houses statistical values of energy and demand response potential by industrial plant and geospatially locates the information for aggregation for different territories without proprietary information. This report will discuss this framework and the analyzed quantities of demand response for Western Interconnect in support of evaluation of the cost production modeling with power grid modeling efforts of demand response. Additional work is still needed to incorporate the results of this work into production cost modeling software and other grid simulation tools.

Keywords: Industrial Demand Response, Ancillary Services, Load Modeling, Resource Evaluation, IGATE-E@. 


\section{FORWARD}

This report is one of a series stemming from the U.S. Department of Energy (DOE) Demand Response and Energy Storage Integration Study. This study is a multi-National Laboratory effort to assess the potential value of demand response and energy storage to electricity systems with different penetration levels of variable renewable resources and to improve our understanding of associated markets and institutions. This study was originated, sponsored, and managed jointly by the Office of Energy Efficiency and Renewable Energy and the Office of Electricity Delivery and Energy Reliability.

Grid modernization and technological advances enable resources, such as demand response and energy storage, to support a wider array of electric power system operations. Historically, thermal generators and hydropower in combination with transmission and distribution assets have been adequate to serve customer loads reliably and with sufficient power quality, even as variable renewable generation like wind and solar power become a larger part of the national energy supply. While demand response and energy storage can serve as alternatives or complements to traditional power system assets in some applications, their values are not entirely clear. This study seeks to address the extent to which demand response and energy storage can provide cost-effective benefits to the grid and to highlight institutions and market rules that facilitate their use.

The project was initiated and informed by the results of two DOE workshops; one on energy storage and the other one on demand response. The workshops were attended by members of the electric power industry, researchers, and policymakers; and the study design and goals reflect their contributions to the collective thinking of the project team. Additional information and the full series of reports of these workshops can be found at www.eere.energy.gov/analysis/. 


\section{TABLE OF CONTENTS}

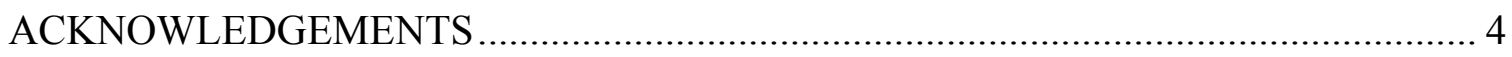

ABSTRACT

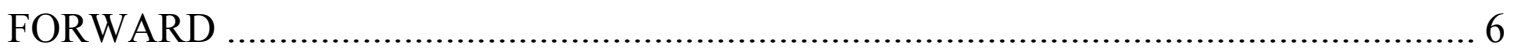

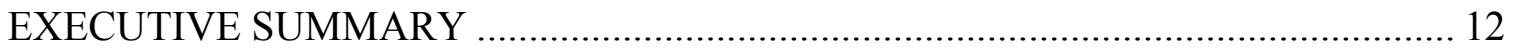

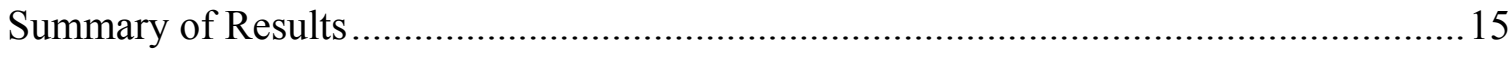

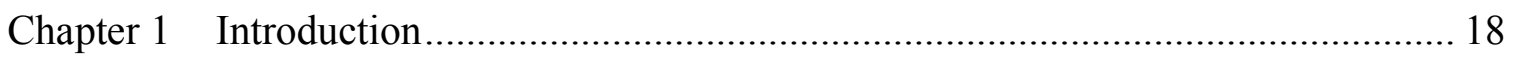

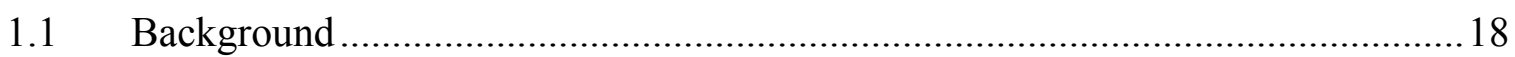

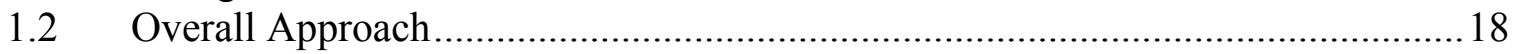

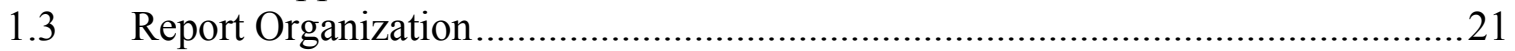

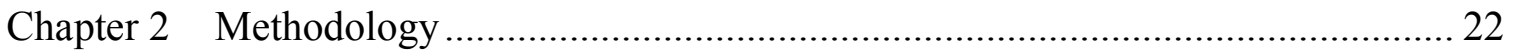

2.1 Electrical Energy Consumption Estimation by Manufacturing Plant.....................22

2.2 Daily Load Curve Development for Industrial Processes......................................25

2.3 Selection of Top Industrial Subsectors for DR Analysis …………......................28

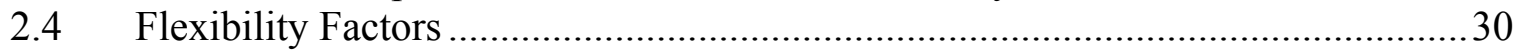

2.4.1 Industrial Load Types ............................................................................. 31

2.4.2 Derivation of the Industrial Demand Response Flexibility-Factor (IDRFF).....31

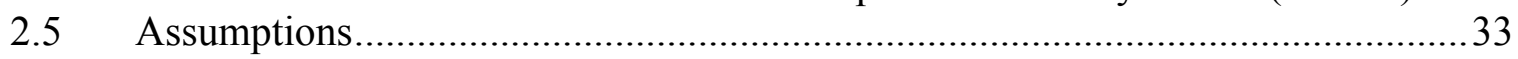

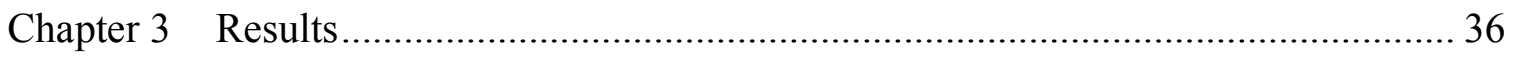

3.1 Industrial DR Profiles Aggregation in Western Interconnect (WI) ........................36

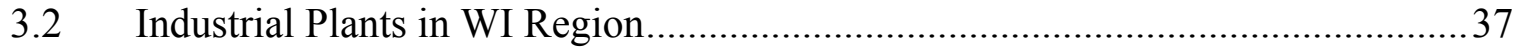

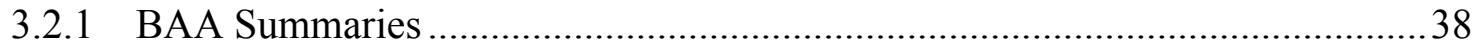

Chapter 4 CONCLUSIONS, AND FUTURE RESEARCH …………………….......... 49

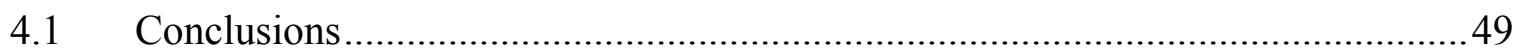

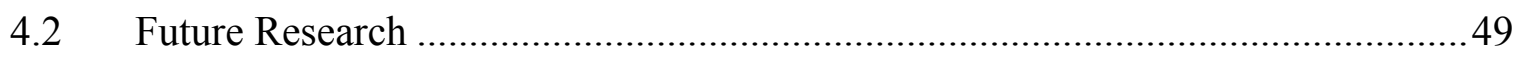

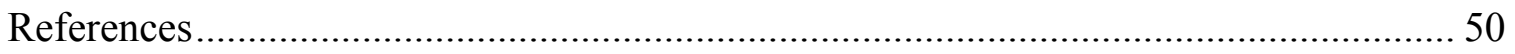

APPENDIX A Industrial Energy Estimation Approach.................................................. 54

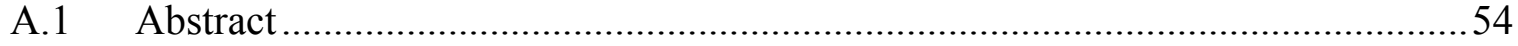

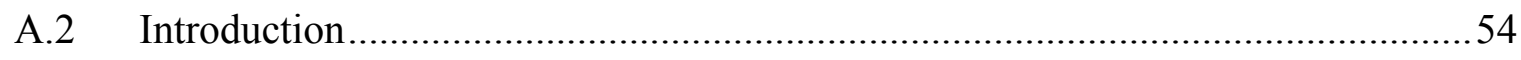

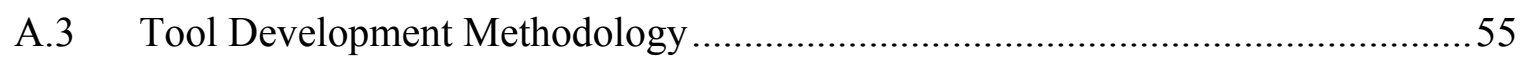

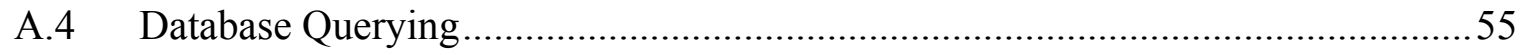

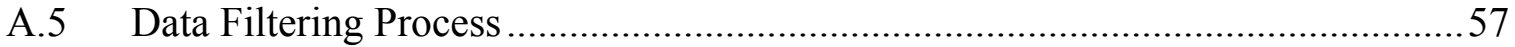




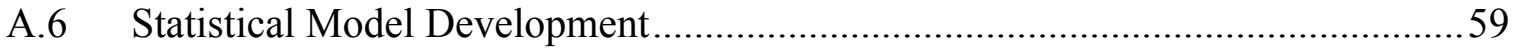

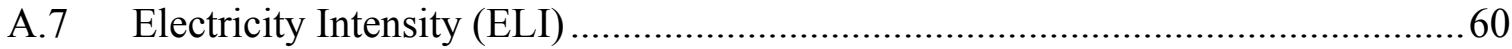

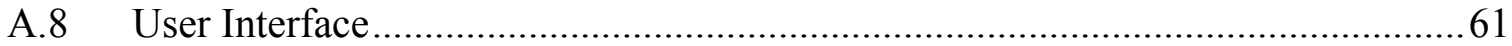

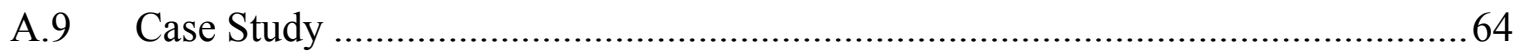

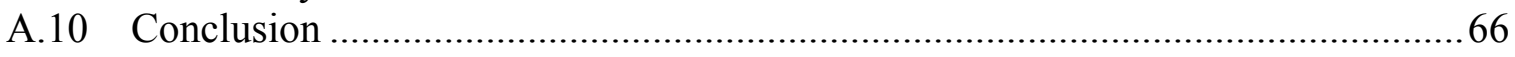

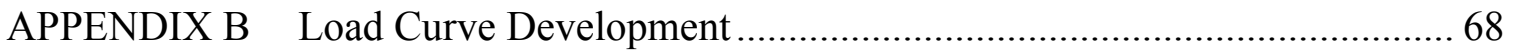

B.1 Genetic Algorithms (GA) Method to Create the LOAD Curve.............................68

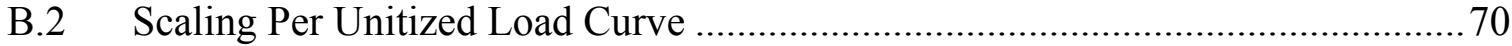

B.3 Breakdown of Load Curve Based on Process Steps ............................................ 70

B.4 Graphical Representation of Manufacturing Plants .......................................... 72

APPENDIX C Demand Response Potential in Industrial Sector ............................... 74 


\section{LIST OF FIGURES}

Figure

Figure 1.1 Overall Approach ................................................................... 19

Figure 1.2 Balancing Authority Areas (BAAs). Boundaries are approximate.

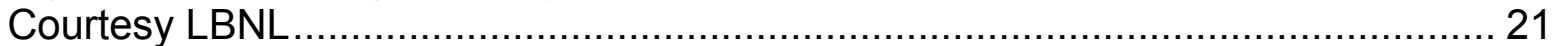

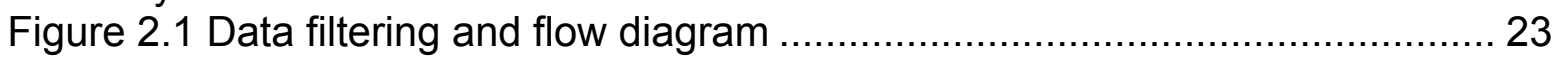

Figure 2.2 Regression Analysis - Flat Glass Industry (SIC 3211).................... 23

Figure 2.3 Comparison of Modeled Electrical Energy Versus EIA-MECS Published

Data [Table C7., 2011] (Using Bottom up Approach) .................................... 24

Figure 2.4 Actual (with breakdowns) vs. Estimated Total Industrial Electrical Energy Consumption in WI region - Note: Logarithmic Scale .................................... 25

Figure 2.5. Load Factor calculation results based on DOE-IAC Field Data * ........ 26

Figure 2.6. Per-Unitized Load Curve for SIC 32 Using Genetic Algorithm (GA) .... 27

Figure 2.7 Daily Load Curve for Dominating Processes for SIC $32 \ldots \ldots \ldots \ldots \ldots \ldots \ldots . . \ldots 28$

Figure 3.1 Process flow to establish final available DR quantities ..................... 36

Figure 3.2 Count of Industries Selected in WI Zone by Two-Digit SIC* ............... 37

Figure 3.3 Estimated Electrical Energy Consumption of All Industries in WI Region

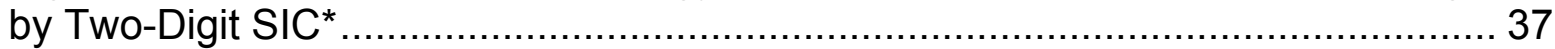

Figure 3.4 Actual (with breakdowns) vs. Estimated Total Industrial Electrical Energy

Consumption in WI Zone ........................................................................ 38

Figure 3.5 Regulation Availability by MW per BAA (Scenario 1) ..................... 40

Figure 3.6 Contingency Availability by MW per BAA (Scenario 1) ..................... 40

Figure 3.7 Flex Availability by MW per BAA (Scenario 1) ............................... 41

Figure 3.8 Energy Availability by MW per BAA (Scenario 1) .......................... 41

Figure 3.9 Capacity Availability by MW per BAA (Scenario 1) ......................... 42

Figure 3.10 Regulation Availability by MW per BAA (Scenario 2) ..................... 42

Figure 3.11 Contingency Availability by MW per BAA (Scenario 2) ...................43 43

Figure 3.12 Flex Availability by MW per BAA (Scenario 2) ............................ 43

Figure 3.13 Energy Availability by MW per BAA (Scenario 2) .......................... 44

Figure 3.14 Capacity Availability by MW per BAA (Scenario 2) ........................ 44

Figure 3.15 Hourly Aggregated Industrial Load Curves (458 Four-Digit SICs

representing 458 industrial subsectors) broken by each BAA in Western

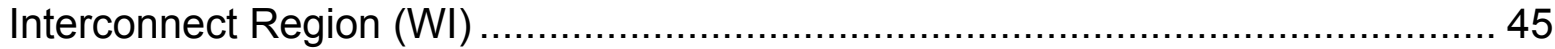

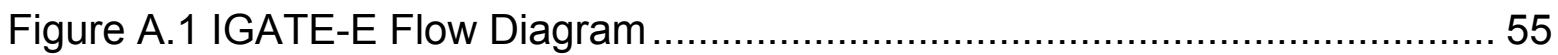

Figure A. 2 Percent of IAC Plants Modeled at the 2-Digit SIC Level ................... 57

Figure A. 3. Magnitude of Model Error as a Function of Number of Standard

Deviations from the Sample Mean .......................................................... 58

Figure A. 4 Magnitude of Model Error as a Function of the Outliers Removed

(Percent of the Total Number of Data Points) .......................................... 59

Figure A. 5 Regression Analysis on SIC 3211...................................... 60

Figure A. 6 IGATE-E@ Main User Interface ........................................... 61

Figure A. 7 Regression Engine Interface ................................................ 61

Figure A. 8 IGATE-E@ Model Results for All Manufacturing Sectors (SIC 20-39)

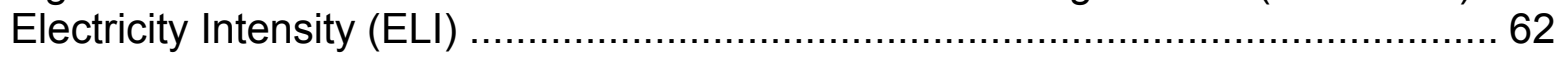

Figure A. 9 Electricity Consumption versus product sales in Dollar.................... 63 
Figure A. 10 SIC 2210-2299 (All Textile Mill Industries) Electrical Energy Intensity.

Figure A. 11 SIC 2210-2299 (Sample Textile Mill Industries) Electrical Energy Consumption as a Function of Products Sales.

Figure A. 12 Comparison of Modeled Electrical Energy Versus EIA-MECS 2011

Published Data (Bottom up Approach). 64 Figure A. 14 Geospatial Representation of Flat Glass Plants (SIC 3211) in US Map using MATLAB Mapping Function. 66

Figure B. 1 Genetic Algorithm (GA) Description. ............................................. 68

Figure B. 2 PU load curve for SIC 32 by GA ................................................ 69

Figure B. 3 Load curves for high load factor and low load factor.......................... 69

Figure B. 4. Example Daily Load Curve for an Iron Foundry............................. 70

Figure B. 5 Process Flow diagram for SIC 3211 (Flat Glass) ............................. 71

Figure B. 6 Graphical Representation for SIC 20 and SIC 22 ......................... 72

Figure B. 7 Graphical Representation for SIC 30 and SIC 32 ......................... 73 


\section{LIST OF TABLES}

Table

Table 1.1 Industrial Sector Represented by Two-Digit SIC with Main Processes

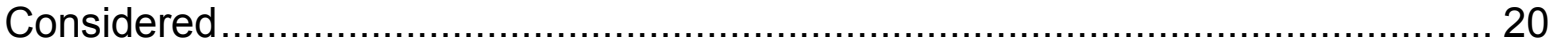

Table 2.1 Electric Loads Breakdown within a Given Manufacturing Sector........... 27

Table 2.2 Criterion Decision Matrix Weighting and Rankings for selecting top 30+

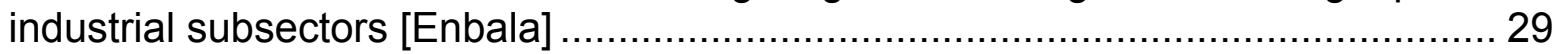

Table 2.3 Participation of resources in different DR products......................... 30

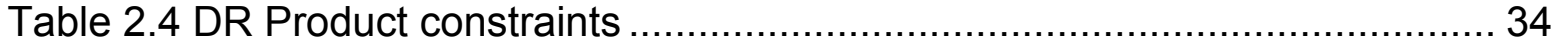

Table 2.5 Resource Ramping Times for Slow and Fast Responses .................... 35

Table 3.1 Summary of Product capabilities, by Balancing Authority Area ............ 46

Table 3.2 Estimated Availability, Peak and Cumulative, and Technical Potential -

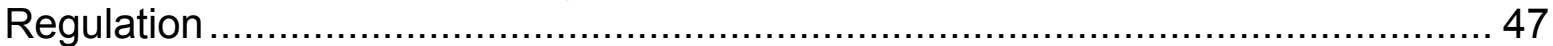

Table 3.3 Estimated Availability, Peak and Cumulative, and Technical Potential -

Flexibility

Table 3.4 Estimated Availability, Peak and Cumulative, and Technical Potential -

Contingency

Table 3.5 Estimated Availability and Technical Potential of Energy and Capacity

Products

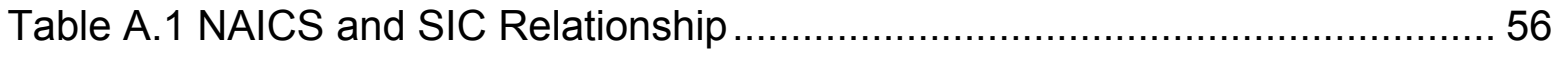

Table B. 1 Process Steps Involved in Flat Glass Manufacturing Industry (SIC 3211)

Table C. 1 Dominating Process \& Load Characterization for the top selected industrial sectors (20-27)

Table C. 2 Dominating Process \& Load Characterization for the top selected industrial sectors (28-33)

Table C. 3 Dominating Process \& Load Characterization for the top selected

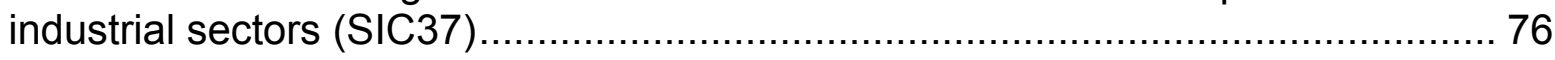

Table C. 4 Acceptability Percentages .................................................... 76

Table C. 5 Controllability Percentages ........................................................ 77

Table C. 6 Sheddability of the Manufacturing Process ................................... 77

Table C. 7 Sheddability of the Device within the Manufacturing Process .............. 78 


\section{EXECUTIVE SUMMARY}

The objective of the Demand Response (DR) and Storage Integration Study is to provide an estimate of the value that DR and storage resources can provide to the United States by participating in energy, capacity, and ancillary services in the year 2020.

A key part of this investigation is the methodology for estimating the capabilities of various load and energy storage technologies to respond to these grid service needs. This report focuses particularly on analyzing the capabilities of industrial loads in providing grid services via DR. As part of this analysis, we construct an expandable framework with the purpose of investigating industrial loads and industrial processes within the Western Interconnect (WI) before expanding to the entire United States. The Western Interconnect, Eastern Interconnect, and Texas Interconnect are the three synchronous alternating current networks in the United States; all areas within an interconnect are electrically linked during normal operation.

Table ES-1 shows the breakdown of Sectorial Electrical Energy Consumption per Region within Western Interconnect (WI) in 1,000 GWH/yr for year 2012 [DOE-EIA 2012]. As can be seen, the total electrical energy consumption in WI for industrial, residential, and commercial sectors is $657,000 \mathrm{GWH} /$ year. Also, the table shows that the Industrial sector in the $\mathrm{WI}$ region represents only $24 \%$ of the total electrical energy consumption in this region. This should explain the reasons for relatively low potential of DR products obtained from this study compared to Residential and Commercial sector (R\&C) analysis (Daniel J. Olsen, et al. 2013).

Table ES-1 Breakdown of Electrical Energy Consumption by Sector within the Four Regions of the Western Interconnect (WI) - (Units: $1000 \mathrm{GWH} / \mathrm{yr}$ ) [EIA-DOE 2012 Data]

\begin{tabular}{|l|c|c|c|c|c|}
\hline \multicolumn{1}{|c|}{ Description } & Southwest & California & Northwest & Rockies & Total \\
\hline Industrial Sector & 23 & 46 & 69 & 17 & 154 \\
\hline $\begin{array}{l}\text { Residential and Commercial (R\&C) } \\
\text { Sectors }\end{array}$ & 99 & 206 & 155 & 44 & 503 \\
\hline $\begin{array}{l}\text { Total Electrical Energy Consumption per } \\
\text { WI Region (1000 GWH/yr) }\end{array}$ & 122 & 251 & 223 & 61 & 657 \\
\hline Percent per WI Region (Industrial) & $19 \%$ & $18 \%$ & $31 \%$ & $28 \%$ & $24 \%$ \\
\hline Percent per WI Region (R\&C) & $81 \%$ & $82 \%$ & $69 \%$ & $72 \%$ & $76 \%$ \\
\hline
\end{tabular}

In general, the industrial sector consists of 20 two digit SIC sectors (representing SIC 20 to SIC 39). Please refer to Table A.1, Appendix A for more details. It should be mentioned that we have not included the following six industrial sectors SICs $(21,34,35,36,38$, and 39) in this analysis (out of 20 industrial sectors). This is either due to limited impact of these sectors in WI region as in the case of SIC 21 where very few industries in this sector exists or due to limited published and reliable information related to the manufacturing process energy consumption. These six sectors represent about $7 \%$ of the total electrical energy consumption in $\mathrm{WI}$ zone. On the other hand, the remaining 14 sectors analyzed represent about $17 \%$ of the total electrical energy consumption in WI zone as shown in Figure ES-1. 


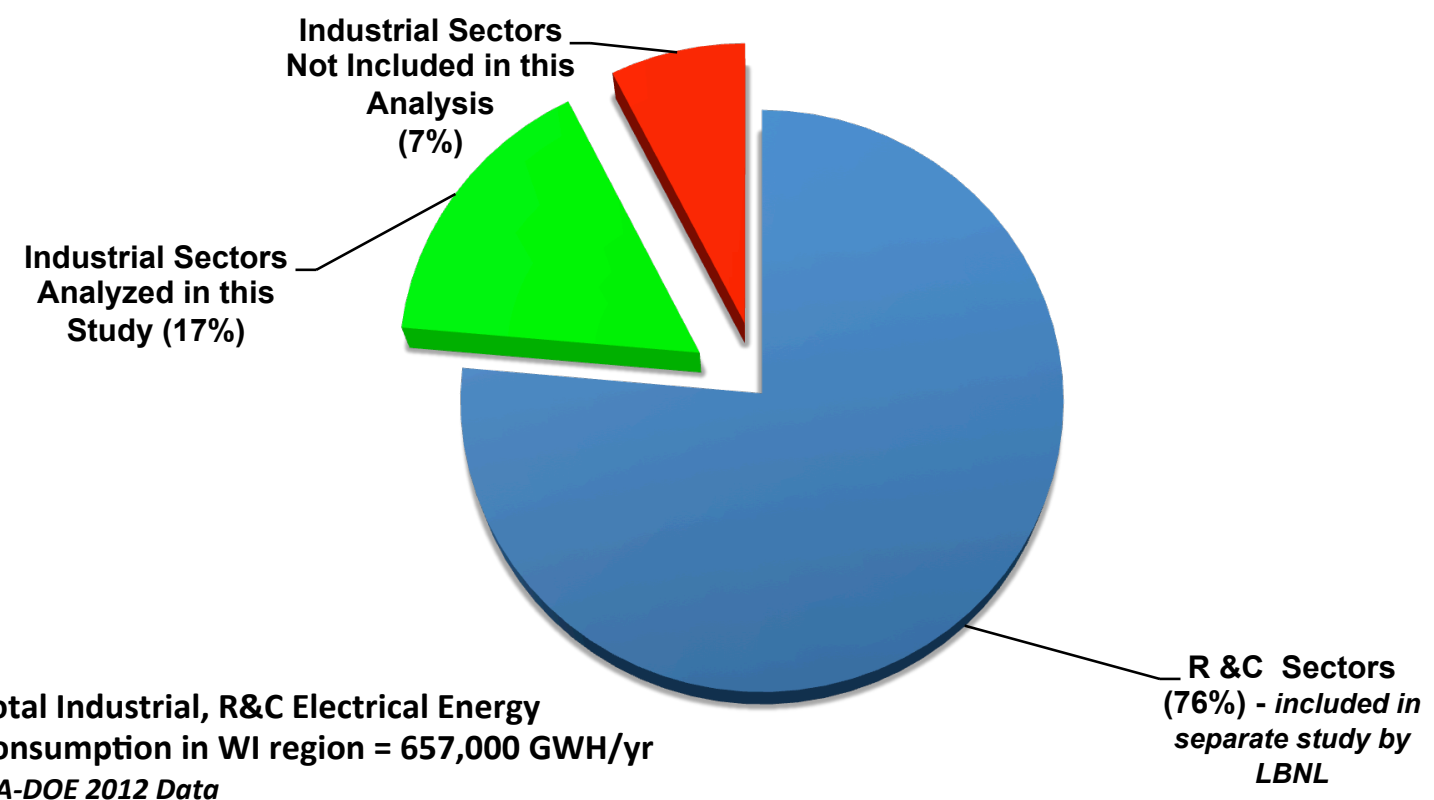

EIA-DOE 2012 Data

LBNL

\section{Figure ES-1 Breakdown of Industrial, Residential, and Commercial (R\&C) Energy Consumption in WI Region (DOE-EIA 2012].}

In this report, industrial load resources that can provide DR to the grid are estimated at the hourly resolution; therefore, load capabilities are estimated at each hour. Load capabilities are disaggregated by end-use, balancing authority area (BAA), and market product for demand response. The assumed DR products are described in Table ES-2. This report does not presume to estimate precisely the amount of load available to respond to a given product in a given hour in the year 2020; rather, this report presents the results of an initial estimation effort based on available information, and forms a general framework to refine these estimates as more or better data emerge.

Table ES-2 - Demand Response (DR) Product Characteristics (Courtesy LBNL)

\begin{tabular}{|l|l|l|l|l|l|}
\hline \multicolumn{2}{|c|}{ DR Products } & \multicolumn{3}{c|}{ Physical Requirements } \\
\hline $\begin{array}{l}\text { DR Product } \\
\text { Type }\end{array}$ & General Description & $\begin{array}{l}\text { How fast } \\
\text { to respond }\end{array}$ & $\begin{array}{l}\text { Length of } \\
\text { response }\end{array}$ & $\begin{array}{l}\text { Time to fully } \\
\text { respond }\end{array}$ & How often called \\
\hline Regulation & $\begin{array}{l}\text { Response to random } \\
\text { unscheduled deviations in } \\
\text { scheduled net load } \\
\text { (bidirectional) }\end{array}$ & 30 seconds & $\begin{array}{l}\text { Energy } \\
\text { neutral in 15 } \\
\text { minutes }\end{array}$ & 5 minutes & $\begin{array}{l}\text { Continuous within } \\
\text { specified bid } \\
\text { period }\end{array}$ \\
\hline Flexibility & $\begin{array}{l}\text { Additional load-following } \\
\text { reserve for large un- } \\
\text { forecasted wind/solar } \\
\text { ramps } \\
\text { (bidirectional) }\end{array}$ & 5 minutes & 1 hour & 20 minutes & $\begin{array}{l}\text { Continuous within } \\
\text { specified bid } \\
\text { period }\end{array}$ \\
\hline Contingency & $\begin{array}{l}\text { Rapid and immediate } \\
\text { response to a loss in supply }\end{array}$ & 1 minute & $\leq 30$ minutes & $\leq 10$ minutes & \begin{tabular}{l}
$\leq$ Once per day \\
\hline Energy
\end{tabular} \\
\hline $\begin{array}{l}\text { Shed or shift energy } \\
\text { consumption over time }\end{array}$ & 5 minutes & $\geq 1$ hour & 10 minutes & $\begin{array}{l}1-2 \text { times per day } \\
\text { with 4-8 hour } \\
\text { notification }\end{array}$ \\
\hline Capacity & $\begin{array}{l}\text { Ability to serve as an } \\
\text { alternative to generation }\end{array}$ & Top 20 hours coincident with balancing authority area system peak \\
\hline
\end{tabular}


End-uses (represented by dominating manufacturing processes within each industrial sector) are selected for inclusion in the study based on the magnitude of their electrical demand (their "load"), and their ability to control their demand in response to the needs of the electrical grid. All available data on magnitude and the pattern of various end-uses are gathered and processed in order to predict hourly load profiles for the year 2020: one for each combination of end-use and balancing authority area. Ultimately, fourteen industrial sectors are selected for inclusion, based on their significant share of total load and their likelihood of having demand response enabling controls systems by 2020. Detailed analyses for the selection of these top industrial sectors are shown in Appendix A. These end uses span the dominating manufacturing processes in these industrial sectors as shown in Table ES-3. In addition to these end-uses, many types of commercial, residential, municipal, and industrial non-manufacturing loads are potential demand response providers (Daniel J. Olsen, et al. 2013).

Table ES-3 Industrial Sectors Analyzed as Represented by Two-Digit SIC with Main Manufacturing Processes Considered [Brown, H.]

\begin{tabular}{|c|c|c|}
\hline $\begin{array}{l}\text { Industrial } \\
\text { Sector } \\
\text { SIC }\end{array}$ & Description & $\begin{array}{c}\text { Dominating } \\
\text { Manufacturing Processes }\end{array}$ \\
\hline 20 & Food And Kindred Products & Packaging, Chiller \\
\hline 22,23 & Textile Mill Products, and Apparel & Wrapping, Weaving \\
\hline 24,25 & Lumber And Wood Products, Furniture and Fixtures & Sawing, Planning \\
\hline 26 & Paper And Allied Products & Chipper, Dewatering Press \\
\hline 27,28 & $\begin{array}{l}\text { Printing and Publishing, Chemicals And Allied } \\
\text { Products }\end{array}$ & Electrolysis, Compressor, Grinding \\
\hline 29 & Petroleum Refining And Related Industries & Catalytic Cracking \\
\hline 30,31 & $\begin{array}{l}\text { Rubber And Miscellaneous Plastics and Leather } \\
\text { Products }\end{array}$ & Mixing, Milling \\
\hline 32 & Stone, Clay, Glass, And Concrete Products & Electric Furnace, Crushing \\
\hline 33 & Primary Metal Industries & Crushing and Classifying \\
\hline 37 & Transportation Equipment & Metal Cutting, Final Assembly \\
\hline
\end{tabular}

To determine what fraction of these loads can respond to each of the products in each hour of the year, three flexibility filters are established:

- Sheddability refers to the percentage of the load for a given end-use which can be shed by a typical demand response strategy, assuming adequate communications, controls and incentives exist

- Controllability refers to the percentage of load associated with equipment that has the communications and controls in place necessary to achieve load sheds/shifts.

- Acceptability refers to the percentage of load associated with equipment or services that are willing to accept the reduced level of service in a demand response event, in exchange for financial incentives.

Applying the flexibility filters to a generic set of industrial load profiles leads to five distinct demand response availability profiles with hourly resolution (one for each product) for every combination of end-use and balancing authority area (BAA). With these hourly profiles, the load response characteristics such as response times, ramp rates, minimum and maximum 
up times, and allowable call frequency are provided as analogous to generators. The response time is the time between when a product signal is sent and when the end-use begins generating (shedding load) and the ramp rate describes the rate that load will changed. Minimum and maximum up-times refer to limits on the length of sheds, and the call frequency determines how often sheds can be called. The process of integration of these end-uses into a production cost model and an analysis of their behavior in a test system under various scenarios will be described in another report in this series (Hummon et al. 2013).

The results from model runs in a full Western Interconnect model will be described in a subsequent report. These efforts estimate the potential and economic incentives for load to participate in capacity, energy, and ancillary services markets; however, they do not cover the regulatory and market aspects of load participation. These issues are discussed in a recently released report developed as part of this project, Market and Policy Barriers for Demand Response Providing Ancillary Services in U.S. Markets (Cappers et al. 2013).

Although this study produces an estimation of both the hourly realizable potential and the technical potential for DR to participate in ancillary services in 2020, additional work is needed to fully interpret our technical potential. For example, a detailed sensitivity analysis between various design and input decisions on model outcomes is still needed. Moreover, new high-resolution, end-use, load data are becoming available at a rapid pace. Limitations and uncertainty in the present study will greatly reduce as we incorporate such data.

Finally, there have been few large-scale assessments of the capabilities of loads to respond to various DR products other than for shaving peak loads. Future work with potential to expand on the conclusions of this report includes:

- Expansion to full industrial sectors, subsectors, and manufacturing processes.

- Widespread testing and demonstrations of DR strategies with end-users, in order to assess customer acceptance and actual potential for DR, and

- Economic analyses as it relates to the relationship of incentive payments and the amount of load that customers are willing to provide.

\section{Summary of Results}

The results of this study are provided in Table ES-4. The analysis considers the amount of demand response availability for each type of demand response product in the aforementioned 14 industrial sectors. Two case scenarios are developed in the analysis; Scenario 1 represents the estimated availability based on most recent data from DOE EIAMECS. Scenario 2 represents the estimated availability considering full acceptability by industry by 2020 . Scenario 2 can be referred to as "Technical Potential".

The technical potential for responding load can be estimated by assuming that all end-uses are $100 \%$ controllable and willing to respond to grid needs at all times. In this case, there is a maximum of $572 \mathrm{MW}$ available for Regulation, $2.49 \mathrm{GW}$ available for Flexibility, $2.44 \mathrm{GW}$ available for Contingency, $2.54 \mathrm{GW}$ available for Energy, and $2.72 \mathrm{GW}$ available for Capacity. These numbers represent roughly a five-fold increase in availability compared to the estimated realizable potential. The estimated availability and technical potential are compared in Table ES-4. 
Table ES-4 Total Western Interconnect DR Product Availability - Two Scenarios

\begin{tabular}{|l|c|c|}
\hline \multicolumn{1}{|c|}{ Product } & $\begin{array}{c}\text { Scenario 1* } \\
\text { Estimated Availability } \\
\text { (relative to total load) }\end{array}$ & $\begin{array}{c}\text { Scenario 2 } \\
\text { Technical Potential } \\
\text { (relative to total load) }\end{array}$ \\
\hline Regulation & $111-176 \mathrm{MW}(0.7 \%-0.8 \%)$ & $339-572 \mathrm{MW} \quad(2.3 \%-2.7 \%)$ \\
\hline Flexibility & $439-703 \mathrm{MW}(2.9 \%-3.5 \%)$ & $1,475-2,491 \mathrm{MW}(10.2 \%-11.7 \%)$ \\
\hline Contingency & $427-686 \mathrm{MW}(2.8 \%-3.4 \%)$ & $1,443-2,443 \mathrm{MW}(10 \%-11.5 \%)$ \\
\hline Energy Shift & $287-531 \mathrm{MW}(2.1 \%-2.2 \%)$ & $1,272-2,540 \mathrm{MW}(10.1 \%-10.4 \%)$ \\
\hline Capacity & $303-563 \mathrm{MW}(2.3 \%-2.4 \%)$ & $1,361-2,721 \mathrm{MW}(10.8 \%-11.2 \%)$ \\
\hline${ }^{*}$ Based on most recent updated DOE EIA-MECS acceptability factors[DOE-EIA MECS-2006] \\
\hline
\end{tabular}

Based on the assumptions made about the magnitude and behavior of the selected enduses within the Western Interconnect (Scenario 1), the demand response resources can contribute as much as $176 \mathrm{MW}$ available for Regulation, $703 \mathrm{MW}$ available for Flexibility, $686 \mathrm{MW}$ available for Contingency, $531 \mathrm{MW}$ available for Energy, and $563 \mathrm{MW}$ available for Capacity. Expressed as a fraction of total Western Interconnect load, these values represent up to $0.8 \%$ of load for Regulation, 3.5\% for Flexibility, 3.4\% for Contingency, $2.2 \%$ for Energy, and $2.4 \%$ for Capacity. The interpretation of the Energy and Capacity values differs from those of the ancillary services. For each BAA, the Energy availability is combined with the maximum event durations for each resource to calculate the largest single-event energy shift that can be achieved. The availability of Capacity from DR resources is only relevant during the 20 hours of highest net load (total demand - solar wind) for each BAA; the minimum availability during these hours is the Capacity value for that BAA. The range of values for each product is shown in Figures ES-2 and ES-3 for both case scenarios described earlier. For each DR product, the range of total product availability within the Western Interconnect is calculated by summing the availability of each resource in each BAA. Most of the total product availability is in a somewhat narrow range (the blue boxes, representing the range between the first and third quartile). Also, the peak availability is represented by whiskers for each product (representing the minimum and maximum values).

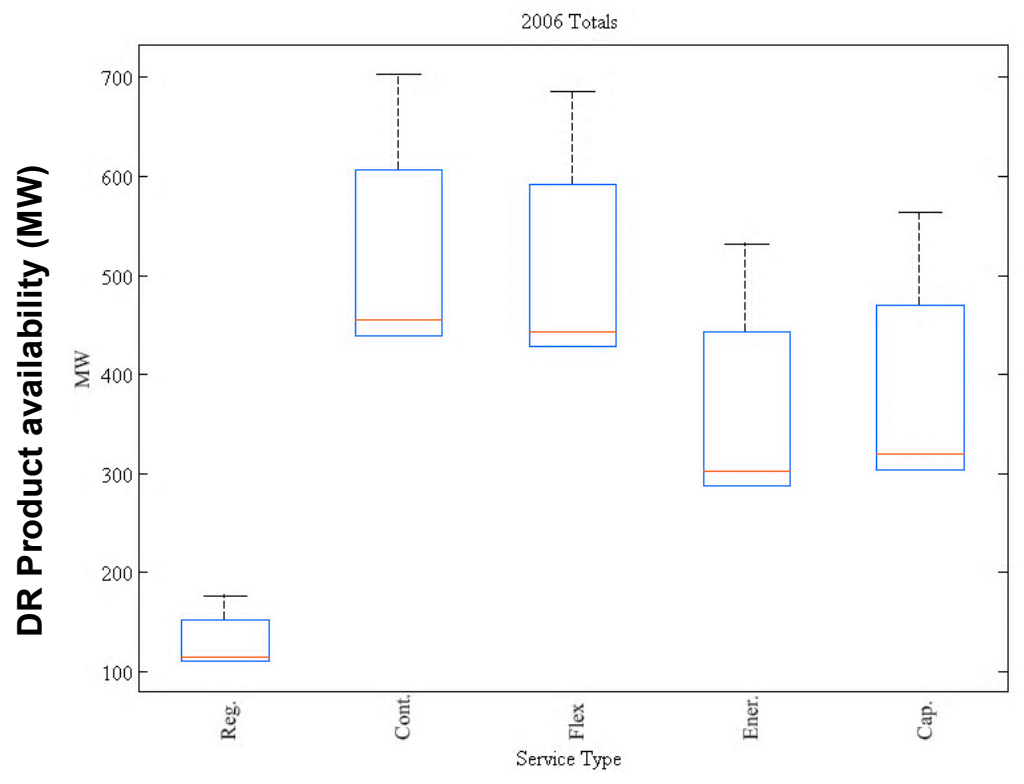

Figure ES-2 DR Product availability ranges in MW for Scenario 1 


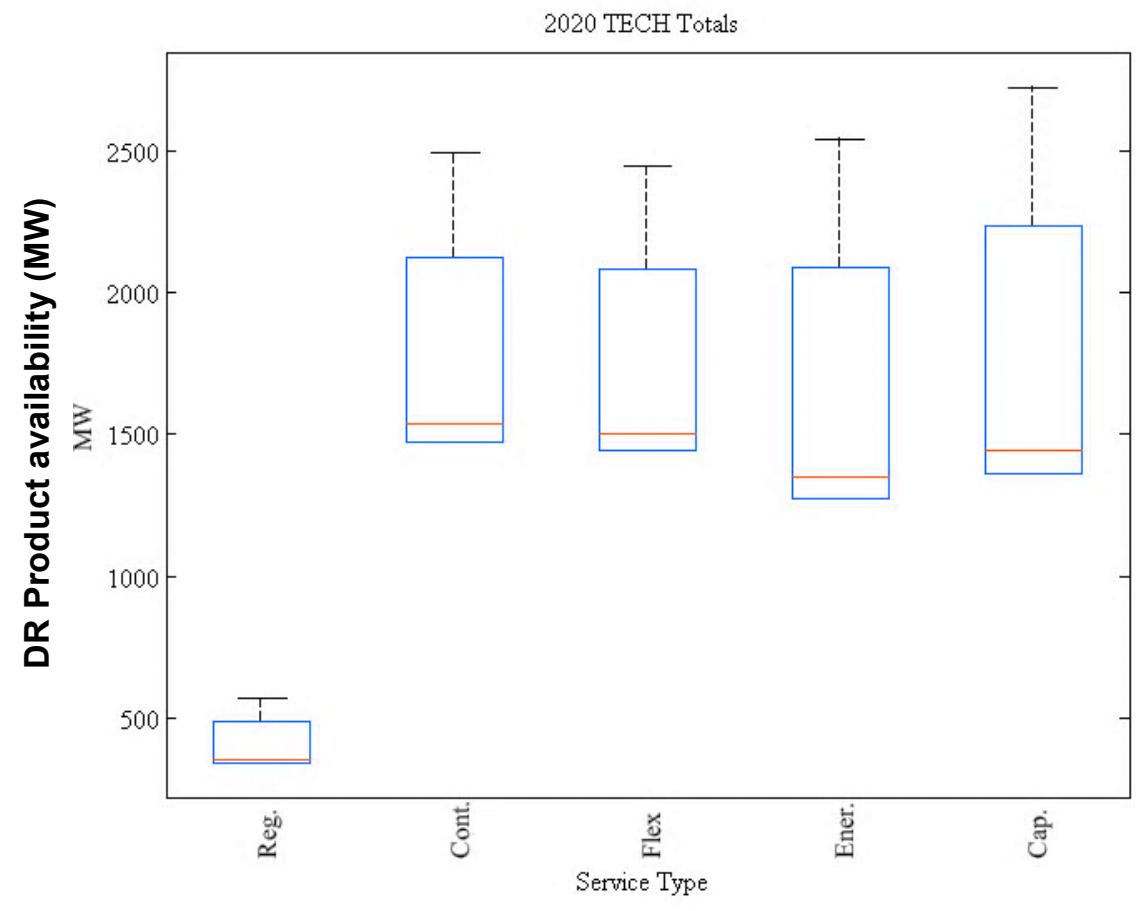

Figure ES-3: DR Product availability ranges in MW for Scenario 2 


\section{Chapter 1 INTRODUCTION}

\subsection{Background}

The growth of renewable generation assets across the U.S. has led to an increased concern related to the projected need for more reliability services within the transmission system. This is particularly true in areas where renewable generation has increased or is inspected to increase to significant levels in relation to the load. As an example, a study performed for the California Energy Commission by KEMA found that as California tries to meet the 2020 Renewable Portfolio Standard of 33\% renewable energy resource, a significant need for flexible resources such as energy storage will become vital (Masiello 2010). Depending on the specific need, demand response may play a major role in providing this flexibility or contributing to the required ancillary services.

A recent workshop held by the Department of Energy in 2011 determined that planning for ancillary services provided by loads requires a much more detailed understanding of the available load and market potential of that load (DOE 2011). The needed analysis covers multiple objectives: (1) see if the available demand response will meet future market needs with the expected increase in renewable generation (2) examine the concerns of market saturation for demand response resources, and (3) find the potential value proposition for the demand response resources. In developing the analysis and constructing the models to derive answers to these questions, the quantity of available demand response by resource is a vital input.

Historically in estimating the demand response resource, evaluations have always been conducted with "top down" approaches where global assumptions on loads and consumption from EIA (Energy Information Agency) and other statistics are utilized to coarsely estimate large geographic areas. As a result, the evaluation process for demand response for the industrial sector has been largely ignored or estimated across the U.S. as a whole, but not broken down into regional analysis capabilities. This is largely due to the uniqueness of manufacturing processes and the sparseness of the industrial plants across the U.S.

In this report, a framework is discussed for the development of availability profiles that can provide more regional understanding and potentially be inserted into analysis software for further study. The developed framework utilizes a number of different informational resources, algorithms, and real-world measurements to perform a "bottom-up" approach in the development of a new database with representation of the potential demand response resource in the industrial sector across the U.S. This tool houses statistical values of energy and demand response (DR) potential by industrial plant and geospatially locates the information for aggregation for different territories without proprietary information. This report will discuss this framework and the analyzed quantities of demand response for Western Interconnect in support of evaluation of the cost production modeling.

\subsection{Overall Approach}

The framework for this report and development of industrial demand response potential estimations consist of a number of steps including validation of each step as possible. The 
overall process of data sets development is shown in Figure 1.1. This can be summarized into the following five major components:

1. Determination of each industrial plant's energy consumption with geospatial linkage (Steps 1-3)

2. Development of process breakdown into process steps and generalized load curves (Steps 4-10)

3. Determination of the amount of resource flexibility and its association with demand response potential at the level of industrial process

4. Calibration of load curves (Steps 11-12)

5. Compiling of WI data (Steps 13-14) to capture an estimated potential demand response under different case scenarios.

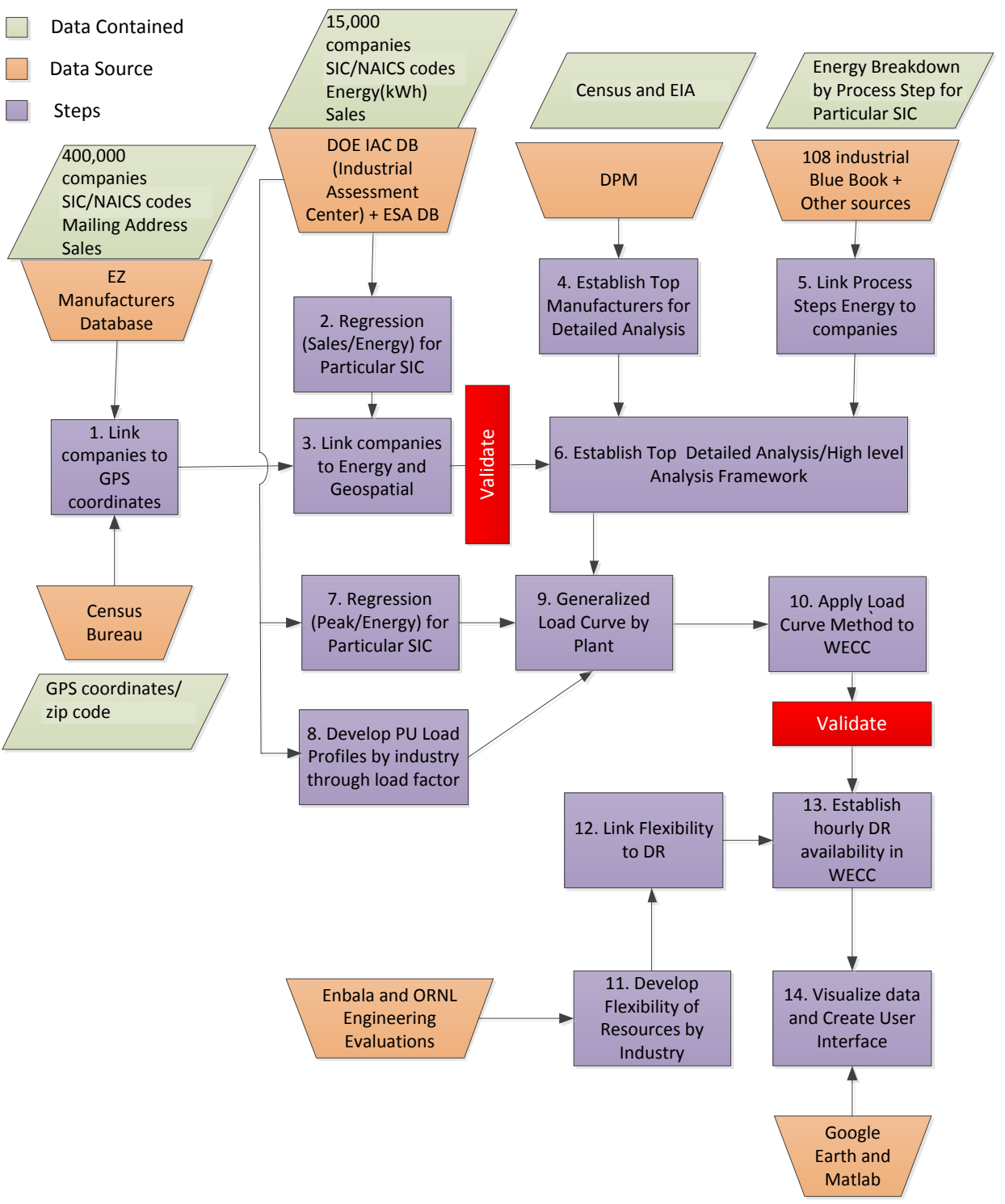

Figure 1.1 Overall Approach 
End-uses (represented by dominating manufacturing processes within each industrial sector) are selected for inclusion in the study based on the magnitude of their electrical demand (their "load"), and their ability to control their demand in response to the needs of the electrical grid.

All available data on magnitude and the pattern of various end-uses are gathered and processed in order to predict hourly load profiles for the year 2020: one for each combination of end-use and balancing authority area. Ultimately, fourteen industrial sectors are selected for inclusion, based on their significant share of total load and their likelihood of having demand response enabling controls systems by 2020.

Detailed analyses for the selection of these top industrial sectors are shown in Appendix A. These end uses span the dominating manufacturing processes in these industrial sectors as shown in Table 1.1 In addition to these end-uses, many types of commercial, residential, municipal, and industrial non-manufacturing loads are potential demand response providers [Daniel J. Olsen, et al. 2013].

Table 1.1 Industrial Sector Represented by Two-Digit SIC with Main Processes Considered

\begin{tabular}{|cll|}
\hline SIC & \multicolumn{1}{c|}{ Description } & \multicolumn{1}{c|}{$\begin{array}{c}\text { Dominating } \\
\text { Manufacturing Processes }\end{array}$} \\
\hline $\mathbf{2 0}$ & Food And Kindred Products & Packaging, Chiller \\
\hline $\mathbf{2 2 , 2 3}$ & Textile Mill Products, and Apparel & Wrapping, Weaving \\
\hline $\mathbf{2 4 , 2 5}$ & Lumber And Wood Products, Furniture and Fixtures & Sawing, Planning \\
\hline $\mathbf{2 6}$ & Paper And Allied Products & Chipper, Dewatering Press \\
\hline $\mathbf{2 7}$, & Printing and Publishing, Chemicals And Allied & Electrolysis, Compressor, \\
$\mathbf{2 8}$ & Products & Grinding \\
\hline $\mathbf{2 9}$ & Petroleum Refining And Related Industries & Catalytic Cracking \\
\hline $\mathbf{3 0}$ & Rubber And Miscellaneous Plastics and Leather & Mixing, Milling \\
$\mathbf{3 1}$ & Products & \\
\hline $\mathbf{3 2}$ & Stone, Clay, Glass, And Concrete Products & Electric Furnace, Crushing \\
\hline $\mathbf{3 3}$ & Primary Metal Industries & Crushing and Classifying \\
\hline $\mathbf{3 7}$ & Transportation Equipment & Metal Cutting, Final Assembly \\
\hline
\end{tabular}

The availability of loads is disaggregated by 36 balancing authority areas (BAAs) within the Western Interconnect. These areas are shown in Figure 1.2(three small BAAs in Washington are omitted from the map: CHPD, DOPD, and GCPD). BAA abbreviations are expanded in the Glossary.

To estimate the magnitude of DR potentially available from a selected end-use at each hour, it is necessary to first estimate the magnitude of end-use loads at each hour. Representative load profiles for each end-use were scaled to match predicted energy consumption for 2020. A full listing of the aggregated load profiles generated, by BAA and resource, can be found in Chapter 3 . 


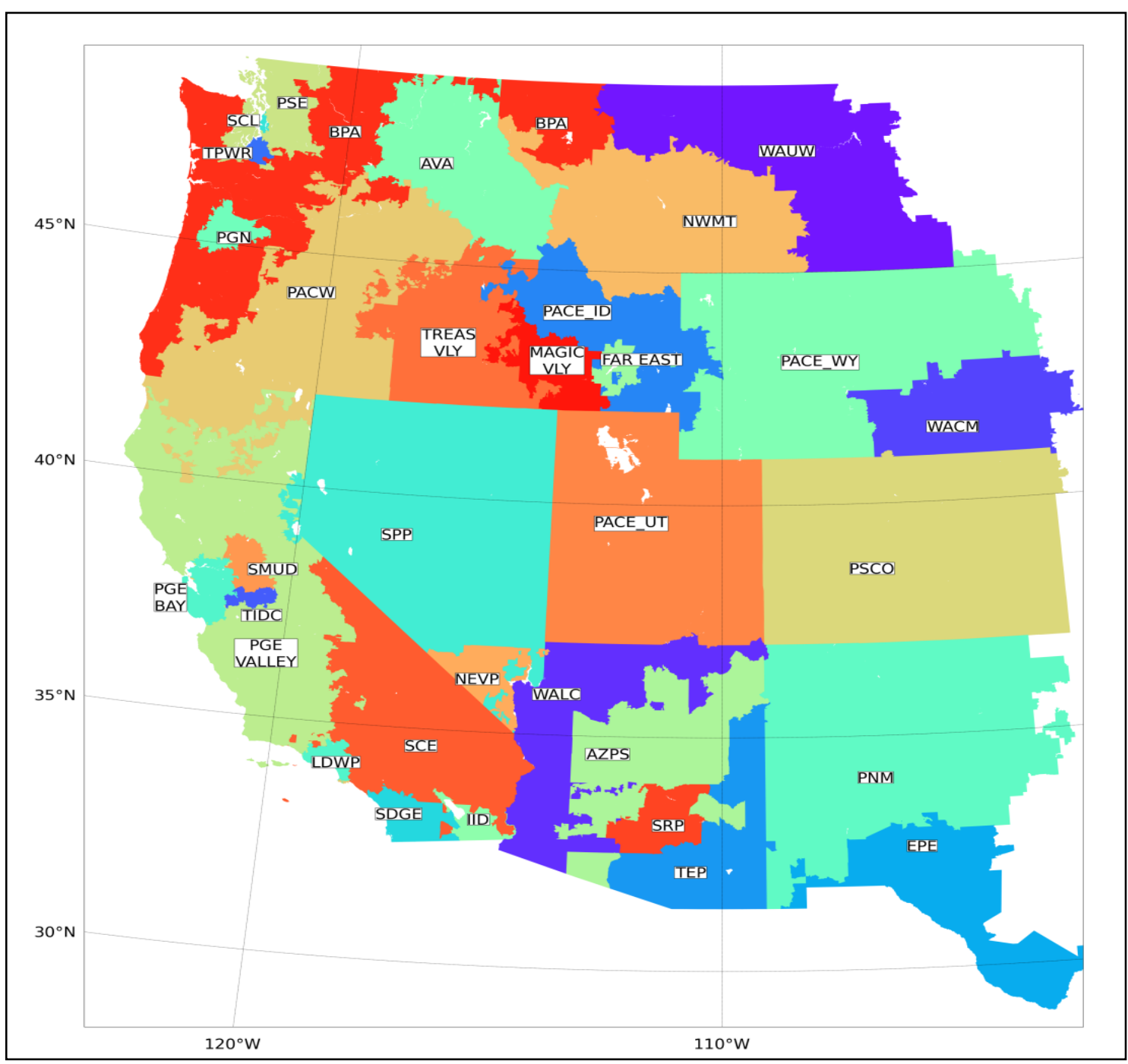

Figure 1.2 Balancing Authority Areas (BAAs). Boundaries are approximate. Courtesy LBNL

\subsection{Report Organization}

The report is organized as follows:

- Chapter 1 describes the background of the project and the overall approach to characterization and estimations.

- Chapter 2 provides a more detailed description of the methodology in the characterization and estimations.

- Chapter 3 describes the results of the analysis.

- Chapter 4 provides conclusions, recommendations, and future work.

- Appendices A-D provides a more rigorous examination of the methodologies described in Chapter 2 and results in Chapter 3 and input data used to develop the DR estimations. 


\section{Chapter 2 METHODOLOGY}

\subsection{Electrical Energy Consumption Estimation by Manufacturing Plant}

Datasets developed by the Department of Energy, other government agencies, and the private sector are numerous and plentiful. Most often the difficulty lies in identification of the appropriate resource of information for use in a project. In this study, several databases were sequestered including the Census Bureau, Industrial Assessment Center Evaluations (IAC), DOE Energy Savings Assessments (ESA), Manufacturing News, Inc. Database $(\mathrm{MNI})$ and others.

As shown in Figure 2.1, the manufacturing plants energy information (mainly small to medium and large size plants) datasets from previous field work were polled using publicly available IAC database and Energy Saving Assessments data (ESA). Plant level energy information included industry types based on SIC (Standard Industrial Classification) and/or NAICS (North American Industry Classification System), energy systems, size of the plants in terms of square footage, number of staff employed, number of operating hours, average peak demand, electrical energy consumption, and product sales. The SIC codes (NAICS codes) classify establishments by their primary activity. The two classification systems introduce difficulties when combining older and newer datasets; data for more than twothirds of all 4-digit SICs will be derivable from the NAICS system, either because the industry is not being changed (other than in code), or because new industries are being defined as subdivisions of old ones.

Manufacturing News, Inc. Database (MNI) is a commercially available database which houses over 300,000 manufacturing plants entries and matches the official count by the US Census Bureau. The MNI database contains information on specific companies such as SIC (NAICS), plant name, type of products, product sales figures, zip code, mailing address, and company contacts. This information was gathered by MNI through phone calls and direct interviews with plants and companies personnel. EIA's 2006 Manufacturing Energy Consumption Survey (MECS - 2006) is a publicly available data on industry energy consumption. EIA's MECS 2010 data contain estimates of the number of establishments, average energy consumption by industry code and average energy costs by key industry code.

The analysis involved performing linear regressions with the available data from the IAC and ESA utilizing the information regarding electricity consumption and peak in relation to the sales of the industries. The derived coefficients of regression for each type of industry as represented by SIC code (captured from IAC DB) were applied to the corresponding SIC in the MNI database where the sales information of each manufacturing plant is utilized to predict the plant level electrical energy consumption associated with this given SIC across the U.S. industrial sector. An example of the regression technique is shown in Figure 2.2 for Flat Glass Industrial subsector (SIC 3211). The entire analytical framework is called IGATE-E@ “Industrial Geospatial Analysis Tool for Industrial Energy Evaluation" [Alkadi 2013]. More detail regarding this analysis can be found in Appendix A. 


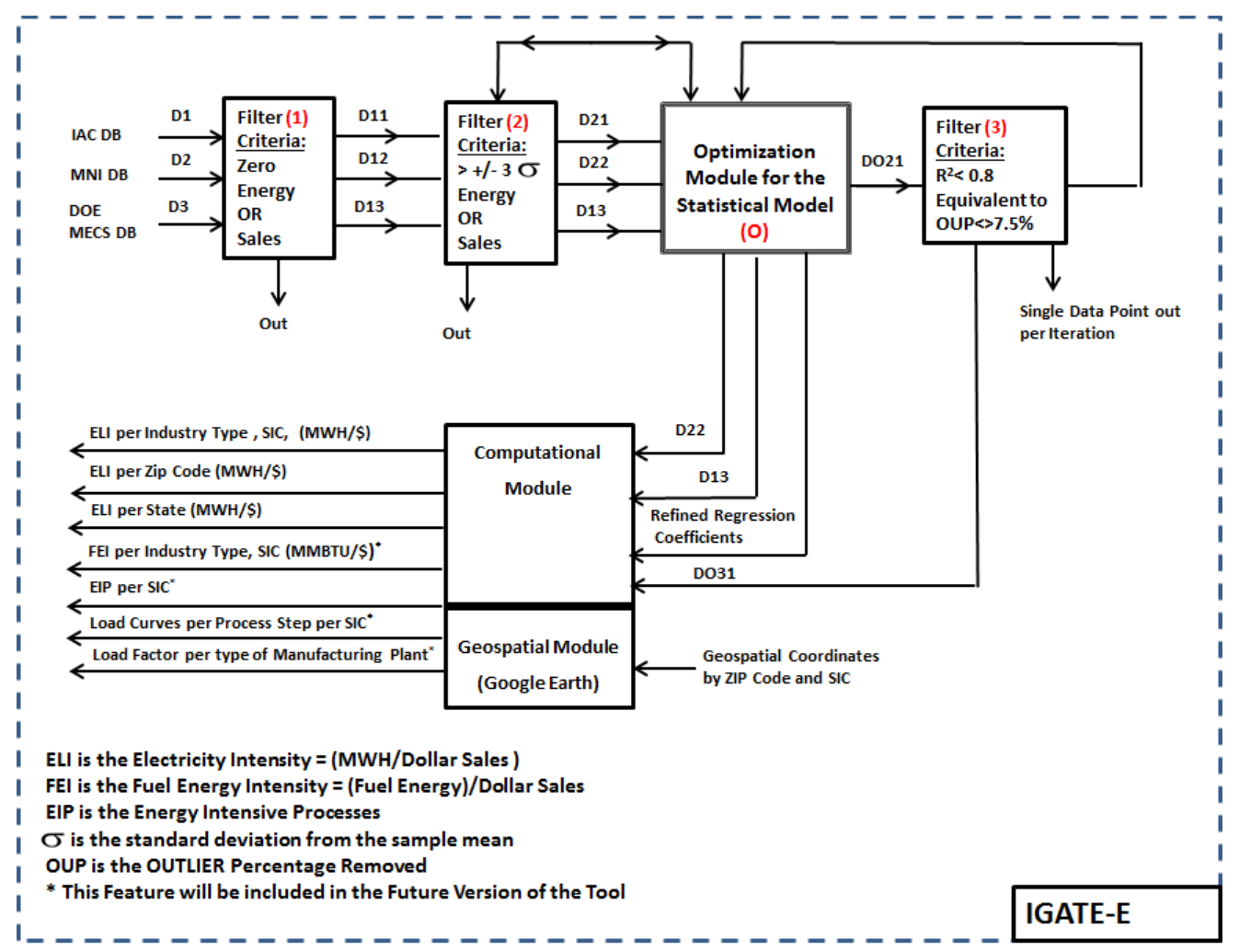

Figure 2.1 Data filtering and flow diagram

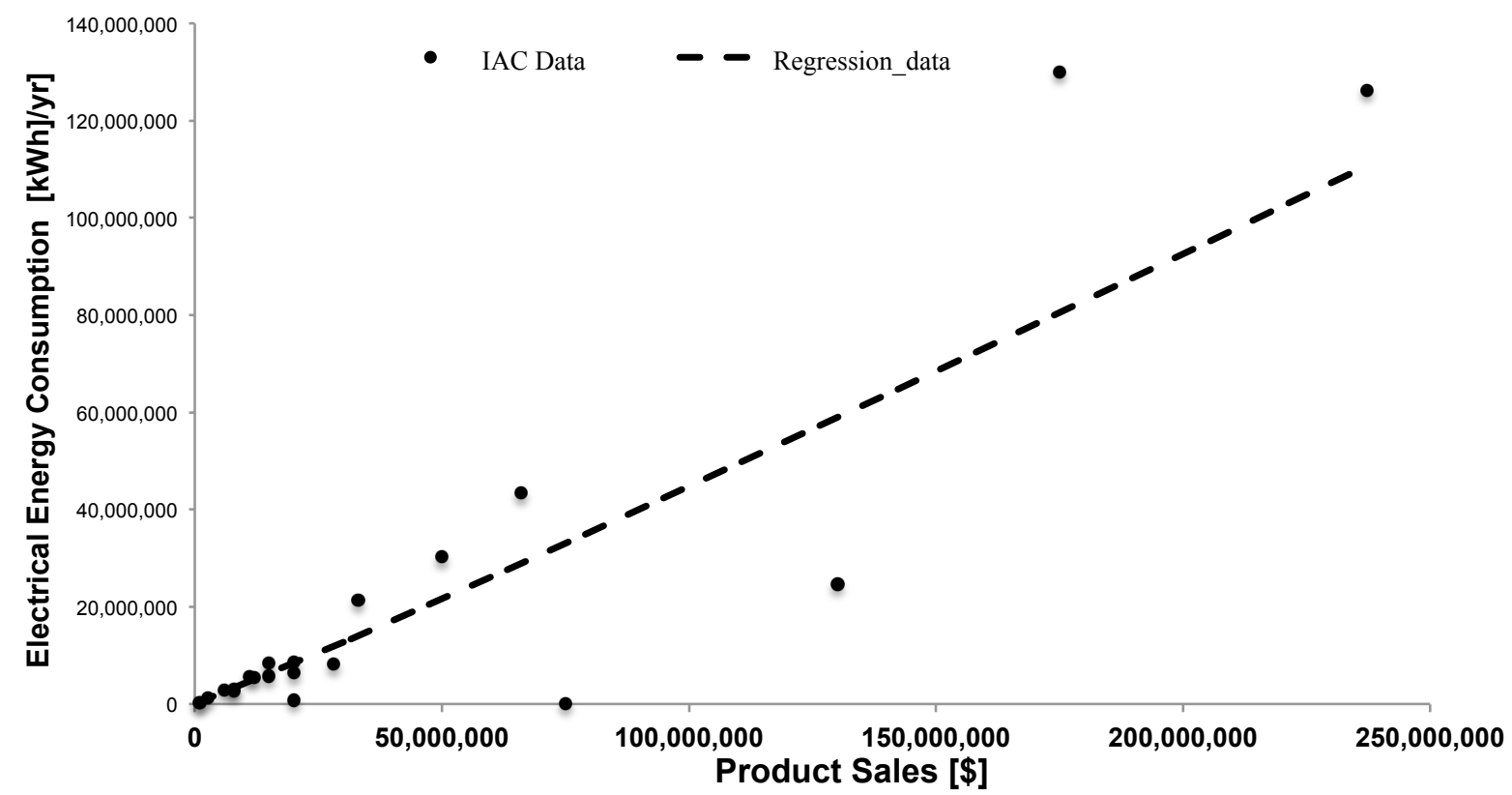

Figure 2.2 Regression Analysis - Flat Glass Industry (SIC 3211) 
The statistical method explained in Appendix A was used to apply data from IAC DB to the population of manufacturing plants $(300,000+)$ in the MNI DB and compare with the published industrial electricity consumption state level data from the DOE's EIA-MECS [Table C7] as shown in Figure 2.3 This chart includes all 50 states, but there is limited space for labeling. As can be seen, the fitted data from the statistical module in most of the cases correlates well with the EIA-MECS published data for the 50 states. Likely, the deviations will tighten up as more information becomes available for the developed methodology. It should be mentioned that the IAC-DB, one of the main data sources for this study is updated on a frequent basis. This will definitely improve the quality of regressions and curve fit for some industrial sectors and the overall validation process.

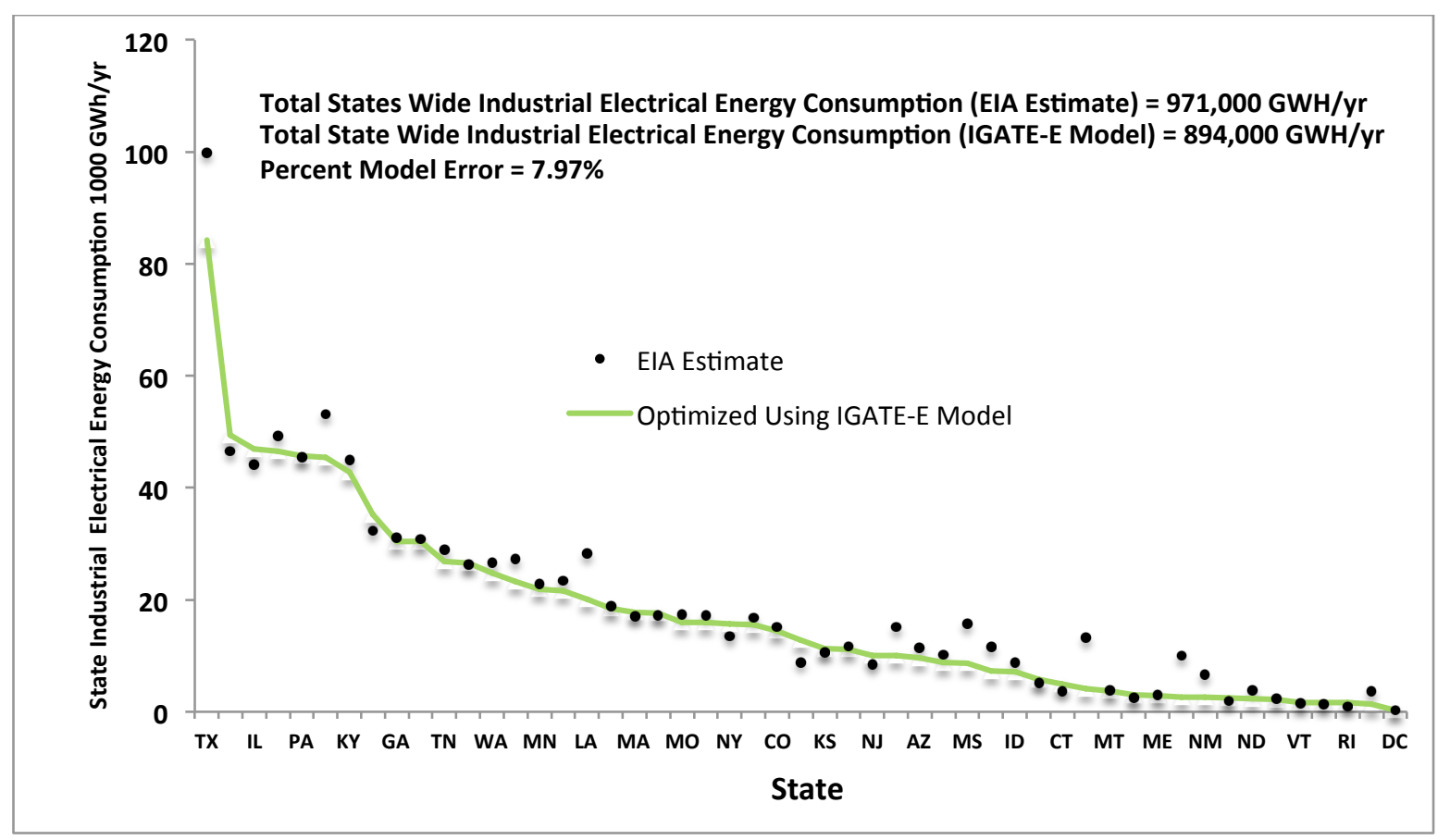

Figure 2.3 Comparison of Modeled Electrical Energy Versus EIA-MECS Published Data [Table C7., 2011] (Using Bottom up Approach)

The same statistical method was also applied to industrial plants located within Western Interconnect (WI). Figure 2.4 shows the total actual electrical energy consumption within each WI zone compared to the estimated total industrial electrical energy consumption in WI Zone using IGATE-E@ framework [Appendix A]. As can be seen in Figure 2.4, the total annual electrical energy consumption from industrial loads has been estimated to be 140 billion $\mathrm{kWh}(140,000 \mathrm{GWH} / \mathrm{yr})$. EIA actual data shows an annual energy consumption of 154 billion $\mathrm{kWh}(154,000 \mathrm{GWH} / \mathrm{yr})$ for in industrial load (EIA 2013). EIA estimates that the industrial load represents $24 \%$ of the total electrical load (EIA 2013) with most of the remaining load allocated to Residential and Commercial (R\&C) sectors as previously mentioned in the executive summary of this report. 


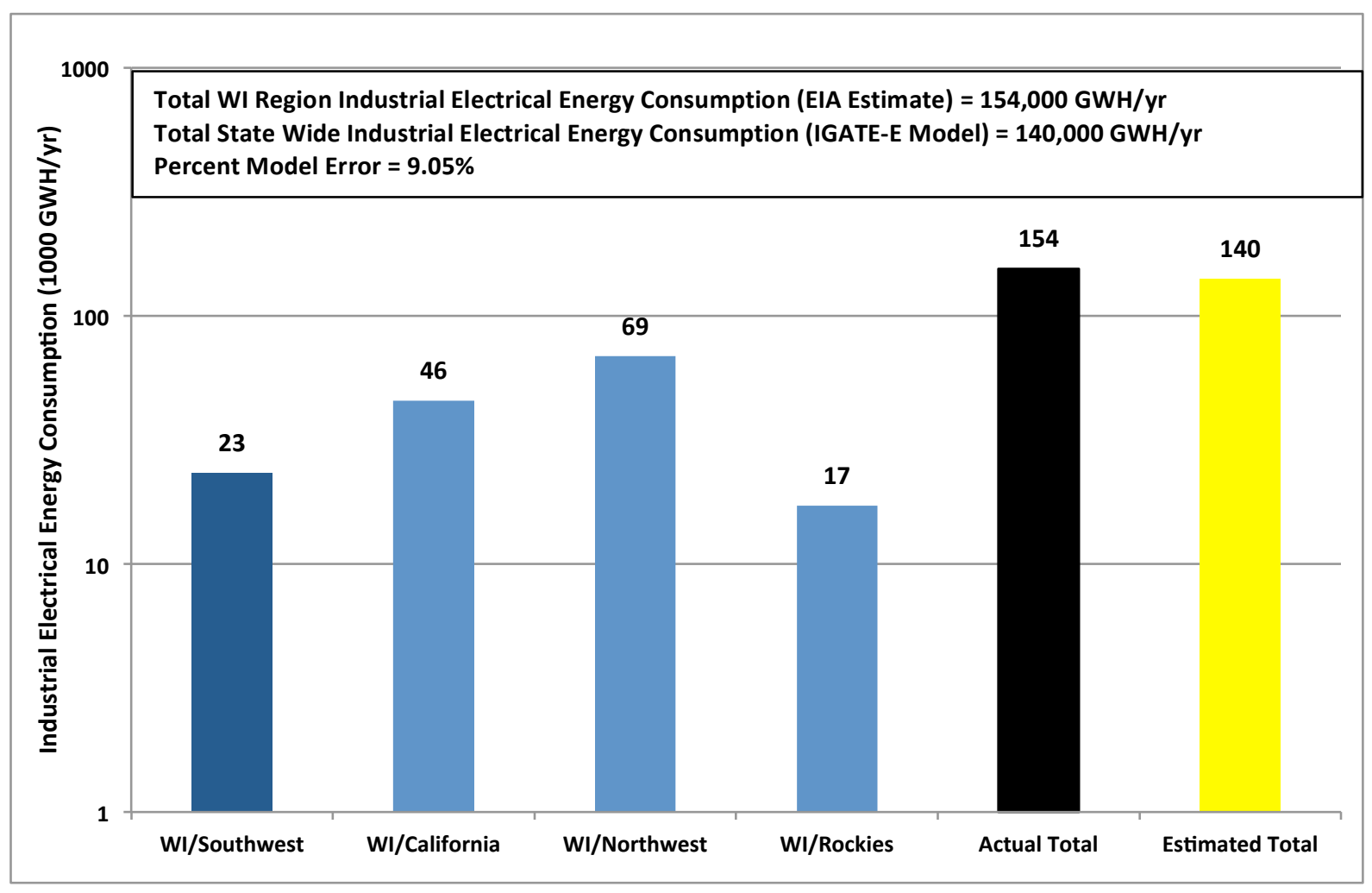

Figure 2.4 Actual (with breakdowns) vs. Estimated Total Industrial Electrical Energy Consumption in WI region - Note: Logarithmic Scale

*DOE-EIA 2012

\subsection{Daily Load Curve Development for Industrial Processes}

The development of load curves for each industrial sector at the plant level is a necessary part of the work for establishing different DR products availability per hour from the respective loads. These load curves were developed in a generic fashion so that each type of industry subsector would have a distinct daily load curve, however, individual plants within the same industry sector were assumed to exhibit the same load profile trend. We reverted to this assumption based on sample experimental studies and due to limited and proprietary information. In developing a signature load curve by each industry type, an attempt has been made to develop a methodology that is expandable across all of the industry subsectors represented by four-digit SICs. The methodology involves the calculation of an average load factor by each industry type and utilizes the genetic algorithms (GA) to create a Per-Unitized (PU) curve that is expandable to plant size based on the yearly electrical energy consumption. The GA method is explained in details in Appendix (B). The load factor for each industry was determined using field data from the IAC database. The IAC database includes data of the peak loads, electrical energy consumption, and operating hours for about 16,000 manufacturing plants affiliated to the major 20 industrial sectors in the US. The operating hours were utilized to scale the electrical energy to a yearly cycle and to create a yearly calculation of load factor (defined as the average electrical energy consumption in $\mathrm{kWh}$ divided by the peak load in a given time period). 
A high load factor means power usage is relatively constant. Low load factor shows that occasionally a high demand is set. To service that peak, capacity is sitting idle for long periods, thereby imposing higher costs on the system. The results of two-digit SIC sector analysis is shown in Figure 2.5.

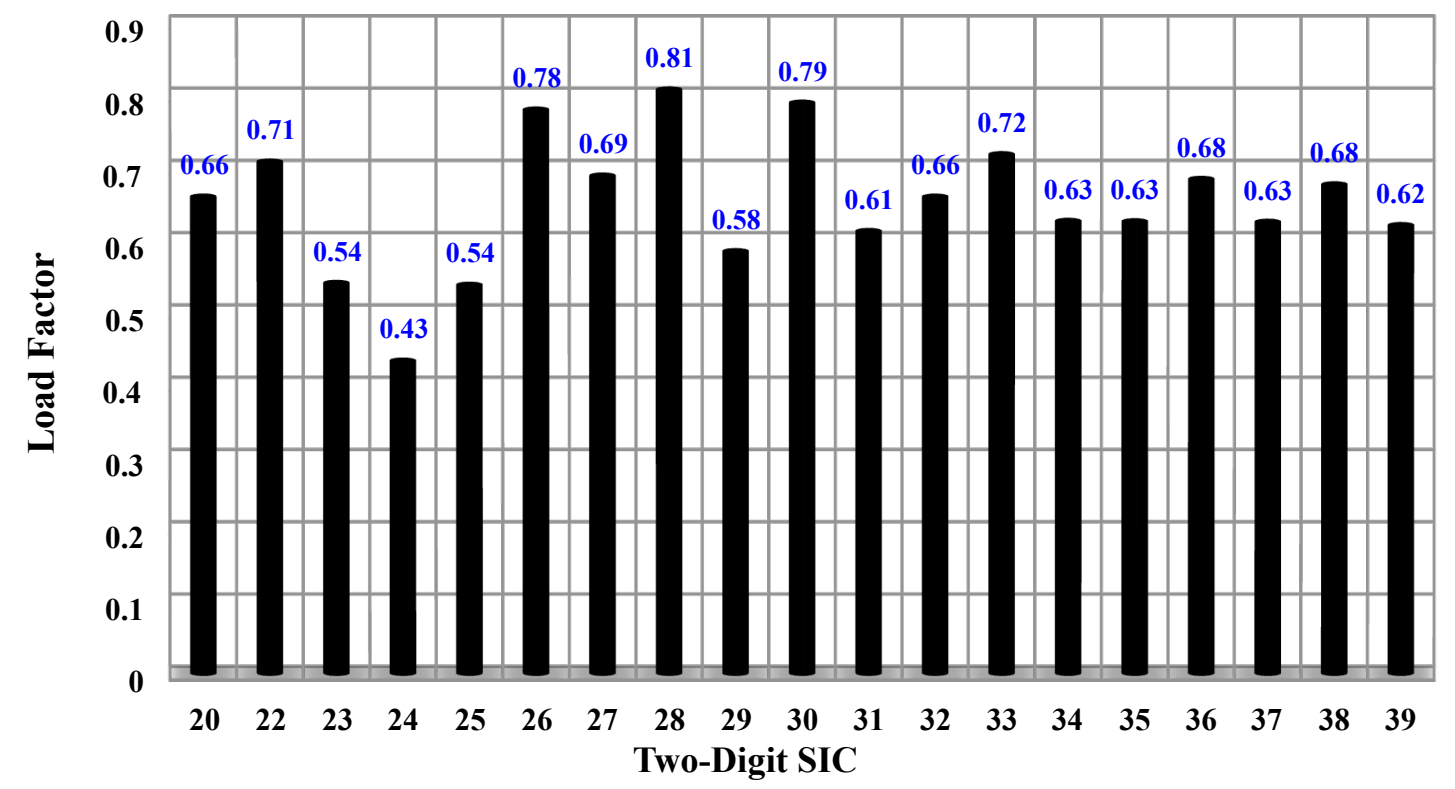

Figure 2.5. Load Factor calculation results based on DOE-IAC Field Data *

${ }^{*}$ Sectors SICs (21, 34, 35, 36, 38, and 39) are not included in the study [Refer to Executive Summary]

Genetic algorithms (GA) were applied to optimize the Per-Unitized (PU) load curve to a specific load factor. The assumption was made that many plants would operate during weekdays at $1 \mathrm{PU}$ in the hours from 9AM to 4PM with a lunch time break. During weekends, the minimum load would be used which also matches the daily non-working hours after 4PM. More discussion of the methodology with examples are provided in Appendix $B$. The developed daily load curve for SIC 32 using the GA method is shown in Figure 2.6. Four digit SIC sector analysis was utilized to develop the load curves for each plant where available regression data is existent. If not available, 2 digit SIC load factor results were used. 


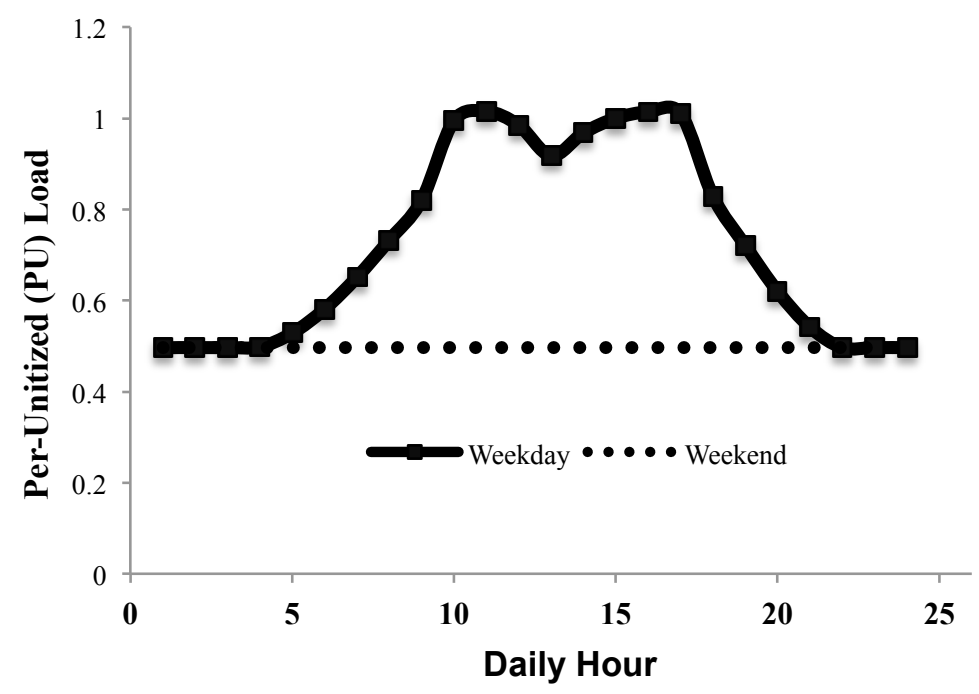

Figure 2.6. Per-Unitized Load Curve for SIC 32 Using Genetic Algorithm (GA)

After development of the daily load profile for a given type of industry (using above approach), each type of industry (consists of several manufacturing processes) was broken down into several process steps. Each process step is a part of the manufacturing plant's requirement to perform some form of useful work.

There are multiple process steps within each type of industry and each process step consists of specific devices functioning in tandem to make a product. Devices are defined as the terminal unit of the process step that consumes the electrical energy. Often, a process step comprises of a collection of devices. Each device has a list of set of constraints that contribute to its overall ability to participate in demand-side load management. This breakout provides indication on the energy intensive processes and the respective energy percentages to the whole process. In order to examine industrial sectors by a two digit representation, the larger and more common manufacturing processes were extracted. These are considered the prevailing processes that drive the electrical energy consumption in these sectors and will be referred to as dominating processes. With the load curve classifications and energy estimations for each process step in hand, the development of load curves for each individual SIC consisted of breaking the overall load curves into portions based on the energy determined to be represented by the major process steps in the two digit sector code. As an example, the flat glass manufacturing industry which is housed within the industrial sector SIC 32 and has been provided the standard electrical breakdown shown in Table 2.1. This results in the PU load curve shown in Figure 2.7.

Table 2.1 Electric Loads Breakdown within a Given Manufacturing Sector

\begin{tabular}{|c|c|c|c|}
\hline $\mathrm{SIC}$ & Description & Dominating Process & $\begin{array}{l}\text { \%Electricity } \\
\text { Consumption* }\end{array}$ \\
\hline 32 & $\begin{array}{l}\text { Stone, Clay, Glass, and Concrete } \\
\text { Products }\end{array}$ & $\begin{array}{l}\text { Process1: Electric } \\
\text { Furnace }\end{array}$ & $17 \%$ \\
\hline 32 & $\begin{array}{l}\text { Stone, Clay, Glass, and Concrete } \\
\text { Products }\end{array}$ & Process2: Crushing & $36 \%$ \\
\hline
\end{tabular}

*[Brown, H.] 


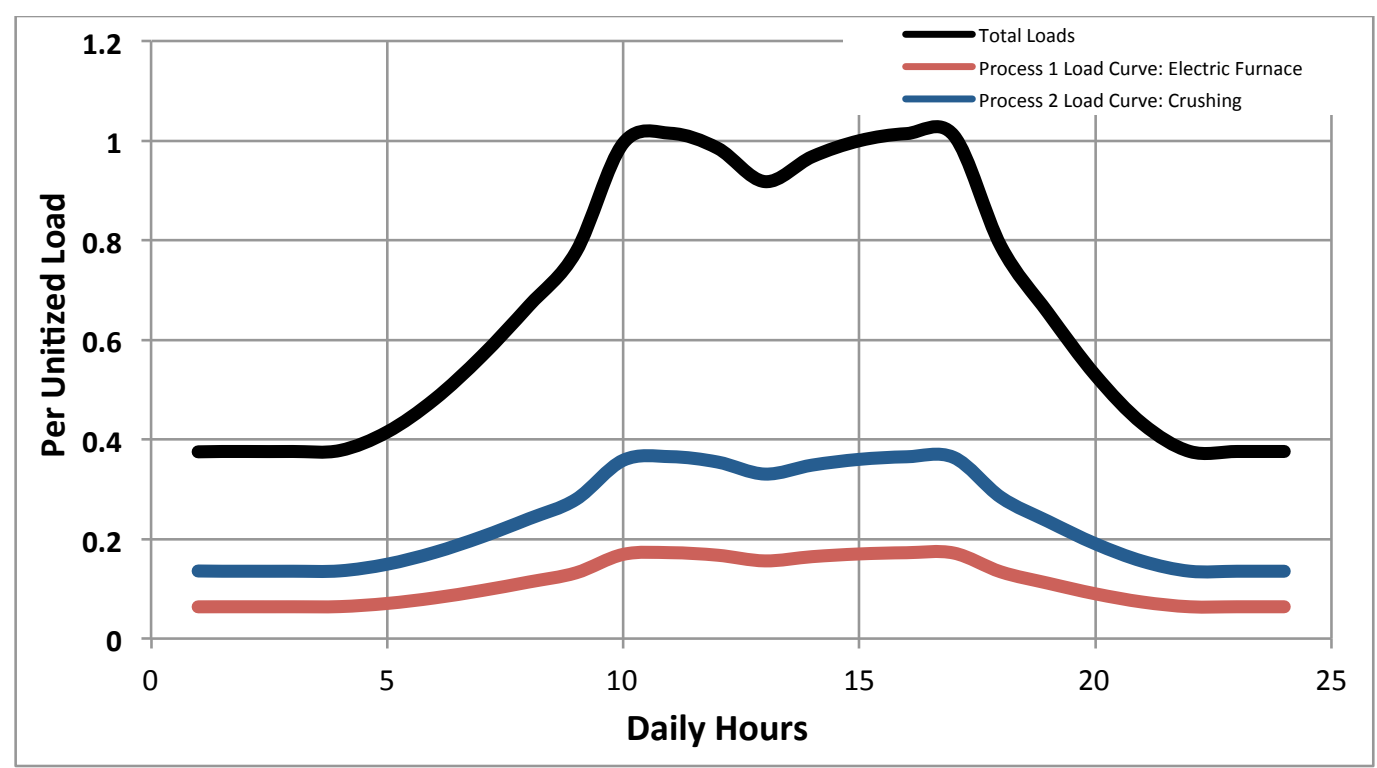

Figure 2.7 Daily Load Curve for Dominating Processes for SIC 32

In developing these load curves, several assumptions were made:

- Environmental conditions such as weather would not play a significant role. Although this is true for some industries where these industries may have HVAC loads that will change with weather conditions. However, the focus was mainly on manufacturing process loads (MPLs) more than HVAC loads since MPLs represent the most significant electrical energy consumers.

- Continuous operation. Processes may not be down for maintenance and the same load curve is applied throughout the year. Many industries from the IAC database have operating hours in the range of 8000 to 8760 , hence are operating most of the year.

- Process steps per SIC are standardized to develop a representation by industry. Each plant will have different operational scheme that may impact electrical energy consumption profile, but in this study, this level of detail cannot be achieved.

\subsection{Selection of Top Industrial Subsectors for DR Analysis}

The industrial sector is highly heterogeneous, with manufacturing processes represented by over 300,000 Manufacturing Plants across over 400 Industrial Sub-Sectors within the four digit Standard Industrial Classification (SIC) system. In order to prioritize the top industries for DR, we examined the total annual electricity consumption and average power demand per establishment as well as relied upon field experience. The prioritization led to 30 industrial subsectors codes represented in U.S. portions of the WI region.

To identify the top 30 industrial subsectors, a set of criteria were established to filter the available census data. The criteria were applied in a cascading and parallel fashion. In the cascade filter, each criterion was applied to the SIC industries. An industry was given a score between 0 and 10 for each criterion based on where the industry's figures ranked with respect to the criterion's thresholds. These scores were then weighted, summed and ranked across all other industries. The Top 10 for each criterion was captured and then 
compared to the cascade filter results. Industries that did not appear in the cascade filter were considered for inclusion into the top 30 list.

Table 2.2 Criterion Decision Matrix Weighting and Rankings for selecting top 30+ industrial subsectors [Enbala]

\begin{tabular}{|c|c|c|c|}
\hline CRITERIA & $\begin{array}{l}\text { WEIGHT } \\
(\%)\end{array}$ & RANKING & COMMENTS \\
\hline Electricity Consumption (GWh) & $40 \%$ & $1[500] \& 10[57400]$ & $\begin{array}{l}\text { Reported consumption for the } \\
\text { SIC group }\end{array}$ \\
\hline $\begin{array}{l}\text { Per Establishment Average } \\
\text { Power Demand (kW) }\end{array}$ & $35 \%$ & $1[500] \& 10[61500]$ & $\begin{array}{l}\text { Calculated per Establishment } \\
\text { Average Demand for the SIC } \\
\text { group }\end{array}$ \\
\hline $\begin{array}{l}\text { Establishments With Computer } \\
\text { Control of Process or Major } \\
\text { Energy Using Equipment }\end{array}$ & $15 \%$ & $1[<10 \%] \& 10[100 \%]$ & $\begin{array}{l}\text { \%of establishments in the SIC } \\
\text { group with Computer Control }\end{array}$ \\
\hline $\begin{array}{l}\text { Establishments With Adjustable } \\
\text { Speed Motors }\end{array}$ & $5 \%$ & $1[<10 \%] \& 10[100 \%]$ & $\begin{array}{l}\% \text { of establishments in the SIC } \\
\text { group with Adjustable Speed } \\
\text { Motors }\end{array}$ \\
\hline $\begin{array}{l}\text { Establishments With Participation } \\
\text { in Energy Management Activities }\end{array}$ & $5 \%$ & $1[<10 \%] \& 1[100 \%]$ & $\begin{array}{l}\% \text { of establishments in the SIC } \\
\text { group with Participating in } \\
\text { Energy Management Activities }\end{array}$ \\
\hline
\end{tabular}

In the following, we will explain each of these criteria in greater details.

\section{Criteria (1) Electricity Consumption}

Electrical consumption is defined by the net usage by a given industry and was used to identify large electricity consumers. Greater than $500 \mathrm{GWh}$ was the identified minimum threshold.

\section{Criteria (2) Per Establishment Average Power Demand}

Average power demand of more than $500 \mathrm{~kW}$ was used to determine that there is sufficient operating load for response to demand-side load participation. This has an impact on the economics to implement the facility for participation such that a sufficient response is attained. This also gives an indication that there are sizeable processes and devices that have flexible or interruptible loads.

\section{Criteria (3) Establishments with Computer Control of Process or Major Energy Users} Many demand-side energy management services that involve load participation require an automated response due to the speed the service needs to be called upon.

\section{Criteria (4) Establishments with Adjustable Speed Motors}

Loads that have the ability to be adjusted in an analog fashion can be integrated without shutting down processes, but have often been installed due to the flexible nature of the process. This adds another level of flexibility to demand-side load participation that binary loads cannot offer, however does not exclude binary devices from participation.

\section{Criteria (5) Establishments with Participation in Energy Management Activities}

Facilities that currently participate in energy management initiatives were determined to be actively participating in energy management activities and therefore deemed to be ideal candidates for other demand-side load energy management services. 


\subsection{Flexibility Factors}

To obtain an amount of participating load in each hour from the load profiles, a "flexibility" value is used for each hour, representing the fraction of load that is willing and able to participate in demand response at that hour. The true magnitude of participating load in 2020 can be estimated but is impossible to precisely predict. As more information becomes available, the assumed flexibility can be updated. The first assumptions that must be made are which loads can participate in which products. The assumed ability of each resource to contribute to these products is shown in Table 2.3.

Table 2.3 Participation of resources in different DR products

\begin{tabular}{|c|c|c|c|}
\hline SIC & Resource & Load Type & DR Product \\
\hline 20 & Packaging & Mechanical I & Capacity and Energy \\
\hline 20 & Chiller & Mechanical II & $\begin{array}{l}\text { Contingency and Flexibility Reserve } \\
\text { Regulation } \\
\text { Capacity and Energy }\end{array}$ \\
\hline 22 & Wrapping & Mechanical I & Capacity and Energy \\
\hline 22 & Weaving & Mechanical I & Capacity and Energy \\
\hline 24 & Sawing & Mechanical I & Capacity and Energy \\
\hline 24 & Planning & Mechanical I & Capacity and Energy \\
\hline 26 & Chipper & Mechanical I & Capacity and Energy \\
\hline 26 & Dewatering Press & Mechanical II & $\begin{array}{l}\text { Contingency and Flexibility Reserve } \\
\text { Regulation } \\
\text { Capacity and Energy }\end{array}$ \\
\hline 28 & Electrolysis & Thermal & $\begin{array}{l}\text { Contingency and Flexibility Reserve } \\
\text { Regulation } \\
\text { Capacity and Energy }\end{array}$ \\
\hline 28 & Compressor & Mechanical II & $\begin{array}{l}\text { Contingency and Flexibility Reserve } \\
\text { Regulation } \\
\text { Capacity and Energy }\end{array}$ \\
\hline 28 & Grinding & Mechanical I & Capacity and Energy \\
\hline 29 & Catalytic Cracking & Thermal & $\begin{array}{l}\text { Contingency and Flexibility Reserve } \\
\text { Regulation } \\
\text { Capacity and Energy }\end{array}$ \\
\hline 30 & Mixing & Mechanical II & $\begin{array}{l}\text { Contingency and Flexibility Reserve } \\
\text { Regulation } \\
\text { Capacity and Energy }\end{array}$ \\
\hline 30 & Mill & Mechanical I & Capacity and Energy \\
\hline 32 & Electric Furnace & Thermal & $\begin{array}{l}\text { Contingency and Flexibility Reserve } \\
\text { Regulation } \\
\text { Capacity and Energy }\end{array}$ \\
\hline 32 & Crushing & Mechanical I & Capacity and Energy \\
\hline 33 & Electrolysis & Thermal & $\begin{array}{l}\text { Contingency and Flexibility Reserve } \\
\text { Regulation } \\
\text { Capacity and Energy }\end{array}$ \\
\hline 33 & $\begin{array}{l}\text { Crushing and } \\
\text { Classifying }\end{array}$ & Mechanical I & Capacity and Energy \\
\hline 37 & Metal Cutting & Mechanical I & Capacity and Energy \\
\hline 37 & Final Assembly & Mechanical II & $\begin{array}{l}\text { Contingency and Flexibility Reserve } \\
\text { Regulation } \\
\text { Capacity and Energy }\end{array}$ \\
\hline
\end{tabular}




\subsubsection{Industrial Load Types}

The list of the resources in Table 2.3 captures the most likely candidate manufacturing processes that can participate in DR. This permits a deep dive approach to examine details of particular industrial manufacturing processes. As such, we have categorize these resources into three basic load types; Mechanical I, Mechanical II, and Thermal. Each of these load types may impact the type of DR product that can be delivered. In the following, we will explain each load type in more details.

Load Type Mechanical I refers to that manufacturing process equipment that exerts abruptly changing mechanical force or electric charge on a raw material during defined cycle time. Examples are found in mechanical and hydraulic presses, forging presses, grinders, chippers, etc. These type of loads may not be able to modulate, but can be turned ON/OFF for extended period of time if needed. For this reason, these types of devices are most suitable to provide Capacity and Energy DR products.

Load Type Mechanical II refers to that manufacturing process equipment that exerts consistent force on a moving media such as fluids, conveyors, etc. Examples are found in machine drives such as pumps, fans, blowers, air compressors, etc. These loads can modulate given that they are equipped with suitable control devices such as variable frequency drives (VFD) or set back thermostats. However, sufficient precautions need to be taken as too frequent starts can cause overheating and may shorten life duration of insulating parts in the electric motor. For this reason, these types of devices are most suitable to provide all five products of DR.

Load Type Thermal refers to the manufacturing process equipment that changes the phase, composition or chemical characteristics of a raw material and is continuously running unless interrupted by maintenance or production schedule change. Examples are found in smelters, continuously operating metal heat treatment furnaces, electrolytic cells, induction melting furnaces, etc. If these loads are interrupted, they may or may not restart the cycle from the interruption point. This will depend on the duration of the interruption and on the type of process involved. Heat treatments, for example, are not likely to produce metals with the required characteristics if they do not proceed according to the scheduled sequence of heating and cooling. For this reason, these types of devices are most suitable to provide all five products of DR.

\subsubsection{Derivation of the Industrial Demand Response Flexibility-Factor (IDRFF)}

The industrial DR flexibility is assimilated from the product of the following four factors:

- Factor 1: Acceptability based on Type of Industrial Sector

- Factor 2: Controllability based on Type of Load

- Factor 3: Sheddability Process based on Type of Process

- Factor 4: Sheddability Device based on Type of Device

Factor 1 is the Acceptability multiplier which represents the overall acceptability of a given industrial sector to be engaged in DR projects. This multiplier is based on statistical analysis of data from EIA-MECS Energy Management Activities and Energy-Savings 
Technologies. Numbers reflect the likelihood for a given sector to embrace the concept of LSM.

Factor 2 is the Controllability multiplier for a given process and device. It determines the extent that a given load or process can be controlled. This is a Binary Factor, i.e., zero (0) or one (1). We assign zero (0) for Mechanical I type of loads where the load has no ability to be controlled or modulated to meet a specific demand response product. We assign one

(1) for Mechanical II and Thermal type of loads where the load can be controlled or be ramped up and down, i.e., can be switched ON or OFF.

Factor 3 is the Sheddability Process multiplier for a given manufacturing process. It determines the extent that a given process can be shed by a typical demand response strategy. This factor ranges from zero (0) to one (1) depending on the nature of the process whether it is isolated (often associated with Mechanical II), in sequence without storage (often seen with Mechanical I), or in sequence with some storage capability (as is often the case with Thermal and Mechanical II type of loads). If the process is completely isolated, meaning that downstream processes are not dependent on this specific process, we assign a value of one. If there is storage ahead of the process, we assign a multiplier that is less than one depending on the nature of this storage (mechanical or thermal). If the process is in sequence and without any storage, we assign a factor that is equal to zero (0) (if the process is critical) and less than one if the process is not as critical to the flow of the industrial process. A value ranging between zero (0) and one (1) is provided for processes in sequence with storage depending on the quantity of storage.

Factor 4 is the Sheddability Device multiplier that determines if there is any impact on device reliability and controllability. In terms of reliability, frequent modulation or shutting down/start up functions due to DR activities are considered. It determines the device flexibility for its specific function within the Process Step. This number is based on NEMA MG 1-2006, 12.44. Multiplier one is used if there is a minimal impact on the device due to frequent shutdown/start up. Multiplier zero to one is used if there are some impacts. Multiplier zero indicates that he device can't be engaged in any DR activities. As a general guideline: for devices that are $100 \mathrm{hp}$ or less, a multiplier of (0.8-1) can be used whereas for devices $>100 \mathrm{hp}$, a multiplier of 0.2-0.8 can be used. In terms of controllability, the existence of a speed control device (VFD) or a thermostat offer extensive control of a given device allowing it to respond to a DR strategy upon request.

Based on the above analysis, we developed the following formulae for the Industrial Demand Response Flexibility-Factor (IDRFF) as follows:

$$
\begin{aligned}
\operatorname{IDRFF}(\mathrm{SIC}, \text { Load, } & \text { Process, Device, DR Product) } \\
& =\min (\text { Sector Acceptability, Load Controllability) } \\
& \times \min \text { (Sheddability Process, Sheddability Device) }
\end{aligned}
$$

The minimum of the acceptability and controllability of the process type or device type is used as a multiplier against minimum of the Sheddability of the process or device to obtain the final IDRFF. 
Using the above analysis, we are now able to derive the industrial demand response flexibility for the top selected industry sectors as represented by tables in Appendix C:

- Tables C.1, C.2, and C.3: Dominating Process \& Load Characterization for the top selected industrial sectors (20-37)

- Table C.4: Acceptability Percentages

- Table C.5: Controllability Percentages

- Table C.6: Sheddability of the Manufacturing Process

- Table C.7: Sheddability of the Device within the Manufacturing Process

\subsection{Assumptions}

The following assumptions provide a solid ground for the developed flexibility and other characteristic information needed to be captured in the results:

1. The ramp rate is $100 \%$ of the available product for all loads and all SICs

2. All values represent flexibility or the percentage of loads in a given process step that are available for a given DR Product.

3. Multiple process lines are available and provide opportunities for process storage.

4. DR Product assigned to a given process step should have (as much as it is feasible) a minimal impact on production quality and yield - Values assigned to DR product per process step is taking this into consideration.

5. In the case of multiple process steps: (a) If you choose to apply energy, or capacity to a given process, other downstream processes must be used as well; meaning, they should follow same scheme of DR as they are all interdependent and changes in this given process load will impact downstream processes and these DR products must be applied as well.

6. In case of single process steps, choose between contingency or flex, but not both, choose between energy or capacity, but not both.

7. The development of information regarding how often and how long are based on: the nature of the production process steps within a given industrial sector SIC (single vs. multiple) - (critical vs. non critical).

Based on the assumptions, Table 2.4 shows the DR product constraints within each twodigit industrial sector and Table 2.5 shows DR resource ramping times for slow and fast responses. 
Table 2.4 DR Product constraints

\begin{tabular}{|c|c|c|c|c|c|c|}
\hline SIC Sector & Resource & $\begin{array}{l}\text { Minimum } \\
\text { Duration }\end{array}$ & Maximum Duration & Call Limits & Energy Payback & DR Product Type \\
\hline 20 & Packaging & $0.5 \mathrm{hr}$ & $1 \mathrm{hr}$ & $\begin{array}{l}1-2 \text { times per day } \\
\text { with } 4-8 \text { hour } \\
\text { notification }\end{array}$ & $100 \%$ within $24 \mathrm{hrs}$ & Capacity and Energy \\
\hline \multirow[t]{3}{*}{20} & \multirow[t]{3}{*}{ Chiller } & \multirow[t]{3}{*}{$0.5 \mathrm{hr}$} & \multirow[t]{3}{*}{$1 \mathrm{hr}$} & $\leq$ Once per day & $100 \%$ within $24 \mathrm{hrs}$ & Contingency and FLEX \\
\hline & & & & $\begin{array}{l}\text { Continuous within } \\
\text { specified bid } \\
\text { period }\end{array}$ & $100 \%$ within $24 \mathrm{hrs}$ & Regulation \\
\hline & & & & $\begin{array}{l}\text { 1-2 times per day } \\
\text { with } 4-8 \text { hour } \\
\text { notification }\end{array}$ & $100 \%$ within $24 \mathrm{hrs}$ & Capacity and Energy \\
\hline 22 & Wrapping & $1 \mathrm{hr}$ & $1 \mathrm{hr}$ & $\begin{array}{l}\text { 1-2 times per day } \\
\text { with } 4-8 \text { hour } \\
\text { notification }\end{array}$ & $100 \%$ within $24 \mathrm{hrs}$ & Capacity and Energy \\
\hline 22 & Weaving & $1 \mathrm{hr}$ & $1 \mathrm{hr}$ & $\begin{array}{l}1-2 \text { times per day } \\
\text { with } 4-8 \text { hour } \\
\text { notification }\end{array}$ & $100 \%$ within 24 hrs & Capacity and Energy \\
\hline 24 & Sawing & $0.5 \mathrm{hr}$ & $1 \mathrm{hr}$ & $\begin{array}{l}1-2 \text { times per day } \\
\text { with } 4-8 \text { hour } \\
\text { notification }\end{array}$ & $100 \%$ within $24 \mathrm{hrs}$ & Capacity and Energy \\
\hline 24 & Planning & $0.5 \mathrm{hr}$ & $1 \mathrm{hr}$ & $\begin{array}{l}\text { 1-2 times per day } \\
\text { with } 4-8 \text { hour } \\
\text { notification }\end{array}$ & $100 \%$ within $24 \mathrm{hrs}$ & Capacity and Energy \\
\hline 26 & Chipper & $1 \mathrm{hr}$ & $4 \mathrm{hrs}$ & $\begin{array}{l}\text { 1-2 times per day } \\
\text { with } 4-8 \text { hour } \\
\text { notification }\end{array}$ & $100 \%$ within $24 \mathrm{hrs}$ & Capacity and Energy \\
\hline \multirow[t]{3}{*}{26} & \multirow{3}{*}{$\begin{array}{l}\text { Dewatering } \\
\text { Press }\end{array}$} & \multirow[t]{3}{*}{$0.5 \mathrm{hr}$} & \multirow[t]{3}{*}{$1 \mathrm{hr}$} & $\leq$ Once per day & $100 \%$ within 24 hrs & Contingency and FLEX \\
\hline & & & & $\begin{array}{l}\text { Continuous within } \\
\text { specified bid } \\
\text { period }\end{array}$ & $100 \%$ within $24 \mathrm{hrs}$ & Regulation \\
\hline & & & & $\begin{array}{l}\text { 1-2 times per day } \\
\text { with } 4-8 \text { hour } \\
\text { notification }\end{array}$ & $100 \%$ within $24 \mathrm{hrs}$ & Capacity and Energy \\
\hline \multirow[t]{3}{*}{28} & \multirow[t]{3}{*}{ Electrolysis } & \multirow[t]{3}{*}{$4 \mathrm{hrs}$} & \multirow[t]{3}{*}{$8 \mathrm{hrs}$} & $\leq$ Once per day & $100 \%$ within $24 \mathrm{hrs}$ & Contingency and FLEX \\
\hline & & & & $\begin{array}{l}\text { Continuous within } \\
\text { specified bid } \\
\text { period }\end{array}$ & $100 \%$ within $24 \mathrm{hrs}$ & Regulation \\
\hline & & & & $\begin{array}{l}\text { 1-2 times per day } \\
\text { with } 4-8 \text { hour } \\
\text { notification }\end{array}$ & $100 \%$ within $24 \mathrm{hrs}$ & Capacity and Energy \\
\hline \multirow[t]{3}{*}{28} & \multirow[t]{3}{*}{ Compressor } & \multirow[t]{3}{*}{$1 \mathrm{hr}$} & \multirow[t]{3}{*}{$3 \mathrm{hrs}$} & $\leq$ Once per day & $100 \%$ within $24 \mathrm{hrs}$ & Contingency and FLEX \\
\hline & & & & $\begin{array}{l}\text { Continuous within } \\
\text { specified bid } \\
\text { period }\end{array}$ & $100 \%$ within 24 hrs & Regulation \\
\hline & & & & $\begin{array}{l}1-2 \text { times per day } \\
\text { with } 4-8 \text { hour } \\
\text { notification }\end{array}$ & $100 \%$ within $24 \mathrm{hrs}$ & Capacity and Energy \\
\hline 28 & Grinding & $1 \mathrm{hr}$ & $4 \mathrm{hrs}$ & $\begin{array}{l}\text { 1-2 times per day } \\
\text { with } 4-8 \text { hour } \\
\text { notification }\end{array}$ & $100 \%$ within $24 \mathrm{hrs}$ & Capacity and Energy \\
\hline \multirow[t]{3}{*}{29} & \multirow{3}{*}{$\begin{array}{l}\text { Catalytic } \\
\text { Cracking }\end{array}$} & \multirow[t]{3}{*}{$0.5 \mathrm{hr}$} & \multirow[t]{3}{*}{$1 \mathrm{hr}$} & $\leq$ Once per day & $100 \%$ within $24 \mathrm{hrs}$ & Contingency and FLEX \\
\hline & & & & $\begin{array}{l}\text { Continuous within } \\
\text { specified bid } \\
\text { period }\end{array}$ & $100 \%$ within $24 \mathrm{hrs}$ & Regulation \\
\hline & & & & $\begin{array}{l}1-2 \text { times per day } \\
\text { with } 4-8 \text { hour } \\
\text { notification }\end{array}$ & $100 \%$ within $24 \mathrm{hrs}$ & Capacity and Energy \\
\hline \multirow[t]{3}{*}{30} & \multirow[t]{3}{*}{ Mixing } & \multirow[t]{3}{*}{$0.5 \mathrm{hr}$} & \multirow[t]{3}{*}{$1 \mathrm{hr}$} & $\leq$ Once per day & $100 \%$ within $24 \mathrm{hrs}$ & Contingency and FLEX \\
\hline & & & & $\begin{array}{l}\text { Continuous within } \\
\text { specified bid } \\
\text { period }\end{array}$ & $100 \%$ within $24 \mathrm{hrs}$ & Regulation \\
\hline & & & & $\begin{array}{l}\text { 1-2 times per day } \\
\text { with } 4-8 \text { hour } \\
\text { notification }\end{array}$ & $100 \%$ within $24 \mathrm{hrs}$ & Capacity and Energy \\
\hline 30 & Mill & $0.5 \mathrm{hr}$ & $1 \mathrm{hr}$ & $\begin{array}{l}\text { 1-2 times per day } \\
\text { with } 4-8 \text { hour } \\
\text { notification }\end{array}$ & $100 \%$ within 24 hrs & Capacity and Energy \\
\hline \multirow[t]{2}{*}{32} & \multirow{2}{*}{$\begin{array}{l}\text { Electric } \\
\text { Furnace }\end{array}$} & \multirow[t]{2}{*}{$0.5 \mathrm{hr}$} & \multirow[t]{2}{*}{$1 \mathrm{hr}$} & $\leq$ Once per day & $100 \%$ within $24 \mathrm{hrs}$ & Contingency and FLEX \\
\hline & & & & $\begin{array}{l}\text { Continuous within } \\
\text { specified bid }\end{array}$ & $100 \%$ within 24 hrs & Regulation \\
\hline
\end{tabular}




\begin{tabular}{|c|c|c|c|c|c|c|}
\hline & & & & \multicolumn{3}{|l|}{ period } \\
\hline & & & & $\begin{array}{l}1-2 \text { times per day } \\
\text { with } 4-8 \text { hour } \\
\text { notification }\end{array}$ & $100 \%$ within $24 \mathrm{hrs}$ & Capacity and Energy \\
\hline 32 & Crushing & $1 \mathrm{hr}$ & $4 \mathrm{hrs}$ & $\begin{array}{l}\text { 1-2 times per day } \\
\text { with } 4-8 \text { hour } \\
\text { notification }\end{array}$ & $100 \%$ within $24 \mathrm{hrs}$ & Capacity and Energy \\
\hline \multirow[t]{3}{*}{33} & \multirow[t]{3}{*}{ Electrolysis } & \multirow[t]{3}{*}{$4 \mathrm{hrs}$} & \multirow[t]{3}{*}{$8 \mathrm{hrs}$} & $\leq$ Once per day & $100 \%$ within $24 \mathrm{hrs}$ & Contingency and FLEX \\
\hline & & & & $\begin{array}{l}\text { Continuous within } \\
\text { specified bid } \\
\text { period }\end{array}$ & $100 \%$ within $24 \mathrm{hrs}$ & Regulation \\
\hline & & & & $\begin{array}{l}1-2 \text { times per day } \\
\text { with } 4-8 \text { hour } \\
\text { notification }\end{array}$ & $100 \%$ within $24 \mathrm{hrs}$ & Capacity and Energy \\
\hline 33 & $\begin{array}{l}\text { Crushing } \\
\text { and } \\
\text { Classifying }\end{array}$ & $1 \mathrm{hr}$ & $4 \mathrm{hrs}$ & $\begin{array}{l}\text { 1-2 times per day } \\
\text { with } 4-8 \text { hour } \\
\text { notification }\end{array}$ & $100 \%$ within $24 \mathrm{hrs}$ & Capacity and Energy \\
\hline 37 & $\begin{array}{l}\text { Metal } \\
\text { Cutting }\end{array}$ & $1 \mathrm{hr}$ & $4 \mathrm{hrs}$ & $\begin{array}{l}1-2 \text { times per day } \\
\text { with } 4-8 \text { hour } \\
\text { notification }\end{array}$ & $100 \%$ within $24 \mathrm{hrs}$ & Capacity and Energy \\
\hline \multirow[t]{3}{*}{37} & \multirow{3}{*}{$\begin{array}{c}\text { Final } \\
\text { Assembly }\end{array}$} & \multirow[t]{3}{*}{$0.5 \mathrm{hr}$} & \multirow[t]{3}{*}{$1 \mathrm{hr}$} & $\leq$ Once per day & $100 \%$ within $24 \mathrm{hrs}$ & Contingency and FLEX \\
\hline & & & & $\begin{array}{l}\text { Continuous within } \\
\text { specified bid } \\
\text { period }\end{array}$ & $100 \%$ within $24 \mathrm{hrs}$ & Regulation \\
\hline & & & & $\begin{array}{l}\text { 1-2 times per day } \\
\text { with } 4-8 \text { hour } \\
\text { notification }\end{array}$ & $100 \%$ within $24 \mathrm{hrs}$ & Capacity and Energy \\
\hline
\end{tabular}

Table 2.5 Resource Ramping Times for Slow and Fast Responses

\begin{tabular}{|c|l|c|l|}
\hline $\begin{array}{c}\text { SIC } \\
\text { Sector }\end{array}$ & Resource & $\begin{array}{l}\text { Faster Response Ramp } \\
\text { Time }\end{array}$ & $\begin{array}{l}\text { Slower } \\
\text { Respons } \\
\text { e Ramp } \\
\text { Time }\end{array}$ \\
\hline $\mathbf{2 0}$ & Packaging & 5 Minutes & $\begin{array}{l}10 \\
\text { Minutes }\end{array}$ \\
\hline $\mathbf{2 0}$ & Chiller & 30 seconds & $\begin{array}{l}10 \\
\text { Minute }\end{array}$ \\
\hline $\mathbf{2 2}$ & Wrapping & 5 Minutes & $\begin{array}{l}10 \\
\text { Minutes }\end{array}$ \\
\hline $\mathbf{2 2}$ & Weaving & 5 Minutes & $\begin{array}{l}10 \\
\text { Minutes }\end{array}$ \\
\hline $\mathbf{2 4}$ & Sawing & 5 Minutes & $\begin{array}{l}10 \\
\text { Minutes }\end{array}$ \\
\hline $\mathbf{2 4}$ & Planning & 5 Minutes & $\begin{array}{l}10 \\
\text { Minutes }\end{array}$ \\
\hline $\mathbf{2 6}$ & Chipper & 5 Minutes & $\begin{array}{l}10 \\
\text { Minutes }\end{array}$ \\
\hline $\mathbf{2 8}$ & Grinding & 50 Minutes & $\begin{array}{l}10 \\
\text { Minutes }\end{array}$ \\
\hline $\mathbf{2 8}$ & $\begin{array}{l}\text { Electrolysi } \\
\text { s Press }\end{array}$ & 30 seconds & $\begin{array}{l}10 \\
\text { Minute }\end{array}$ \\
\hline
\end{tabular}

\begin{tabular}{|c|c|c|c|}
\hline $\begin{array}{l}\text { SIC } \\
\text { Sector }\end{array}$ & $\begin{array}{l}\text { Resourc } \\
\text { e }\end{array}$ & $\begin{array}{l}\text { Faster Response Ramp } \\
\text { Time }\end{array}$ & $\begin{array}{l}\text { Slower } \\
\text { Respons } \\
\text { e Ramp } \\
\text { Time }\end{array}$ \\
\hline 29 & $\begin{array}{l}\text { Catalytic } \\
\text { Cracking }\end{array}$ & 30 seconds & $\begin{array}{l}10 \\
\text { Minute }\end{array}$ \\
\hline 30 & Mixing & 30 seconds & $\begin{array}{l}10 \\
\text { Minute }\end{array}$ \\
\hline 30 & Mill & 5 Minutes & $\begin{array}{l}10 \\
\text { Minutes }\end{array}$ \\
\hline 32 & $\begin{array}{l}\text { Electric } \\
\text { Furnace }\end{array}$ & 30 seconds & $\begin{array}{l}10 \\
\text { Minute }\end{array}$ \\
\hline 32 & Crushing & 5 Minutes & $\begin{array}{l}10 \\
\text { Minutes }\end{array}$ \\
\hline 33 & $\begin{array}{l}\text { Electrolys } \\
\text { is }\end{array}$ & 30 seconds & $\begin{array}{l}10 \\
\text { Minute }\end{array}$ \\
\hline 33 & $\begin{array}{l}\text { Crushing } \\
\text { and } \\
\text { Classifyin } \\
\mathrm{g}\end{array}$ & 5 Minutes & $\begin{array}{l}10 \\
\text { Minutes }\end{array}$ \\
\hline 37 & $\begin{array}{l}\text { Metal } \\
\text { Cutting } \\
\end{array}$ & 5 Minutes & $\begin{array}{l}10 \\
\text { Minutes }\end{array}$ \\
\hline 37 & $\begin{array}{l}\text { Final } \\
\text { Assembly }\end{array}$ & 30 seconds & $\begin{array}{l}10 \\
\text { Minute }\end{array}$ \\
\hline
\end{tabular}




\section{Chapter 3 RESULTS}

\subsection{Industrial DR Profiles Aggregation in Western Interconnect (WI)}

Using the IGATE-E@ framework, we established databases of industrial electrical energy consumption, signature load curve by each type of industry, and identified flexibility factors by each industry type as represented by the two-digit SIC. The information was consolidated to develop the available demand response quantities for each plant within WI and was accumulated into a single value for evaluation (Bottom up Approach). The process flow is shown in Error! Reference source not found..

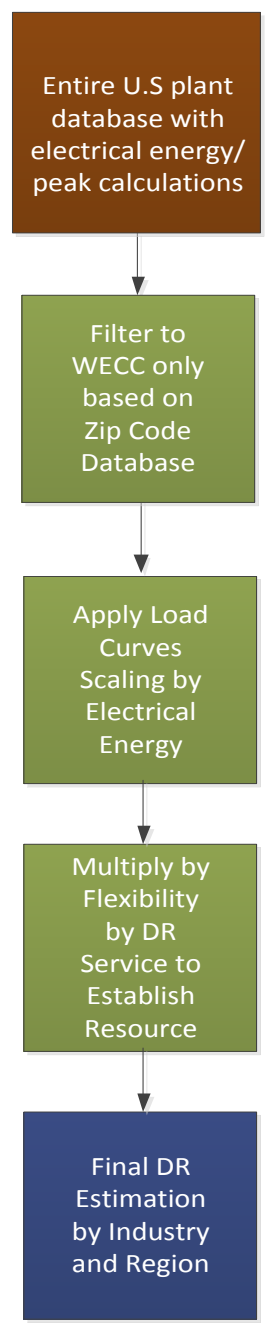

Figure 3.1 Process flow to establish final available DR quantities

The initial database of plants with electrical energy calculated is filtered to remove all plants that are not within WI regions, and to associate each set of plants with the corresponding balancing area in WI which is established by a list of zip codes. The load curves developed by the genetic algorithm are used and scaled based on the electrical plant calculated energy and type of industry for each process step. A flexibility figure is used to multiply 
these process curves to obtain the final demand response curve. Analysis regarding the findings can be found the following sections.

\subsection{Industrial Plants in WI Region}

A total of 59,941 manufacturing plants in WI region representing 20 industrial sectors (SIC 20-39) were analyzed to establish the potential industrial DR products in WI. The distributions of plants among the 20 industrial sectors are shown in Figure 3.2. The count by plant shows that SIC 35 (Computer Equipment and Industrial and Commercial Machinery) accounts for the highest number of manufacturing plants in the WI region, followed by SIC 27 (Printing, Publishing, and Allied Industries). Fabricated metal Products (SIC 34) and Food Products comes next.

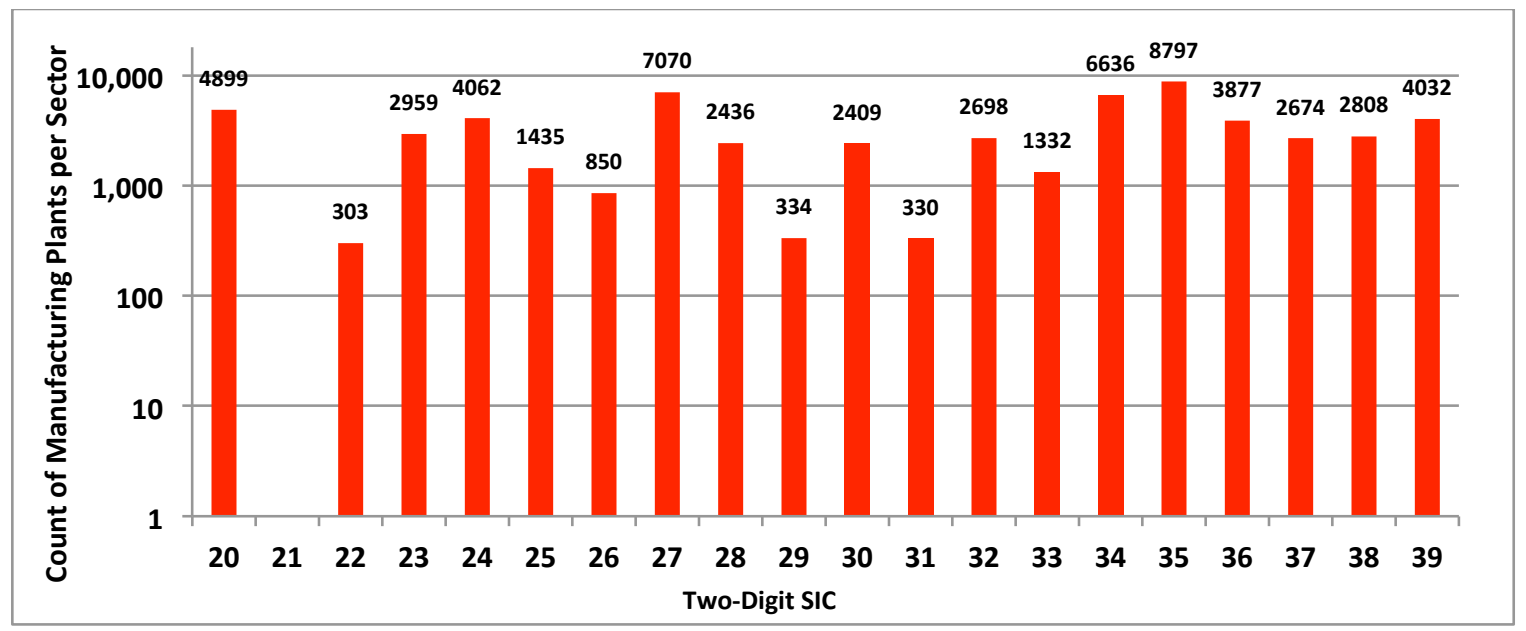

Figure 3.2 Count of Industries Selected in WI Zone by Two-Digit SIC*

*Sectors SICs (21, 34, 35, 36, 38, and 39) are not included in the study [Refer to Executive Summary]

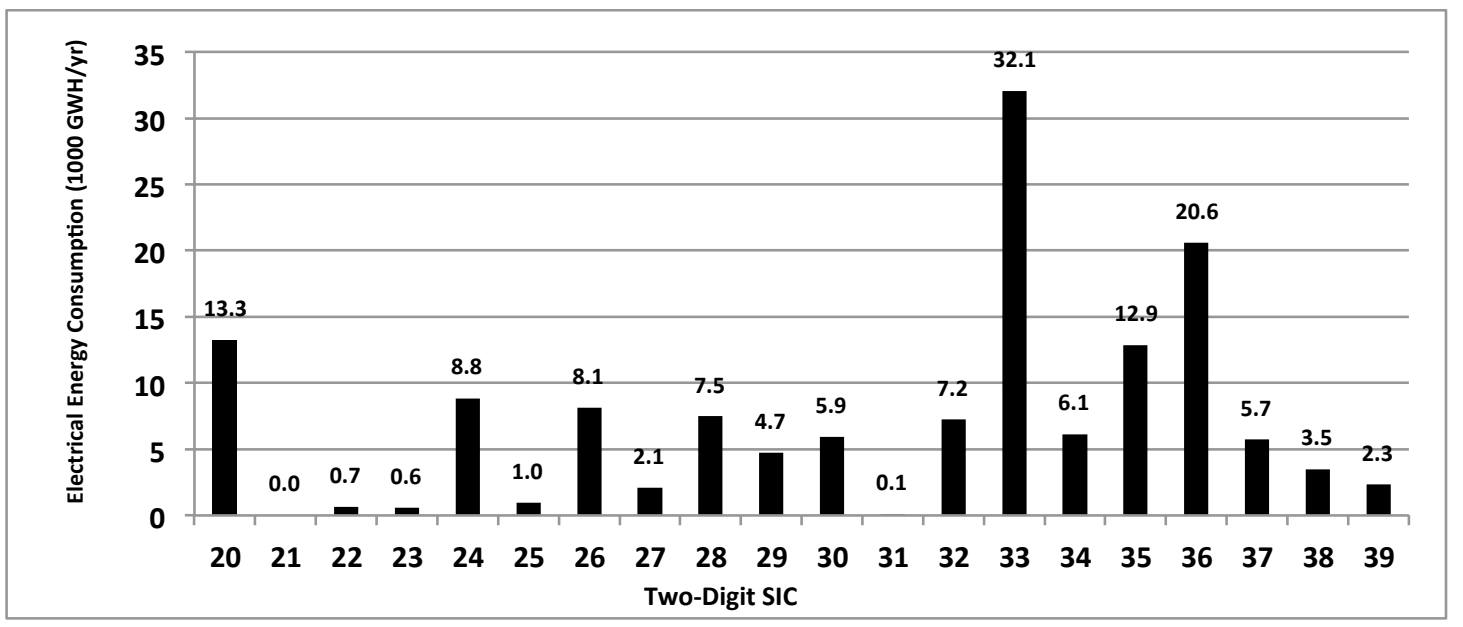

Figure 3.3 Estimated Electrical Energy Consumption of All Industries in WI Region by Two-Digit SIC*

*Sectors SICs (21, 34, 35, 36, 38, and 39) are not included in the study [Refer to Executive Summary] 
The total estimated industrial electrical energy consumption in WI region is 143,000 GWh/yr. Figure 3.3 shows the breakdown of the electrical energy consumption of all 59,941 manufacturing plants in WI region by industrial sector based on two-digit SIC. The electrical energy consumption figures were estimated using the IGATE-E@ framework described in details in Appendix A. The results show that SIC 33 (Primary Metal Sector) accounts for the highest electrical energy consumed in relation to the examined industries (approximately $22 \%$ of the electrical energy), followed by SIC 36 (Electronics and Other Electrical Equipment and Components) which account for $14 \%$ of the total electrical energy in WI region.

Figure 2.4 shows the total actual electrical energy consumption within each WI zone (WI Region) compared to the estimated total industrial electrical energy consumption in WI Zone using IGATE-E@ framework [Appendix A]. As can be seen in Figure 2.4, the total annual electrical energy consumption from industrial loads has been estimated to be 143 billion kWh. EIA actual data shows an annual energy consumption of 154 billion $\mathrm{kWh}$ for in industrial load (EIA 2013). EIA estimates that the industrial loads in the WI region represent only $\mathbf{2 3 . 5 \%}$ of the total electrical load (EIA 2013) with most of the remaining load allocated to commercial and residential sectors.

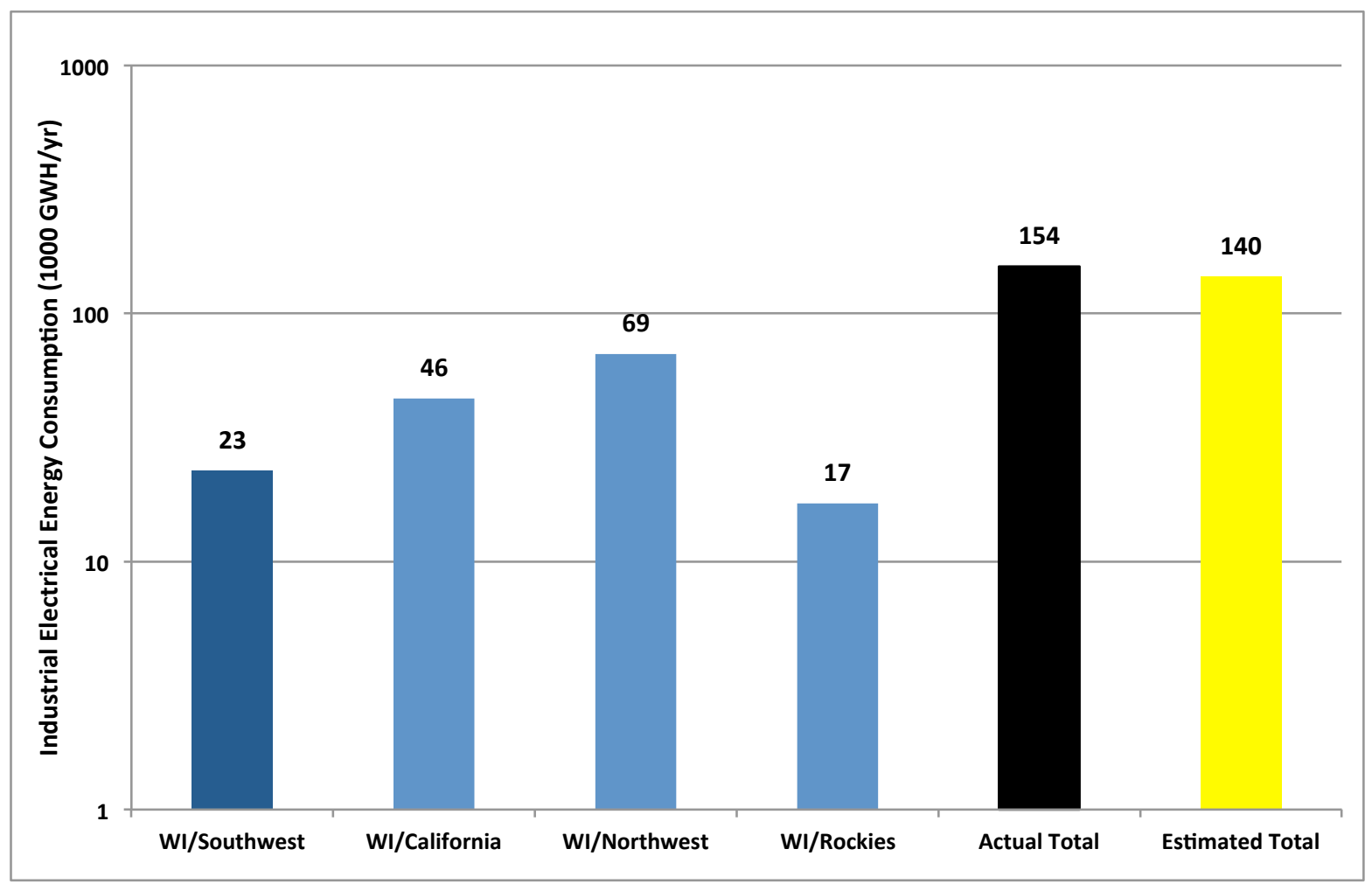

Figure 3.4 Actual (with breakdowns) vs. Estimated Total Industrial Electrical Energy Consumption in WI Zone

\subsubsection{BAA Summaries}

Based on the analysis, there is a wide range of industrial load availability for the five different demand response products among the thirty-six BAAs in WI region. Not only are 
there large differences in average relative DR product availability, there are also differences in the variability of this availability. These differences are due to differences in the relative magnitude of industrial end-uses in each BAA and assumed differences in the end-user population's willingness to shed load based on type of the type manufacturing process.

The analysis considers the amount of demand response availability for each type of demand response product. Two case scenarios are developed in the analysis; Scenario 1 represents the estimated availability based on most recent data from DOE EIA-MECS. Scenario 2 represents the estimated availability considering full acceptability by industry by 2020. Scenario 2 can be referred to as "Technical Potential". The range of DR product availability by BAA for Scenario 1 can be seen in Figure 3.5to 3.9 for Regulation, Flexibility, and Contingency, Energy, and Capacity. The range of DR product availability by BAA for Scenario 2 can be seen in Figure 3.510 to 3.14 for the same five DR products. 


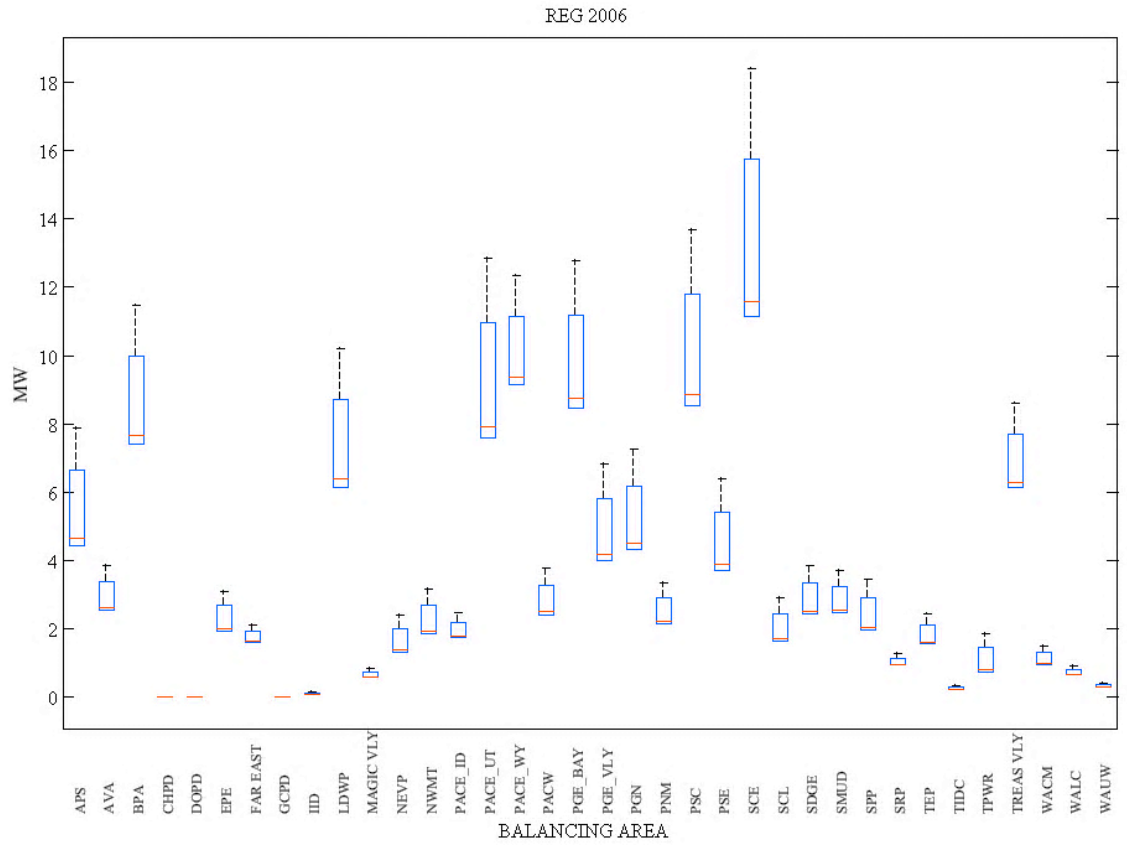

Figure 3.5 Regulation Availability by MW per BAA (Scenario 1)

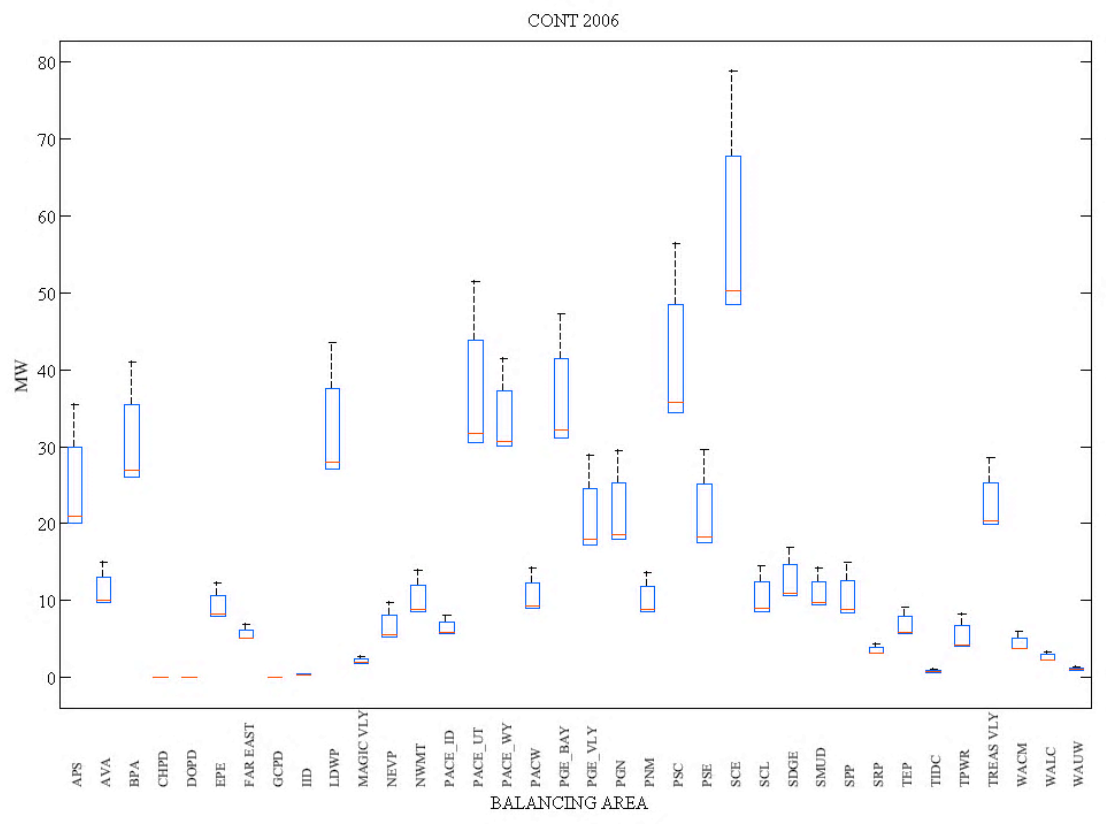

Figure 3.6 Contingency Availability by MW per BAA (Scenario 1) 


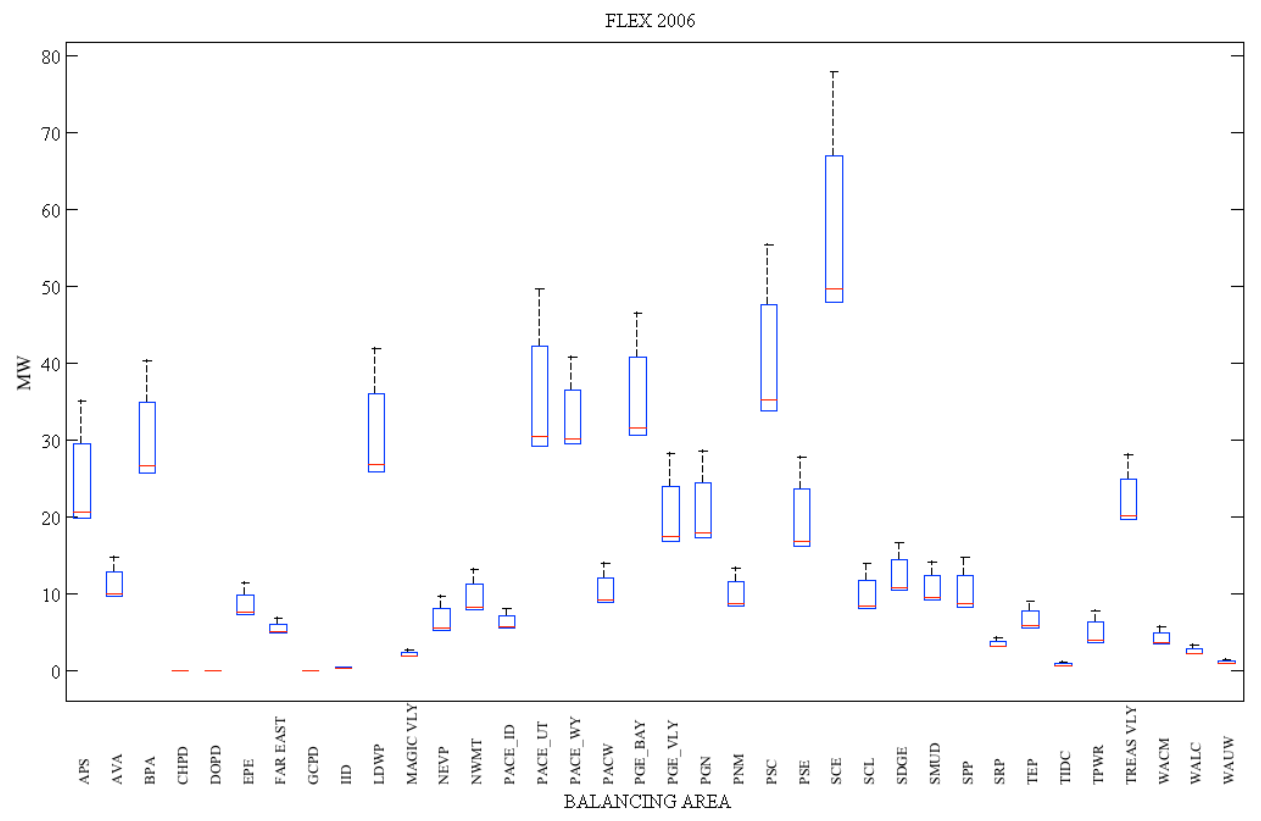

Figure 3.7 Flex Availability by MW per BAA (Scenario 1)

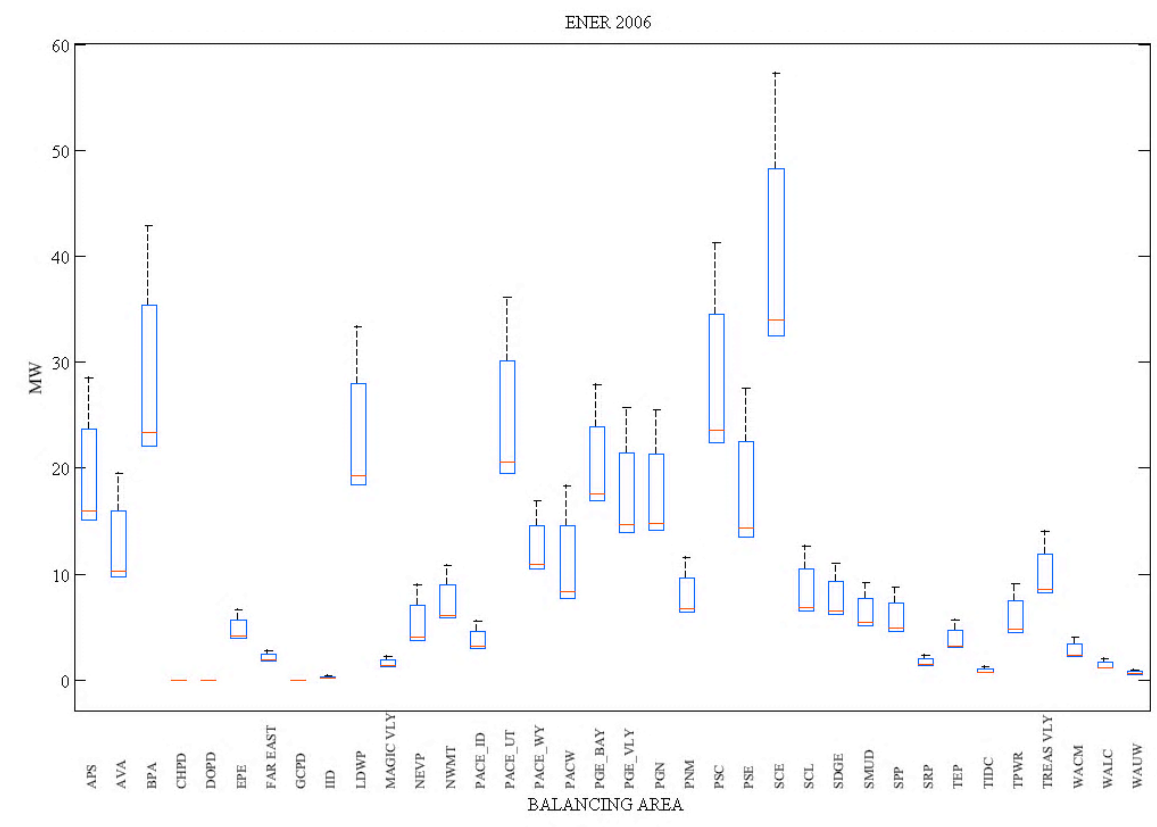

Figure 3.8 Energy Availability by MW per BAA (Scenario 1) 


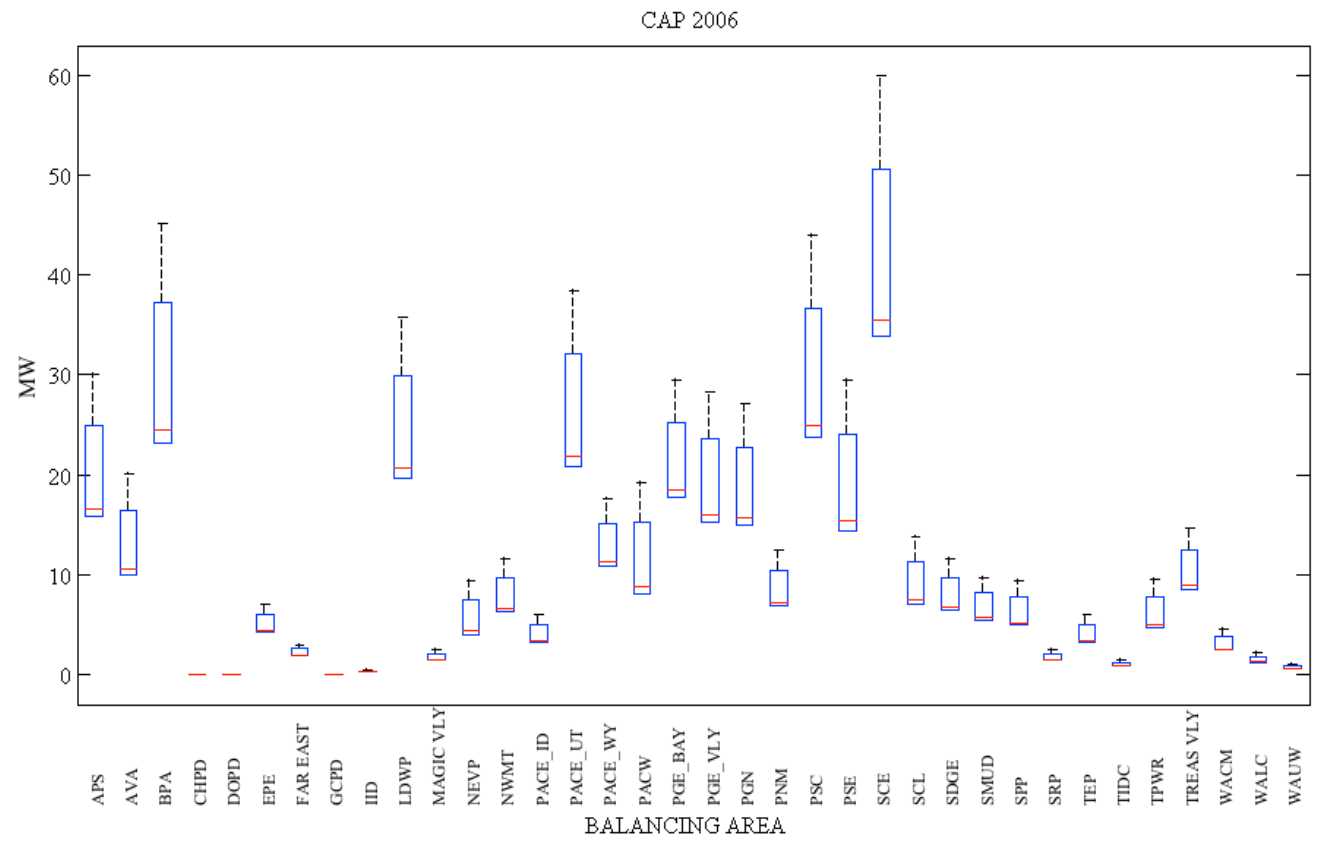

Figure 3.9 Capacity Availability by MW per BAA (Scenario 1)

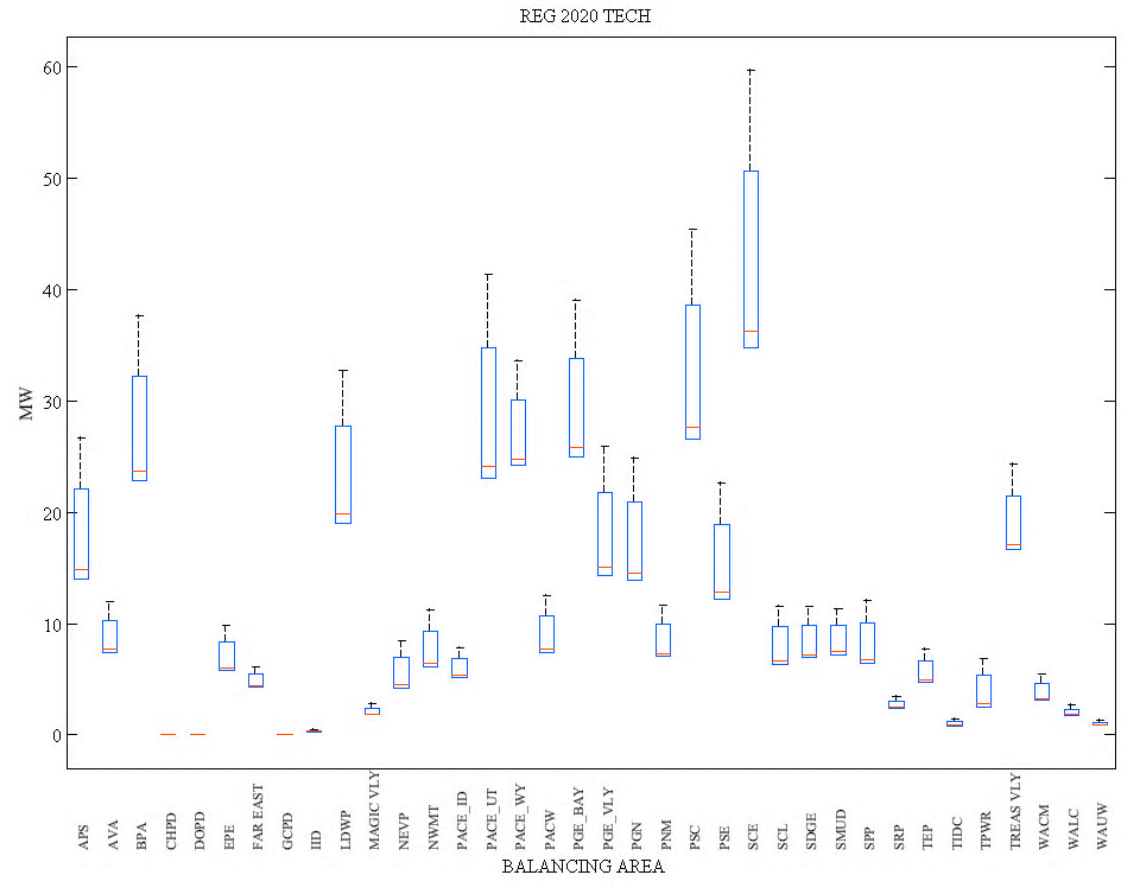

Figure 3.10 Regulation Availability by MW per BAA (Scenario 2) 


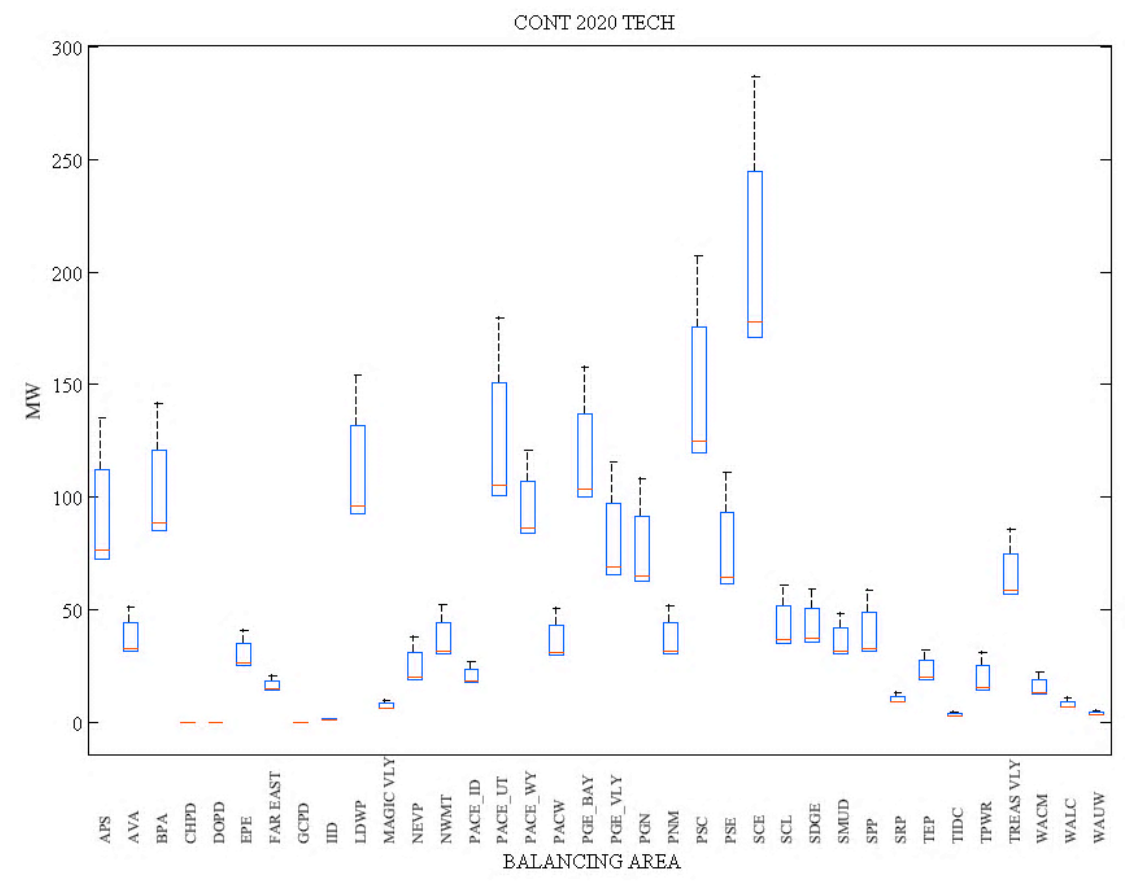

Figure 3.11 Contingency Availability by MW per BAA (Scenario 2)

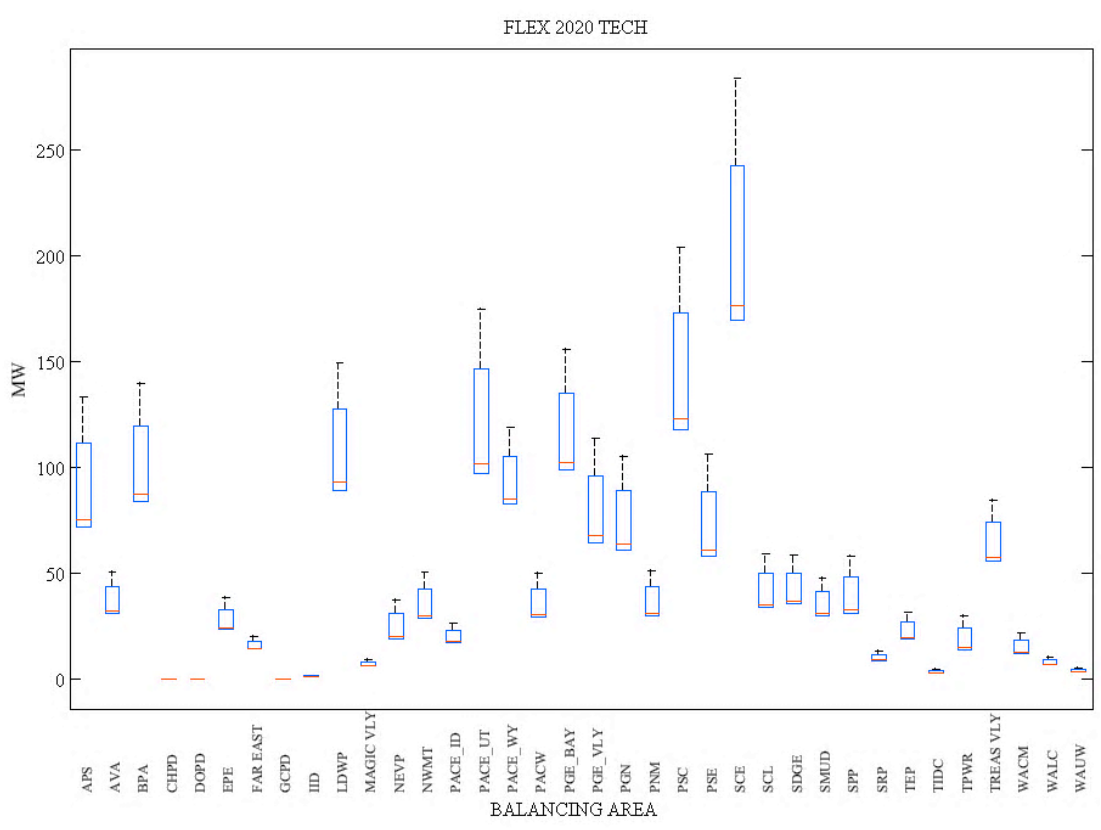

Figure 3.12 Flex Availability by MW per BAA (Scenario 2) 


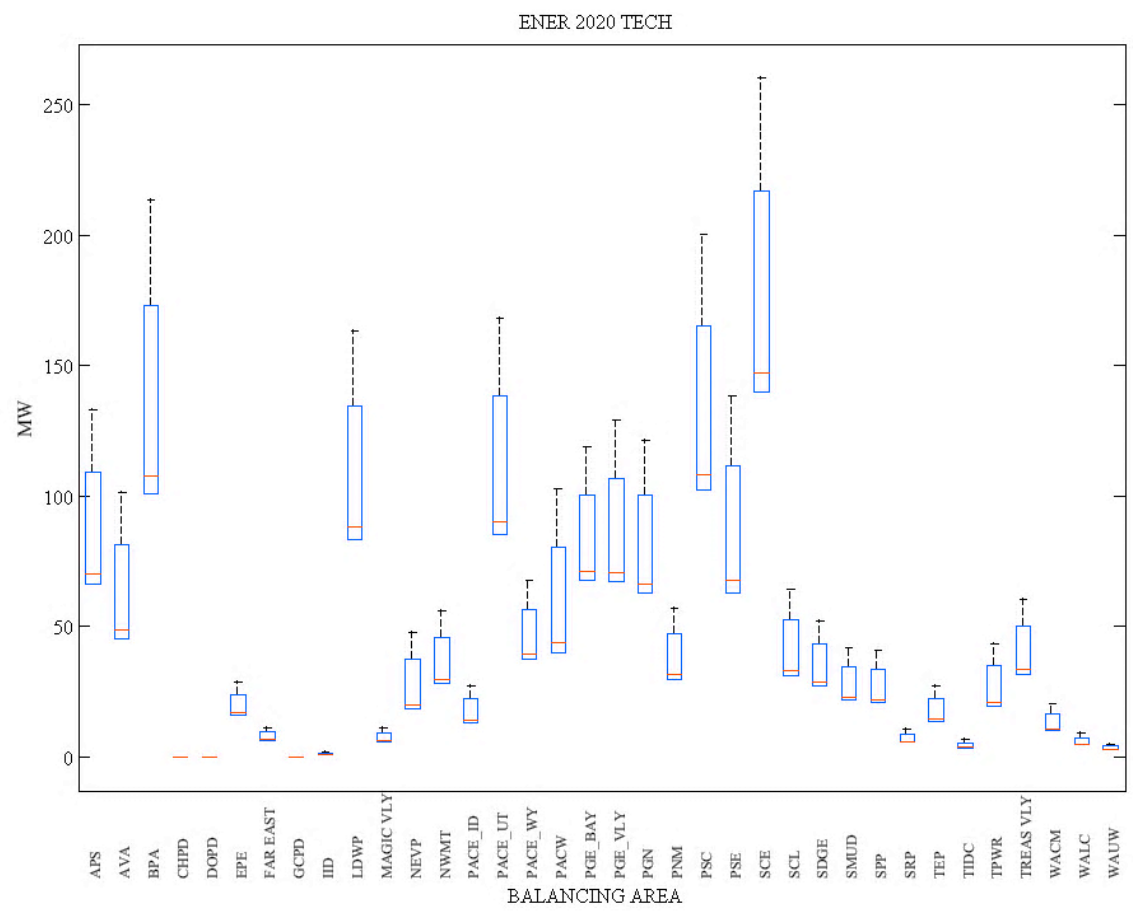

Figure 3.13 Energy Availability by MW per BAA (Scenario 2)

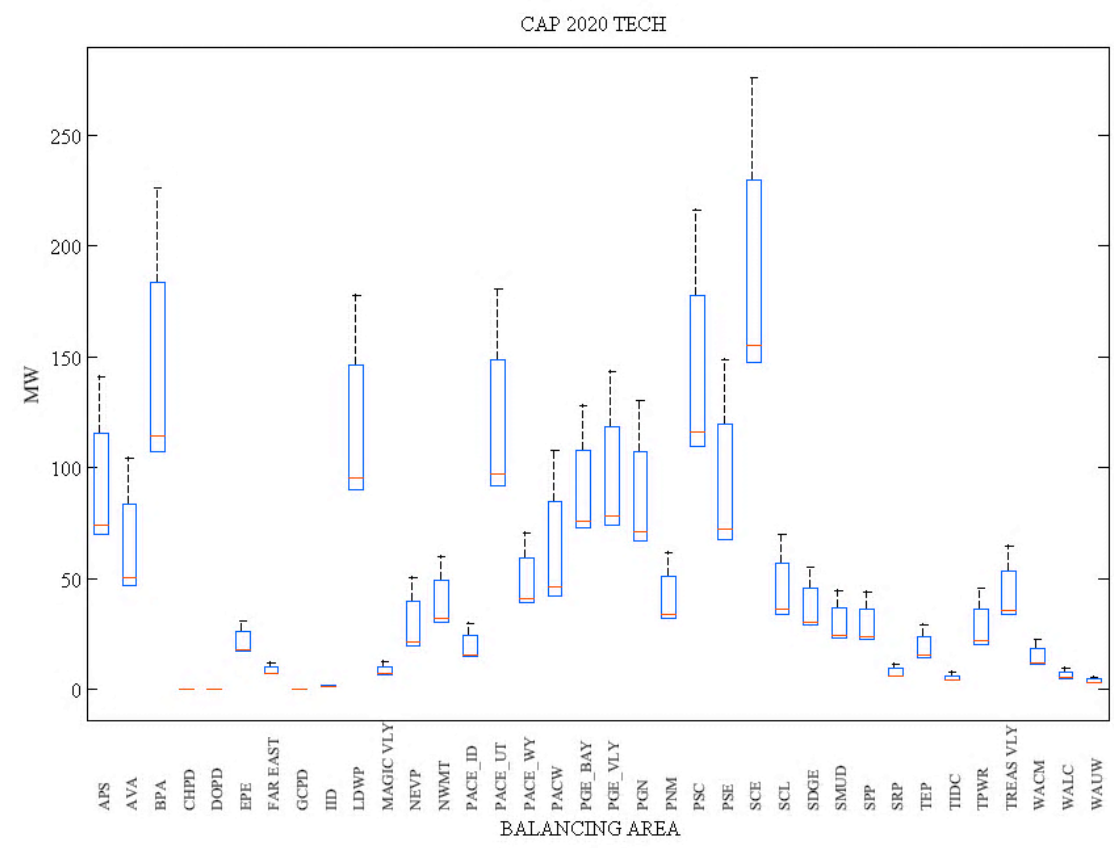

Figure 3.14 Capacity Availability by MW per BAA (Scenario 2) 
Figure 3.15 represents the aggregated hourly industrial load profiles of the distinct four-digit SIC manufacturing plants available in each BA of the $\mathrm{WI}$ region as determined by the IGATE-E@. These profiles were derived from the electricity consumption information, load factor information, and peak information derived for each plant in the $\mathrm{Wl}$ area using bottom up approach as explained in details in Appendix A and Appendix B.

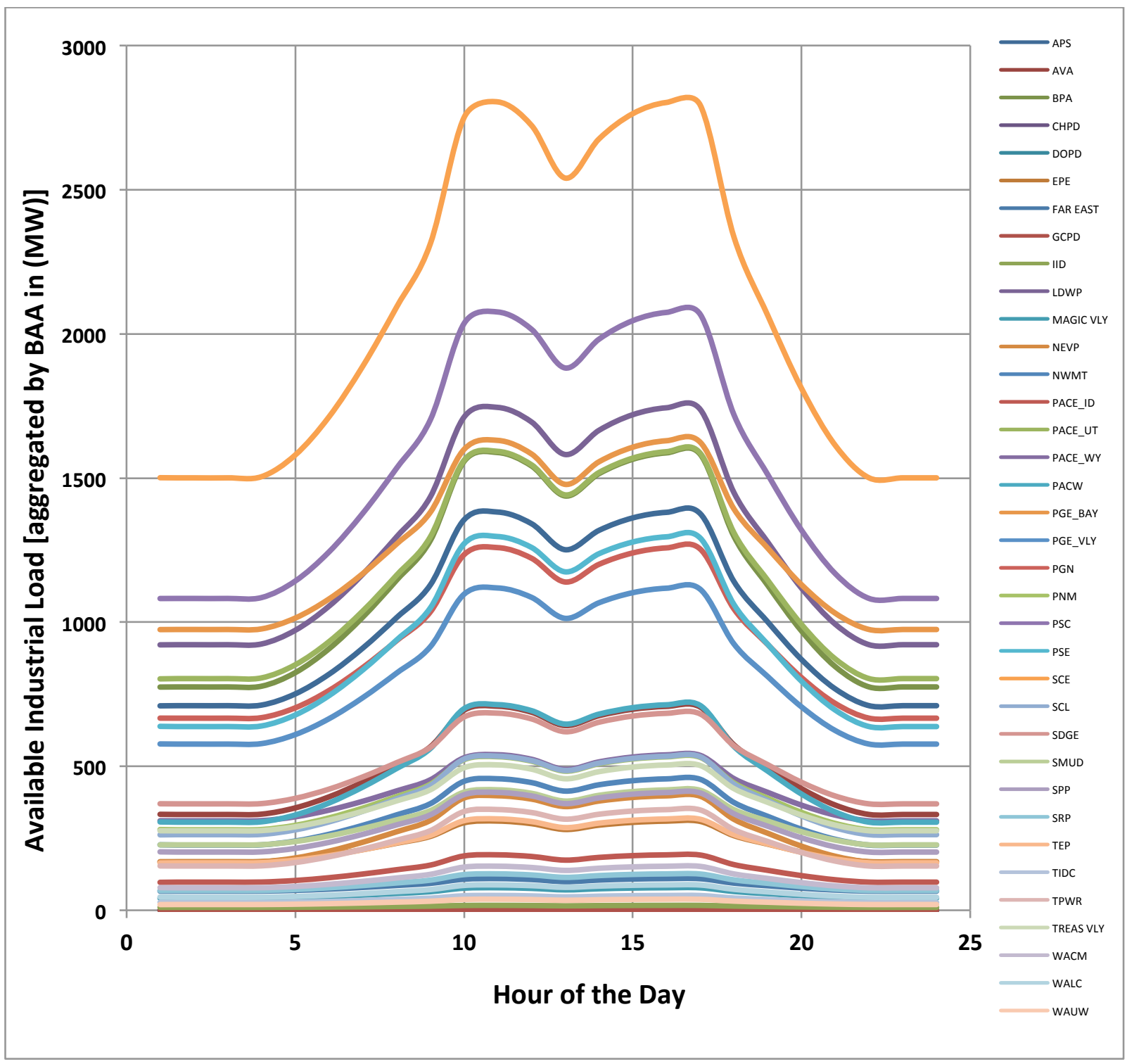

Figure 3.15 Hourly Aggregated Industrial Load Curves (458 Four-Digit SICs representing 458 industrial subsectors) broken by each BAA in Western Interconnect Region (WI) 
The following sets of tables summarize the DR product capabilities by balancing area (BAAA). It also summarizes the estimated availability as well as peak, cumulative and technical potential for the different DR products by balancing area within the Western Interconnect.

Table 3.1 Summary of Product capabilities, by Balancing Authority Area

\begin{tabular}{|c|c|c|c|c|c|}
\hline \multirow[b]{2}{*}{ BAA } & \multicolumn{5}{|c|}{ Product availability relative to total load: Min\%-Max\% (Avg\%) } \\
\hline & Regulation & Flexibility & Contingency & Energy & Capacity \\
\hline APS & $0.57-0.62(0.6)$ & $2.57-2.81(2.72)$ & $2.53-2.78(2.69)$ & $2.06-2.12(2.1)$ & $2.17-2.22(2.2)$ \\
\hline AVA & $0.54-0.76(0.68)$ & $2.12-2.93(2.63)$ & $2.08-2.89(2.59)$ & $2.75-2.92(2.86)$ & $2.83-3(2.94)$ \\
\hline BPA & $0.72-0.95(0.87)$ & $2.58-3.36(3.07)$ & $2.53-3.32(3.03)$ & $2.69-2.85(2.79)$ & $2.84-2.99(2.94)$ \\
\hline CHPD & $0-0(0)$ & $0-0(0)$ & $0-0(0)$ & $0-0(0)$ & $0-0(0)$ \\
\hline DOPD & $0-0(0)$ & $0-0(0)$ & $0-0(0)$ & $0-0(0)$ & $0-0(0)$ \\
\hline EPE & $1-1.14(1.09)$ & $3.94-4.73(4.45)$ & $3.66-4.33(4.09)$ & $2.13-2.36(2.27)$ & $2.28-2.53(2.44)$ \\
\hline Far East & $1.92-2.4(2.23)$ & $6.23-7.62(7.13)$ & $6.13-7.5(7.02)$ & $2.55-2.71(2.66)$ & 2.73-2.86(2.81) \\
\hline GCPD & $0-0(0)$ & $0-0(0)$ & $0-0(0)$ & $0-0(0)$ & $0-0(0)$ \\
\hline IID & $0.8-0.91(0.87)$ & $2.88-3.08(3.01)$ & $2.8-3.04(2.95)$ & $2.14-2.28(2.19)$ & $2.39-2.56(2.45)$ \\
\hline LDWP & $0.58-0.66(0.63)$ & $2.49-2.93(2.77)$ & $2.4-2.79(2.65)$ & $1.91-1.99(1.96)$ & $2.05-2.13(2.1)$ \\
\hline Magic Vly. & $1.05-1.38(1.26)$ & $3.45-4.46(4.09)$ & $3.41-4.4(4.04)$ & $2.85-3.05(2.98)$ & $3.18-3.38(3.31)$ \\
\hline NEVP & $0.6-0.78(0.71)$ & $2.44-3.16(2.89)$ & $2.42-3.12(2.86)$ & $2.25-2.26(2.25)$ & $2.37-2.39(2.38)$ \\
\hline NWMT & $0.69-0.81(0.77)$ & $3.04-3.76(3.5)$ & $2.87-3.5(3.27)$ & $2.37-2.58(2.5)$ & $2.55-2.78(2.69)$ \\
\hline PACE_ID & $1.27-1.79(1.6)$ & $4.23-5.8(5.23)$ & $4.17-5.72(5.16)$ & $2.88-3.08(3.01)$ & $3.15-3.34(3.27)$ \\
\hline PACE_UT & $0.8-0.94(0.89)$ & 3.23-3.79(3.59) & $3.11-3.63(3.44)$ & $2.26-2.43(2.37)$ & $2.41-2.58(2.52)$ \\
\hline PACE_WY & $2.28-2.95(2.71)$ & $7.69-9.68(8.97)$ & $7.55-9.51(8.81)$ & $3.13-3.39(3.3)$ & $3.24-3.49(3.4)$ \\
\hline PACW & $0.53-0.78(0.69)$ & $1.99-2.92(2.57)$ & $1.96-2.88(2.53)$ & $2.52-2.56(2.54)$ & $2.66-2.68(2.67)$ \\
\hline PGE Bay & $0.78-0.87(0.83)$ & $2.9-3.19(3.09)$ & $2.85-3.14(3.04)$ & $1.71-1.73(1.72)$ & $1.8-1.82(1.81)$ \\
\hline PGE Vly. & $0.6-0.69(0.66)$ & $2.57-2.98(2.83)$ & $2.51-2.9(2.76)$ & $2.29-2.41(2.37)$ & $2.52-2.64(2.6)$ \\
\hline PGN & $0.57-0.64(0.62)$ & $2.34-2.68(2.56)$ & $2.26-2.59(2.47)$ & $2.02-2.11(2.08)$ & $2.15-2.23(2.2)$ \\
\hline PNM & $0.62-0.77(0.72)$ & $2.56-3.04(2.86)$ & $2.51-2.98(2.81)$ & $2.16-2.28(2.24)$ & $2.33-2.44(2.4)$ \\
\hline PSC & $0.65-0.78(0.74)$ & $2.71-3.18(3.01)$ & $2.66-3.12(2.96)$ & $1.98-2.07(2.04)$ & $2.11-2.19(2.16)$ \\
\hline PSE & $0.49-0.58(0.54)$ & $2.28-2.74(2.57)$ & $2.14-2.53(2.39)$ & $2.11-2.12(2.12)$ & $2.26-2.27(2.26)$ \\
\hline SCE & $0.65-0.74(0.71)$ & $2.81-3.22(3.07)$ & $2.77-3.18(3.04)$ & $2.04-2.16(2.12)$ & $2.13-2.25(2.21)$ \\
\hline SCL & $0.54-0.62(0.59)$ & $2.71-3.27(3.06)$ & $2.59-3.08(2.9)$ & $2.37-2.48(2.44)$ & $2.57-2.7(2.65)$ \\
\hline SDGE & $0.56-0.65(0.62)$ & $2.47-2.86(2.72)$ & $2.43-2.82(2.68)$ & $1.61-1.67(1.65)$ & 1.69-1.74(1.72) \\
\hline SMUD & $0.88-1.09(1.01)$ & $3.41-4.13(3.87)$ & $3.36-4.07(3.82)$ & $2.2-2.27(2.24)$ & $2.32-2.39(2.36)$ \\
\hline SPP & $0.84-0.96(0.92)$ & $3.66-4.16(3.98)$ & $3.61-4.1(3.92)$ & $2.14-2.29(2.24)$ & $2.28-2.43(2.38)$ \\
\hline SRP & $0.99-1.35(1.22)$ & $3.46-4.57(4.17)$ & $3.41-4.5(4.11)$ & $1.87-2.04(1.98)$ & $1.95-2.1(2.05)$ \\
\hline TEP & $0.76-0.94(0.88)$ & $2.89-3.45(3.25)$ & $2.84-3.4(3.2)$ & $1.79-1.84(1.82)$ & $1.89-1.93(1.92)$ \\
\hline TIDC & $0.65-0.78(0.74)$ & $2.13-2.51(2.37)$ & $2.1-2.49(2.35)$ & $2.47-2.66(2.59)$ & $2.82-3.03(2.95)$ \\
\hline TPWR & $0.47-0.53(0.49)$ & $2.35-2.6(2.51)$ & 2.23-2.41(2.35) & $2.6-2.93(2.81)$ & $2.71-3.05(2.92)$ \\
\hline Treas. & $1.7-2.22(2.03)$ & $5.66-7.21(6.65)$ & $5.57-7.1(6.55)$ & $2.78-2.97(2.9)$ & $2.92-3.09(3.03)$ \\
\hline WACM & $0.98-1.21(1.12)$ & $3.9-4.72(4.42)$ & $3.69-4.4(4.14)$ & $2.67-2.81(2.76)$ & $2.98-3.12(3.07)$ \\
\hline WALC & $1.05-1.42(1.28)$ & $3.82-4.97(4.55)$ & $3.75-4.89(4.47)$ & $2.31-2.56(2.47)$ & $2.43-2.67(2.58)$ \\
\hline WAUW & $1.02-1.42(1.28)$ & $3.69-4.88(4.45)$ & $3.62-4.8(4.37)$ & $2.57-2.83(2.74)$ & $2.85-3.11(3.01)$ \\
\hline
\end{tabular}


Table 3.2 Estimated Availability, Peak and Cumulative, and Technical Potential - Regulation

\begin{tabular}{|c|c|c|c|c|c|c|}
\hline \multirow{2}{*}{ Region } & \multicolumn{2}{|c|}{ Estimated Availability } & \multicolumn{2}{|c|}{ Technical Potential } & \multirow{2}{*}{$\begin{array}{c}\text { Estimated } \\
\text { Cumulative } \\
\text { Availability (GWh) }\end{array}$} & \multirow{2}{*}{$\begin{array}{c}\text { Cumulative } \\
\text { Technical Potential } \\
\text { (GWh) }\end{array}$} \\
\hline & $\begin{array}{c}\text { Min } \\
\text { (MW) }\end{array}$ & $\begin{array}{l}\text { Max } \\
\text { (MW) }\end{array}$ & $\begin{array}{l}\text { Min } \\
\text { (MW) }\end{array}$ & $\begin{array}{l}\text { Max } \\
\text { (MW) }\end{array}$ & & \\
\hline Arizona & 8 & 12 & 23 & 40 & 80 & 249 \\
\hline California North & 15 & 24 & 47 & 78 & 156 & 497 \\
\hline California South & 20 & 33 & 61 & 104 & 208 & 653 \\
\hline Colorado & 9 & 15 & 30 & 51 & 99 & 318 \\
\hline Idaho & 10 & 14 & 28 & 41 & 99 & 280 \\
\hline Montana & 2 & 4 & 7 & 13 & 23 & 76 \\
\hline Nevada & 2 & 3 & 6 & 12 & 21 & 72 \\
\hline Nevada South & 1 & 2 & 4 & 9 & 14 & 49 \\
\hline New Mexico & 4 & 6 & 13 & 22 & 42 & 136 \\
\hline Northwest & 23 & 38 & 73 & 128 & 240 & 788 \\
\hline Utah & 8 & 13 & 23 & 41 & 81 & 252 \\
\hline Wyoming & 9 & 12 & 24 & 34 & 89 & 237 \\
\hline $\begin{array}{c}\text { Total - Western } \\
\text { Interconnect }\end{array}$ & 111 & 176 & 339 & 573 & 1151 & 3607 \\
\hline
\end{tabular}

Table 3.3 Estimated Availability, Peak and Cumulative, and Technical Potential - Flexibility

\begin{tabular}{|c|c|c|c|c|c|c|}
\hline \multirow[t]{2}{*}{ Region } & \multicolumn{2}{|c|}{ Estimated Availability } & \multicolumn{2}{|c|}{ Technical Potential } & \multirow{2}{*}{$\begin{array}{c}\text { Estimated } \\
\text { Cumulative } \\
\text { Availability } \\
\text { (GWh) }\end{array}$} & \multirow{2}{*}{$\begin{array}{c}\text { Cumulative } \\
\text { Technical Potential } \\
\text { (GWh) }\end{array}$} \\
\hline & $\begin{array}{c}\text { Min } \\
(\mathrm{MW})\end{array}$ & $\begin{array}{l}\text { Max } \\
\text { (MW) }\end{array}$ & $\begin{array}{c}\text { Min } \\
(\mathrm{MW})\end{array}$ & $\begin{array}{c}\text { Max } \\
\text { (MW) }\end{array}$ & & \\
\hline Arizona & 31 & 52 & 106 & 189 & 326 & 1153 \\
\hline California North & 57 & 90 & 196 & 321 & 591 & 2058 \\
\hline California South & 84 & 137 & 295 & 493 & 882 & 3126 \\
\hline Colorado & 37 & 61 & 130 & 226 & 391 & 1399 \\
\hline Idaho & 32 & 46 & 93 & 141 & 317 & 943 \\
\hline Montana & 9 & 14 & 32 & 55 & 93 & 343 \\
\hline Nevada & 8 & 15 & 31 & 58 & 90 & 344 \\
\hline Nevada South & 5 & 10 & 19 & 37 & 58 & 216 \\
\hline New Mexico & 16 & 25 & 53 & 89 & 162 & 565 \\
\hline Northwest & 89 & 147 & 310 & 541 & 940 & 3347 \\
\hline Utah & 29 & 50 & 97 & 174 & 312 & 1061 \\
\hline Wyoming & 30 & 41 & 83 & 119 & 288 & 820 \\
\hline $\begin{array}{c}\text { Total - Western } \\
\text { Interconnect* }\end{array}$ & 427 & 688 & 1445 & 2443 & 4451 & 15375 \\
\hline
\end{tabular}

Table 3.4 Estimated Availability, Peak and Cumulative, and Technical Potential - Contingency

\begin{tabular}{|c|c|c|c|c|c|c|}
\hline \multirow[t]{2}{*}{ Region } & \multicolumn{2}{|c|}{ Estimated Availability } & \multicolumn{2}{|c|}{ Technical Potential } & \multirow{2}{*}{$\begin{array}{l}\text { Estimated } \\
\text { Cumulative } \\
\text { Availability }\end{array}$} & \multirow{2}{*}{$\begin{array}{c}\text { Cumulative } \\
\text { Technical } \\
\text { Potential }\end{array}$} \\
\hline & Min & $\operatorname{Max}$ & Min & Max & & \\
\hline Arizona & 31 & 52 & 107 & 191 & 331 & 1166 \\
\hline California North & 58 & 92 & 199 & 326 & 602 & 2089 \\
\hline California South & 86 & 140 & 300 & 502 & 902 & 3180 \\
\hline Colorado & 38 & 62 & 132 & 230 & 400 & 1424 \\
\hline Idaho & 33 & 46 & 94 & 142 & 321 & 956 \\
\hline Montana & 10 & 15 & 33 & 57 & 99 & 359 \\
\hline Nevada South & 5 & 10 & 19 & 38 & 59 & 218 \\
\hline New Mexico & 16 & 26 & 55 & 92 & 170 & 586 \\
\hline Northwest & 93 & 152 & 319 & 554 & 974 & 3437 \\
\hline Utah & 31 & 51 & 100 & 179 & 325 & 1096 \\
\hline Wyoming & 30 & 42 & 84 & 121 & 294 & 834 \\
\hline $\begin{array}{l}\text { Total - Western } \\
\text { Interconnect }\end{array}$ & 439 & 703 & 1473 & 2490 & 4568 & 15694 \\
\hline
\end{tabular}


Table 3.5 Estimated Availability and Technical Potential of Energy and Capacity Products

\begin{tabular}{|c|c|c|c|c|c|c|}
\hline \multirow[t]{2}{*}{ BAA } & \multirow{2}{*}{$\begin{array}{c}\text { Estimated } \\
\text { Capacity } \\
\text { (MW) }\end{array}$} & \multirow{2}{*}{$\begin{array}{c}\text { Technical } \\
\text { Potential } \\
\text { Capacity } \\
\text { (MW) }\end{array}$} & \multicolumn{2}{|c|}{$\begin{array}{c}\text { Estimated Energy Shift } \\
\text { Availability }\end{array}$} & \multicolumn{2}{|c|}{ Technical Potential Energy Shif } \\
\hline & & & Min (MWH) & $\begin{array}{c}\text { Max } \\
\text { (MWH) }\end{array}$ & $\begin{array}{c}\text { Min } \\
\text { (MWH) }\end{array}$ & $\begin{array}{c}\text { Max } \\
\text { (MWH) }\end{array}$ \\
\hline APS & 30 & 141 & 7.78 & 43.1 & 32.58 & 188.56 \\
\hline AVA & 20 & 104 & 6.03 & 38.56 & 27.88 & 202.71 \\
\hline BPA & 45 & 226 & 13.59 & 79.12 & 60.33 & 387.12 \\
\hline CHPD & 0 & 0 & 0 & 0 & 0 & 0 \\
\hline DOPD & 0 & 0 & 0 & 0 & 0 & 0 \\
\hline EPE & 7 & 31 & 2.37 & 11.49 & 8.76 & 44.36 \\
\hline Far East & 3 & 12 & 1.44 & 6.99 & 4.49 & 21.61 \\
\hline GCPD & 0 & 0 & 0 & 0 & 0 & 0 \\
\hline IID & 0 & 2 & 0.13 & 0.63 & 0.57 & 2.64 \\
\hline LDWP & 36 & 178 & 9.76 & 53 & 41.37 & 230.53 \\
\hline Magic Vly. & 2 & 12 & 0.81 & 3.84 & 3.43 & 15.95 \\
\hline NEVP & 9 & 51 & 2.13 & 15.62 & 9.95 & 82.37 \\
\hline NWMT & 12 & 60 & 3.22 & 17.54 & 14.93 & 86.23 \\
\hline PACE ID & 6 & 30 & 2.1 & 11.26 & 8.3 & 46.83 \\
\hline PACE_UT & 38 & 181 & 11.7 & 64.39 & 48.04 & 272.05 \\
\hline PACE_WY & 18 & 71 & 8.42 & 46.05 & 26.31 & 152.18 \\
\hline PACW & 19 & 108 & 5.01 & 37.98 & 25.01 & 209.55 \\
\hline PGE Bay & 29 & 128 & 10.19 & 51.18 & 36.77 & 184.33 \\
\hline PGE Vly. & 28 & 143 & 7.08 & 35.64 & 32.85 & 168.12 \\
\hline PGN & 27 & 130 & 7.84 & 40.95 & 33.85 & 187.77 \\
\hline PNM & 12 & 62 & 3.64 & 18.85 & 16.23 & 86.32 \\
\hline PSC & 44 & 216 & 12.88 & 69 & 55.13 & 303.32 \\
\hline PSE & 30 & 149 & 7.39 & 47 & 34.1 & 234.03 \\
\hline SCE & 60 & 276 & 15.34 & 83.13 & 61.24 & 342.36 \\
\hline SCL & 14 & 70 & 3.27 & 18.18 & 15.16 & 90.16 \\
\hline SDGE & 12 & 55 & 3.35 & 19.8 & 13.66 & 81.75 \\
\hline SMUD & 10 & 45 & 3.05 & 16.82 & 11.56 & 67.01 \\
\hline SPP & 9 & 44 & 2.21 & 12.09 & 8.94 & 49.34 \\
\hline SRP & 2 & 11 & 1.08 & 6.31 & 3.98 & 24.59 \\
\hline TEP & 6 & 29 & 1.85 & 10.87 & 7.7 & 46.43 \\
\hline TIDC & 1 & 8 & 0.39 & 1.68 & 1.86 & 7.97 \\
\hline TPWR & 9 & 45 & 2.24 & 13.05 & 9.92 & 67 \\
\hline Treas. Vly. & 15 & 64 & 6.29 & 34.88 & 21.77 & 126.72 \\
\hline WACM & 5 & 23 & 1.27 & 5.92 & 5.34 & 25.14 \\
\hline WALC & 2 & 10 & 0.81 & 4.57 & 3 & 17.9 \\
\hline WAUW & 1 & 6 & 0.38 & 1.88 & 1.61 & 7.98 \\
\hline
\end{tabular}




\section{Chapter 4 CONCLUSIONS, AND FUTURE RESEARCH}

\subsection{Conclusions}

We have conducted a detailed investigation using bottom up approaches for estimating load capabilities to deliver demand response products within the industrial sector located in the Western Interconnect Region. Our results provide an initial estimate of the magnitude of bulk power system services available from end-use loads by the two-digit SIC sectors. We provide an open and clear approach to predicting the availability of loads that is as datadriven as possible. By design, the profiles are results of aggregations of data driven electricity estimations, load factor estimations, peak estimations, and flexibility assumptions. These results were validated at a high level where possible. Comparisons of overall electricity estimations against DOE-EIA state estimations had a relative error of $8 \%$. Electricity consumption estimations were also compared to the DOE-EIA estimations for the $\mathrm{WI}$ and found to have an error of $7 \%$. These results are the first significant efforts in producing any type of detail into the industrial space at this time. They are suitable for future scoping studies, and prioritization of future data gathering and analyses. The use of analysis criteria using "Sheddability", "Controllability", and "Acceptability" as qualitative and quantitative filters is novel, testable, and extensible to other regions in the US.

The resulting profiles from this report serve as input to the Energy Production Cost Model. We discuss the resulting valuation of DR, including characteristics of products are valued, in accompanying "results" reports. Our efforts to value load participation assess the potential and economic incentives for load to participate in the provision of capacity, energy, and ancillary services; however, they do not cover the regulatory and market aspects of load participation. These issues are discussed in a recently released report developed as part of this project, Market and Policy Barriers for Demand Response Providing Ancillary Services in U.S. Markets (Cappers et al. 2013).

\subsection{Future Research}

The following highlights our vision to future research:

- The analyses in this report were mainly focused on the two-digit SIC level. As a future research, the focus should be expanded to the processes at the four-digit SIC level including the examination of end-use flexibility. This will provide a more accurate representation of flexibility and DR product availability.

- As a future research, experimental field testing of the end-uses covered in this report may be considered to practically quantify their response characteristics and flexibility of these resources.

- $\quad$ Although, seasonality effect may not play a significant role in many industries when looking at the manufacturing process loads (MPLs), this should be considered especially in plants with large HVAC loads as this may change the overall consumption.

- Plant operations are considered in this study to be continuous with the same load 
curve is applied throughout the year. In the real world, manufacturing processes may be down for modifications, model changes, maintenance activities or breakdown and input resources may not be available during particular periods requiring temporary plant shutdown. This variability in operational schedule may need to be taken into consideration in the future studies by adding methodologies to account for such events.

- $\quad$ Process steps per SIC are standardized to develop a representation by industry. Each plant may have different operational scheme that may impact electrical energy consumption profile, but in this study, this level of detail cannot be achieved. In future studies, provisions need to be put to take this into consideration.

\section{REFERENCES}

- US Energy Information Administration DOE-EIA 2012.

http://www.eia.gov/oiaf/aeo/tablebrowser/\#release=AEO2012\&subject=0-

AEO2012\&table=62-AEO2012\&region=3-19\&cases=ref2012-d020112c

- Brown, H., Hedman, B., Energy Analysis of 108 Industrial Processes, The Fairmont

Press, Inc., 1996

- Masiello R., K. Vu, L. Deng, A. Abrams, K. Corfee and J. Harrison, KEMA, Inc., D. Hawkins and Y. Kunjal, California Independent System Operator Corp., Research Evaluation of Wind and Solar Generation, Storage Impact, and Demand Response on the California Grid. Prepared for the California Energy Commission. 2010, CEC5002010-010

- Table C7. Industrial Sector Energy Consumption Estimates-2011 http://www.eia.gov/state/seds/data.cfm?incfile=/state/seds/sep_sum/html/sum_btu_i nd.html\&sid=US

- U.S. Department of Energy, Load Participation in Ancillary Services, 2011.

- Alkadi, N., M. Starke, O. Ma, K. Dowling, B. Johnson, S. Khan, S. Nimbalkar, D. Cox, "IGATE-E@ (Industrial Geospatial Analysis Tool for Energy Evaluation)," 35th Industrial Energy Technology Conference, (Accepted December 2012, Awaiting Publication in May 2013)

- $\quad$ O. Ma, Alkadi, N., P. Cappers, P. Denholm, J. Dudley, S. Goli. M. Hummon, S. Kilicotte, J. MacDonald, N. Matson, D. Olsen, C. Rose, M. Sohn, M. Starke, B. Kirby, M. O'Malley, “Demand Response for Ancillary Services,” IEEE Transactions on Real Time Demand response,"(Accepted October 2012, Awaiting Publication) 
- DOE-EIA MECS-2006. "Number of Establishments by Participation in General Energy-Management Activities, 2006." (Table 8.1) http://www.eia.gov/emeu/mecs/mecs2006/pdf/Table8_1.pdf

- Load Participation in Ancillary Services, U.S. Department of Energy, 2011.

- Census [online] Available at: http://www.census.gov

- NAICS Association [online] Available at: http://www.naics.com/search.htm

- US Census Bureau. 2007 Economic Census, "Manufacturing: Industry Series: Detailed Statistics by Industry for the United States." EC0731/1.

- Industrial Assessment Center Database. [Online]. Available: http: //iac.rutgers.edu/database/

- B. Gopalakrishnan, R. Plummer, N. Alkadi, "Comparison of Glass-Manufacturing Facilities Based on Energy Consumption and Plant Characteristics," The Journal of Energy and Development Vol. 27, Autumn 2001.

- National Manufacturers Databases by Industry. [Online]. Available: http://www.mnistore.com/

- Daniel J. Olsen, Nance Matson, Michael D. Sohn, Cody Rose, Junqiao Dudley, Sasank Goli, and Sila Kiliccote, Grid Integration of Aggregated Demand Response, Part 1: Load Availability Profiles and Constraints for the Western Interconnect, Lawrence Berkeley National Laboratory, 2013.

- Examination of the Potential for Industrial Loads to Provide Ancillary Services, Enbala Power Network, November 2012. 


\section{Abbreviations}

\begin{tabular}{|l|l|}
\hline BAA & Balancing Authority Area \\
\hline DR & Demand Response \\
\hline GWh & GigaWatt-hour, 1 GWh = 1000 MWh \\
\hline GA & Genetic Algorithms \\
\hline IGATE-E@ & Industrial Geospatial Analysis Tool for Energy Evaluation \\
\hline ORNL & Oak Ridge National Laboratory \\
\hline MW & MegaWatt, 1 MW = 1000 kW \\
\hline NREL & National Renewable Energy Laboratory \\
\hline RECS & Residential Energy Consumption Survey \\
\hline US DOE & United States Department of Energy \\
\hline WECC & Western Electricity Coordinating Council \\
\hline WI & Western Interconnect \\
\hline
\end{tabular}

\section{Balancing Authority Area (BAA) Abbreviations}

\begin{tabular}{|c|c|}
\hline APS & Arizona Public Service Company \\
\hline AVA & Avista Corporation \\
\hline BPA & Bonneville Power Administration \\
\hline CHPD & PUD No. 1 of Chelan County \\
\hline DOPD & PUD No. 1 of Douglas County \\
\hline EPE & El Paso Electric Company \\
\hline Far East & Idaho Power - Far East Region \\
\hline GCPD & PUD No. 2 of Grant County \\
\hline IID & Imperial Irrigation District \\
\hline LDWP & Los Angeles Department of Water and Power \\
\hline Magic Vly. & Idaho Power - Magic Valley Region \\
\hline NEVP & Nevada Power Company \\
\hline NWMT & NorthWestern Energy \\
\hline PACE ID & PacifiCorp East - Idaho \\
\hline PACE UT & PacifiCorp East - Utah \\
\hline PACE_WY & PacifiCorp East - Wyoming \\
\hline PACW & PacifiCorp West \\
\hline PGE Bay & Pacific Gas and Electric Company - San Francisco Bay Area \\
\hline PGE Vly. & Pacific Gas and Electric Company - Central Valley \\
\hline PGN & Portland General Electric Company \\
\hline PNM & Public Service Company of New Mexico \\
\hline PSC & Public Service Company of Colorado \\
\hline PSE & Puget Sound Energy \\
\hline SCE & Southern California Edison \\
\hline SCL & Seattle City Light \\
\hline SDGE & San Diego Gas and Electric \\
\hline SMUD & Sacramento Municipal Utilities District \\
\hline SPP & Sierra Pacific Power Company \\
\hline SRP & Salt River Project \\
\hline TEP & Tucson Electric Power Company \\
\hline TIDC & Turlock Irrigation District \\
\hline TPWR & City of Tacoma, Department of Public Utilities \\
\hline Treas. Vly. & Idaho Power - Treasure Valley Region \\
\hline WACM & $\begin{array}{l}\text { Western Area Power Administration - Colorado-Missouri } \\
\text { Region }\end{array}$ \\
\hline WALC & Western Area Power Administration - Lower Colorado Region \\
\hline WAUW & $\begin{array}{l}\text { Western Area Power Administration - Upper Great Plains } \\
\text { West }\end{array}$ \\
\hline
\end{tabular}

Adapted from Western Interconnect Balancing Authorities (38).

http://www.WI.biz/library/WI\%2520Documents/Publications/WI BA Map.pdf 
Appendices 


\title{
APPENDIX A Industrial Energy Estimation Approach
}

\author{
Framework: Industrial Geospatial Analysis Tool for Energy Evaluation- IGATE-E@
}

\begin{abstract}
A.1 Abstract
IGATE-E $\odot$ is an industrial energy analysis tool. The tool is intended to be a decision support and planning tool to a wide spectrum of energy analysts, engineers, researchers, government organizations, private consultants, industry partners, and alike. The tool applies statistical modeling to multiple datasets and provides information at the geospatial resolution of zip code using bottom up approaches. Within each zip code, the current version of the tool estimates electrical energy consumption of manufacturing industries based on each type of industries using information from DOE's Industrial Assessment Center database (IAC-DB) and DOE's Energy Information Administration Manufacturing Energy Consumption Survey database (EIA-MECS DB), in addition to commercially available databases such as the Manufacturing News database (MNI, Inc.). Ongoing and future work include adding modules for the predictions of fuel energy consumption streams, manufacturing process steps energy consumption, major energy intensive processes (EIPs) within each industry type among other metrics of interest. The tool utilizes the DOE EIA-MECS energy survey data to validate bottom-up estimates and permits several statistical examinations.
\end{abstract}

\section{A.2 Introduction}

Energy professionals and researchers are often challenged with initiating projects or performing analyses that are the basis for project approval with limited and/or unreliable information. In manufacturing industry related projects, the challenge is compounded (compared to residential and commercial sectors) since end-use attributes in commercial and residential sectors are more uniform than in the industrial sector. In addition, data on some driving factors are more accessible, like temperature, population densities, or other parameters that are typically used for residential and commercial energy estimation models. Industrial energy consumption is heavily dependent on the type of manufacturing process, production volume, plant size, location, operational parameters, and other variables that are usually proprietary for each manufacturing facility.

We will discuss the development of an analytical tool "IGATE-E" (Industrial Geospatial Analysis Tool for Energy Evaluation) that provides multi-layer industrial energy information including; manufacturing plant level, industrial subsector level, zip code level, county level, balancing authority level, state level, and national level. IGATE-E was developed utilizing MATLAB platform as the existence of numerous tool libraries provides good opportunities for analysis expansion. It utilizes statistical analysis of multiple databases to estimate manufacturing plants energy consumption for over 300,000 manufacturers across the U.S. and provides geospatial interlinking to Google Earth using MATLAB based mapping tools. We used the "bottom up approach" in the development of this tool where the analyses were performed at the granular level of a manufacturing facility and results were aggregated up to zip code and regional values. The current version of the tool is only capable of estimation of electrical energy consumption; however, future versions of this tool will include estimation of fuel energy streams at the plant level as well as other parameters of interest such as Energy Intensive Processes per SIC, Load Curves per Process Step per SIC, Load Factor per type of Manufacturing Plant. Future versions can also be linked with other DOE tools such as LIGHTEnUP tool to provide the impact of implementing emerging energy 
efficiency (EE) technologies in industrial sector. The following sections describe the tool development methodology, initial results of the analysis, and brief introduction to the tool and its visualization capabilities.

\section{A.3 Tool Development Methodology}

Development of the current of version of the IGATE-E tool consisted of collecting and querying multiple datasets for industrial related information, data filtering, statistical modeling, computations, and validating the results against published DOE's EIA-MECS data. The tool performs multi-layer analysis and provides geospatial representations of different manufacturing sectors across the U.S. The following subsections describe this functional flow diagram in details.

\section{A.4 Database Querying}

As shown in Figure A.1, the manufacturing plants energy information (mainly small to medium and large size plants) datasets from previous industrial assessments were pulled using publicly available IAC database and Energy Saving Assessments data (ESA). Plant level energy information included industry types based on SIC (Standard Industrial Classification) and/or NAICS (North American Industry Classification System), energy systems, size of the plants in terms of square footage, number of staff employed, number of operating hours, average peak demand, electrical energy consumption, and product sales. The SIC codes (NAICS codes) classify establishments by their primary activity [4]. Although, IGATE-E is an SIC based tool, linking old data on an SIC basis to new data on a NAICS basis is currently underway. As a matter of fact, data for more than two-thirds of all 4-digit SICs will be derivable from the NAICS system, either because the industry is not being changed (other than in code), or because new industries are being defined as subdivisions of old ones.

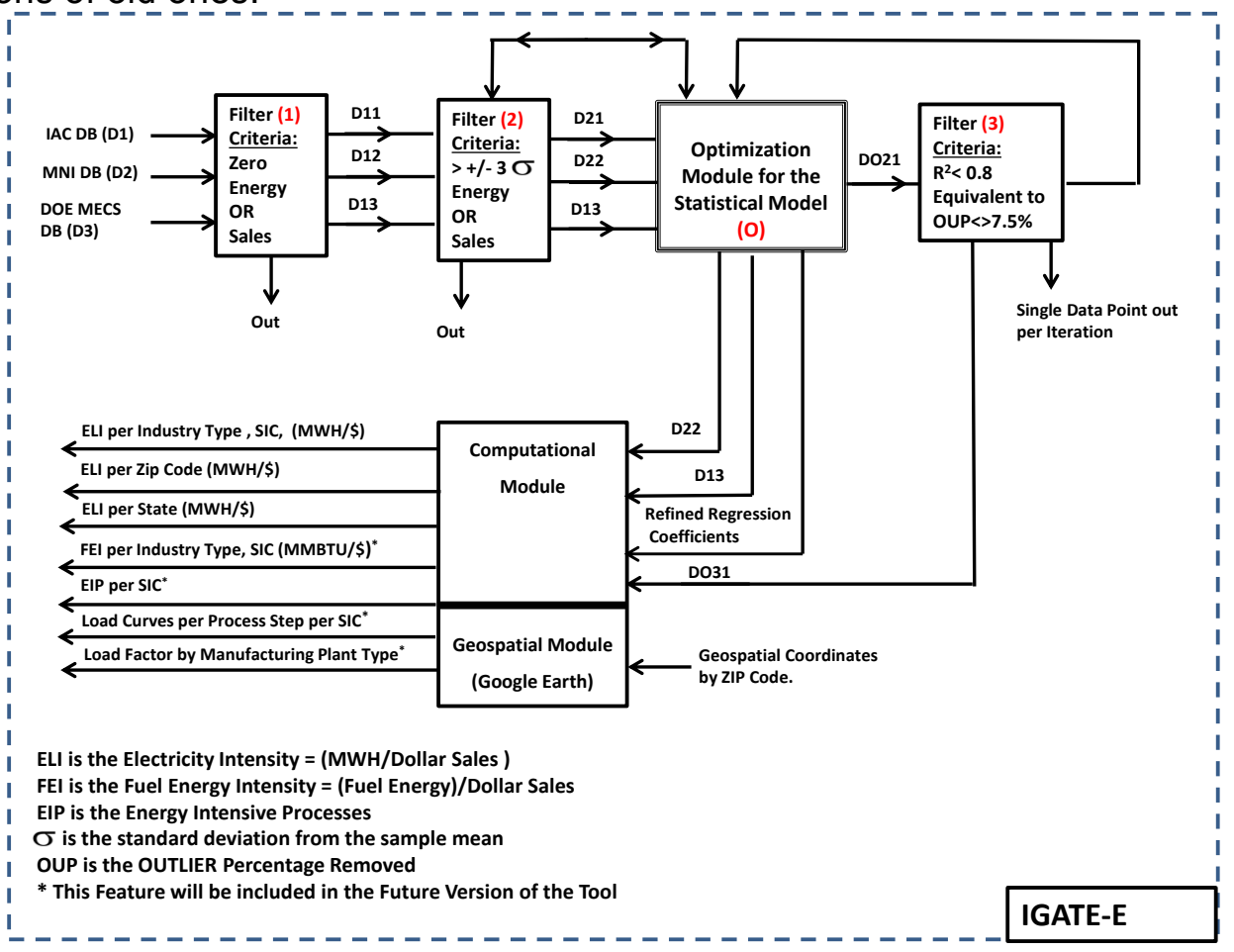

Figure A.1 IGATE-E Flow Diagram 
Table A.1 shows major industry groups within both classification systems. The IAC Database is a collection of publicly available assessments and energy saving recommendations performed by student engineers seeking graduate degrees under supervision of tenured faculty professors at selective number of US universities. Currently, there are 24 IACs located at accredited Universities across the US. These IACs are funded by the US Department of Energy as a means to promote industrial energy efficiency.

Table A.1 NAICS and SIC Relationship

\begin{tabular}{|c|c|c|c|}
\hline SIC & Major Industry Group & NAICS & $\begin{array}{l}\text { Major Industry } \\
\text { Subsector }\end{array}$ \\
\hline 20 & Food And Kindred Products & 311 & Food \\
\hline 21 & Tobacco Products & 3122 & Tobacco \\
\hline 22 & Textile Mill Products & 314 & Textile Product Mills \\
\hline 23 & $\begin{array}{l}\text { Apparel And Other Finished Products } \\
\text { Made From Fabrics And Similar } \\
\text { Materials }\end{array}$ & 315 & Apparel \\
\hline 24 & $\begin{array}{l}\text { Lumber And Wood Products, Except } \\
\text { Furniture }\end{array}$ & 316 & $\begin{array}{l}\text { Leather and Allied } \\
\text { Products }\end{array}$ \\
\hline 25 & Furniture And Fixtures & 321 & Wood Products \\
\hline 26 & Paper And Allied Products & 322 & Paper \\
\hline 27 & $\begin{array}{l}\text { Printing, Publishing, And Allied } \\
\text { Industries }\end{array}$ & 323 & $\begin{array}{l}\text { Printing and Related } \\
\text { Support }\end{array}$ \\
\hline 28 & Chemicals And Allied Products & 324 & $\begin{array}{l}\text { Petroleum and Coal } \\
\text { Products }\end{array}$ \\
\hline 29 & $\begin{array}{l}\text { Petroleum Refining And Related } \\
\text { Industries }\end{array}$ & 325 & Chemicals \\
\hline 30 & $\begin{array}{l}\text { Rubber And Miscellaneous Plastics } \\
\text { Products }\end{array}$ & 326 & $\begin{array}{l}\text { Plastics and Rubber } \\
\text { Products }\end{array}$ \\
\hline 31 & Leather And Leather Products & 327 & $\begin{array}{l}\text { Nonmetallic Mineral } \\
\text { Products }\end{array}$ \\
\hline 32 & $\begin{array}{l}\text { Stone, Clay, Glass, And Concrete } \\
\text { Products }\end{array}$ & 331 & Primary Metals \\
\hline 33 & Primary Metal Industries & 332 & $\begin{array}{l}\text { Fabricated Metal } \\
\text { Products }\end{array}$ \\
\hline 34 & $\begin{array}{l}\text { Fabricated Metal Products, Except } \\
\text { Machinery And Transportation } \\
\text { Equipment }\end{array}$ & 333 & Machinery \\
\hline 35 & $\begin{array}{l}\text { Industrial And Commercial Machinery } \\
\text { And Computer Equipment }\end{array}$ & 334 & $\begin{array}{l}\text { Computer and Electronic } \\
\text { Products }\end{array}$ \\
\hline 36 & $\begin{array}{l}\text { Electronic And Other Electrical } \\
\text { Equipment And Components, Except } \\
\text { Computer Equipment }\end{array}$ & 335 & $\begin{array}{l}\text { Electrical Equip., } \\
\text { Appliances, and } \\
\text { Components }\end{array}$ \\
\hline 37 & Transportation Equipment & 336 & $\begin{array}{l}\text { Transportation } \\
\text { Equipment }\end{array}$ \\
\hline 38 & $\begin{array}{l}\text { Measuring, Analyzing, And Controlling } \\
\text { Instruments. }\end{array}$ & 337 & $\begin{array}{l}\text { Furniture and Related } \\
\text { Products }\end{array}$ \\
\hline 39 & $\begin{array}{l}\text { Miscellaneous Manufacturing } \\
\text { Industries }\end{array}$ & 339 & Miscellaneous \\
\hline
\end{tabular}

The information contained within these assessments includes size, industry, energy usage, etc. in addition to details of energy saving opportunities (recommendations) such as type, energy and cost savings, and payback period. As of February, 2013, the IAC database contained 15,803 industrial energy assessments and 118,719 recommendations identified in various energy system areas such as HVAC, Steam, Process Heating, and Motor Driven systems. The information of particular interest within the IAC Database consisted of reported plant annual electrical energy consumption, plant average peak demand, product sales, and the industry code. Figure A.2 shows the represented industrial sectors captured by the IAC assessments. This chart provides an indication of the potential accuracy in the regression analysis. It is worth mentioning that the IAC-DB is regularly updated as new assessments are completed and added to the IAC-DB. Certainly, this should enhance the quality of regressions and curve fit for some industrial sectors in the future. 


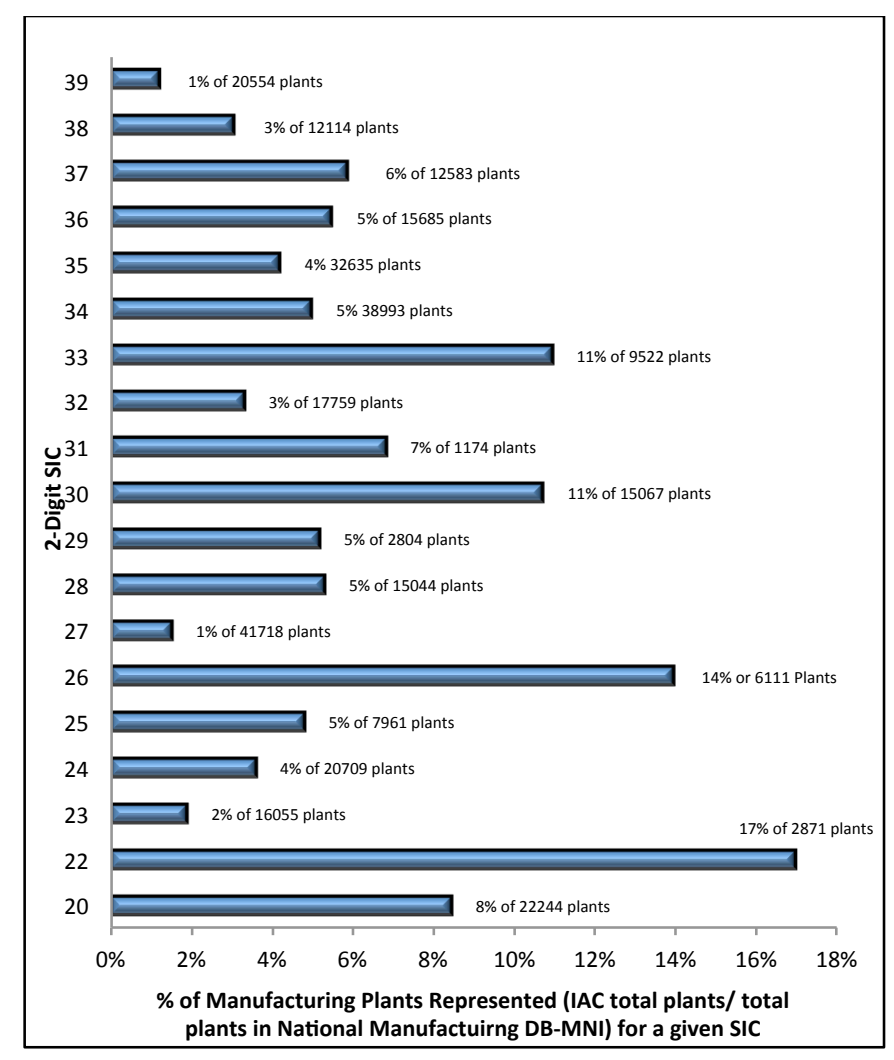

Figure A. 2 Percent of IAC Plants Modeled at the 2-Digit SIC Level

Manufacturing News, Inc Database (MNI) is a commercially available database which houses over 300,000 manufacturing plants entries and matches the official count by the US Census Bureau. The MNI database contains information on specific companies such as SIC (NAICS), plant name, type of products, product sales figures, zip code, mailing address, and company contacts. This information was gathered by MNI through phone calls and direct interviews with plants and companies personnel. EIA's 2006 Manufacturing Energy Consumption Survey (MECS - 2006) is a publicly available data on industry energy consumption. EIA's MECS 2006 data contain estimates of the number of establishments, average energy consumption by industry code and average energy costs by key industry code.

\section{A.5 Data Filtering Process}

Rigorous filtering processes of the data streams from the 3 primary databases used (IAC, $\mathrm{MNI}$, and EIA-MECS) were performed to eliminate potential outliers and enable regression models that are more representative of the actual data. It should be mentioned that data streams to IAC, MNI, and EIA-MECS were designated by 3 symbols; D1, D2, and D3. Figure A.1 shows three filters involved in this process as follows: 1) unreported energy and or sales removal filter, 2) standard deviation filter, and 3) outlier data point removal filter (OUP). Upon exiting each filter, data streams were associated by the given filter number to indicate whether or not a refinement process was applied to a given data stream. For example, data stream D13, denotes data sets that were only refined by Filter (1) with no further refinements required afterwards. We started with Filter (1) where all SICs that contain unreported energy or sales information were automatically removed and revised data streams (D11, D12, and D13) were ready to enter Filter 2 which is the Standard Deviation Filter. In this case, we applied a (+/-) $\mathrm{n} \sigma_{\text {of }}$ sales and electrical energy 
consumption, where $\mathrm{n} \sigma$ is the number of standard deviations as expressed by the following equations:

$$
\begin{aligned}
& \text { std_lim } \geq(y(i)-\bar{y}) / \operatorname{std}(y) \\
& S(i) \geq 0 \\
& E(i) \geq 0
\end{aligned}
$$

Where, $E$ represents energy in MWh, $S$ is the sales in dollars, and $y$ is the data value (either sales or energy). An optimization module helped determining the value of the variable $n$ to be 3 . This represents the optimum number of standard deviation where least error deviation occurs as shown in Figure A.3.

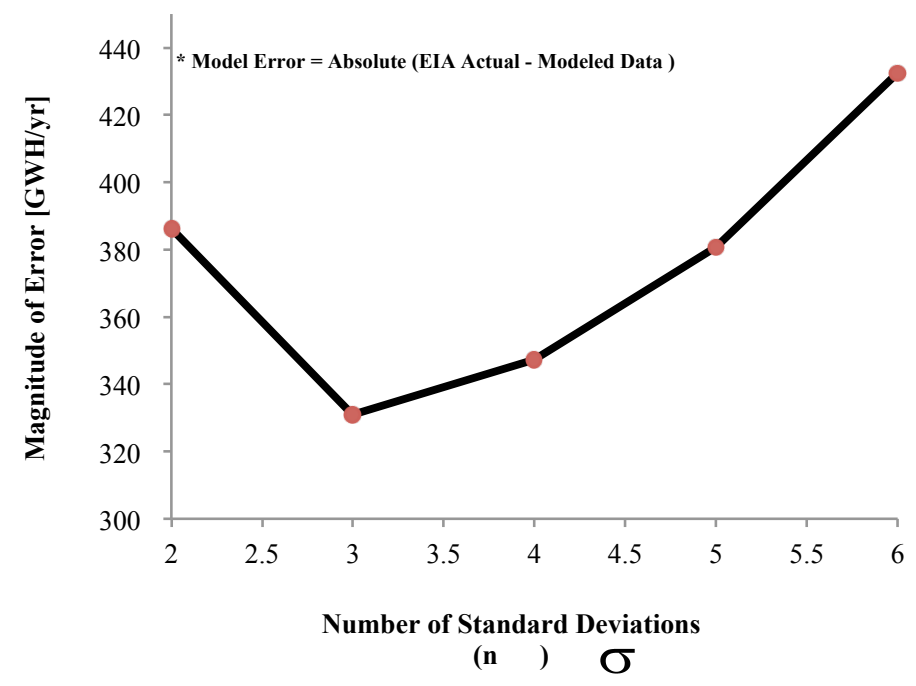

Figure A. 3. Magnitude of Model Error as a Function of Number of Standard Deviations from the Sample Mean

The optimization module is an iterative computational algorithm that optimizes the model accuracy by comparing the aggregate actual industrial electrical energy consumption in 50 states using published data from EIA-MECS DB (EIA Actual) with the aggregated modeled industrial energy consumption in the same states using IAC and MNI databases to filter out data points that generate higher error. As shown, model error is at its lowest when $n=3$.

Filter (3) was applied to remove certain percentage of problematic data that may affect the goodness of the model fit as represented by the $\mathrm{R}^{2}$ value (The coefficient of determination), Figure A.4. 


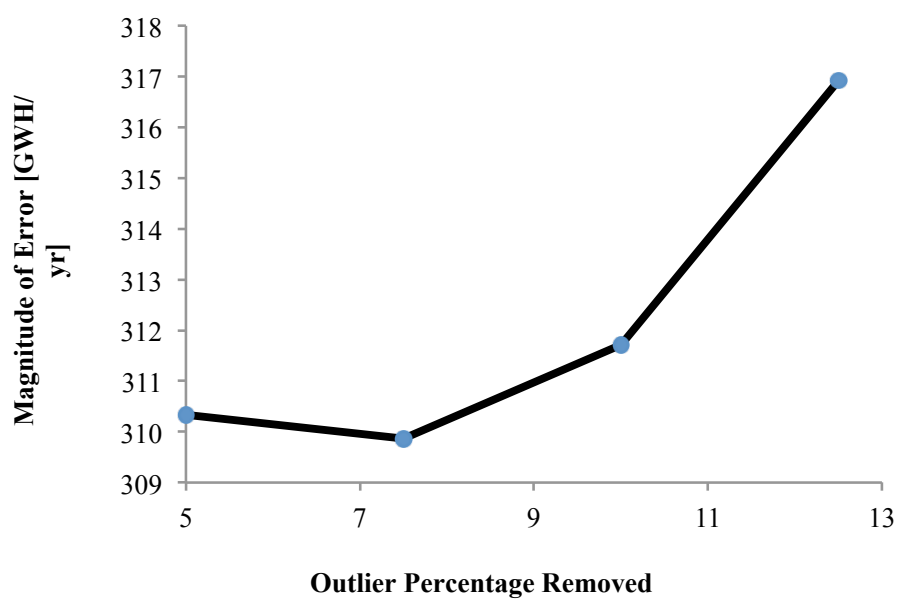

Figure A. 4 Magnitude of Model Error as a Function of the Outliers Removed (Percent of the Total Number of Data Points)

The outlier data points (OUP) were examined for removal. The strategy for this technique involved iteratively performing the linear regression with a single data point removed, examining the impact on $R^{2}$ value and taking the resulting highest $R^{2}$ value. For this analysis, we considered a threshold limit for $\mathrm{R}^{2}$ of 0.8 or higher as acceptable (Reference). Then, a correlation between $\mathrm{R}^{2}$ values and percentage of outlier data points removed (OUP) was established. Using the same optimization module explained above, it was found that at $7.2 \%$ of removed OUP, the model error is minimized.

It should be mentioned that the absolute magnitude of deviation in $\mathrm{GWH} / \mathrm{yr}$ shown in Figure A. 3 and A.4 is attributed to several factors including the number of represented industries in the EIA-MECS database as many industries may opt out of reporting their electrical energy consumption, hence some gaps in the data may exist. In addition, the quality of regressions may be impacted by shortage of data points in certain industrial sectors as shown in Figure A.2. In this case these data points were eliminated yielding to loosing certain representation of these sectors in the analysis. Nevertheless, the data presented in this study remains the most comprehensive and publicly available information at this point.

\section{A.6 Statistical Model Development}

Linear regression was used to develop relationships between sales and electrical energy consumption of different manufacturing industries at the 4-Digit SIC. Correlations were examined between electrical energy consumption and square footage, number of employees, number of operating hours but gaps in the available datasets limited predictive power. Linear regression is an approach for modeling the relationship between a scalar dependent variable $y$ and one or more explanatory variables denoted $x$. The equation for this relationship is given as:

$$
y=\beta_{0}+\beta_{1} x+\varepsilon
$$

Where, $\beta_{1}$ represents the slope of the regression line (MWH/Sales), $\beta_{0}$ is the intercept and $\varepsilon$ the error associated with the observations. In many cases, the error between the data and linear relationship is minimized through the sum of the squared residuals or least squares. The regression coefficients are solved directly using the following equations: 
And

$$
\beta_{1}=\left(\sum x y-\left(\sum x \sum y / n 1\right)\right) /\left(\sum x^{2}-\left(\sum x\right)^{2} / n 1\right)
$$

$$
\beta_{0}=\left(\sum y / n 1-\beta_{1} \sum x / n 1\right)
$$

Where $\mathrm{n} 1$ represents number of data points. In some cases, outliers can exist and can cause the regression coefficients $\left(\beta_{1}\right.$ and $\left.\beta_{0}\right)$ to have misleading values. The coefficient of determination known as $R^{2}$ can be used to provide a measure of how well future outcomes are likely to be predicted by the model. $R^{2}$ values range between 0 and 1 , where 1 shows the best prediction capability. The $R^{2}$ value can be calculated as follows:

$$
R^{2}=1-\left(\sum\left(y_{i}-f_{i}\right)^{2}\right) /\left(\sum\left(y_{i}-\bar{y}\right)^{2}\right)
$$

Where, $f_{\mathrm{i}}$ represents the linear regression solution. The available information including sales and electrical energy consumption were obtained mainly from the IAC DB. This information was applied to the linear regression equation to derive relevant coefficient of regressions:

$$
E(S I C)=\beta S(S I C)+S_{0}(S I C)
$$

Where, $E$ represents electrical energy of a given industry type in MWh, $S$ is the product sales in a given industry type in dollars, and $S_{0}$ a constant determined by the regression analysis. Higher resulting values of $\beta$ indicate industries where electricity is important in the manufacturing of a given product. This will be explained in details in the results section of this paper. An example of the linear regression performed for the glass industry (SIC 3211) is shown in Figure A.5.

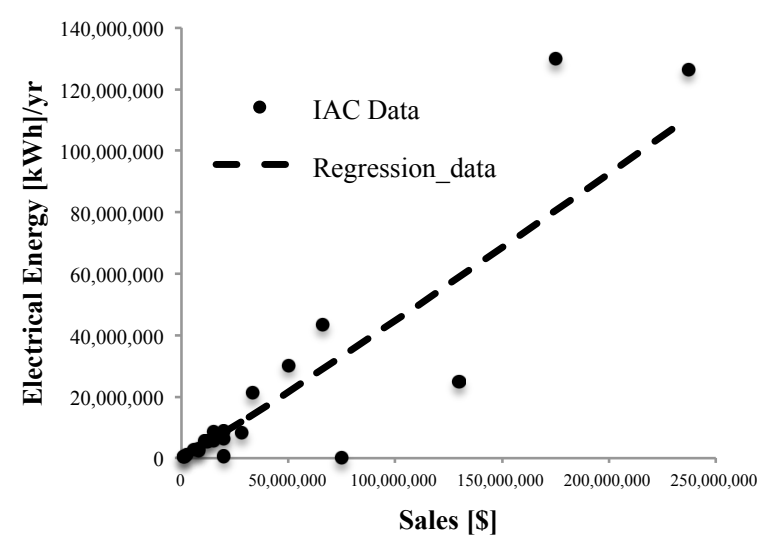

Figure A. 5 Regression Analysis on SIC 3211.

The derived coefficients of regression for each type of industry as represented by SIC code (captured from IAC DB) were applied to the corresponding SIC in the MNI database where the sales information of each manufacturing plant is utilized to predict the plant level electrical energy consumption associated with this given SIC across the U.S. industrial sector.

\section{A.7 Electricity Intensity (ELI)}

The statistical model developed resulted in a metric that we will be using from this point forward. This metric is the Electricity Intensity (ELI). ELI is defined as electrical energy use in $\mathrm{MWh}$ per product sales in dollar, $\mathrm{MWh} / \mathbf{\$}$. Product sales represent the value added to a 
given manufacturing facility. The greater the value of the ELI the more important the electricity as an energy stream to a given industrial sector.

\section{A.8 User Interface}

The IGATE-E@ was developed in a MATLAB platform and provides user-friendly interfaces to examine the various results of the statistical models. The current version of the tool consists of two main modules; electrical energy analysis module and geospatial linking module. The details of one of the computational modules are shown in Figure A.6. The Geospatial button enables the user to geospatially plot individual industries across the U.S. at zip code level and predicted electrical energy consumption

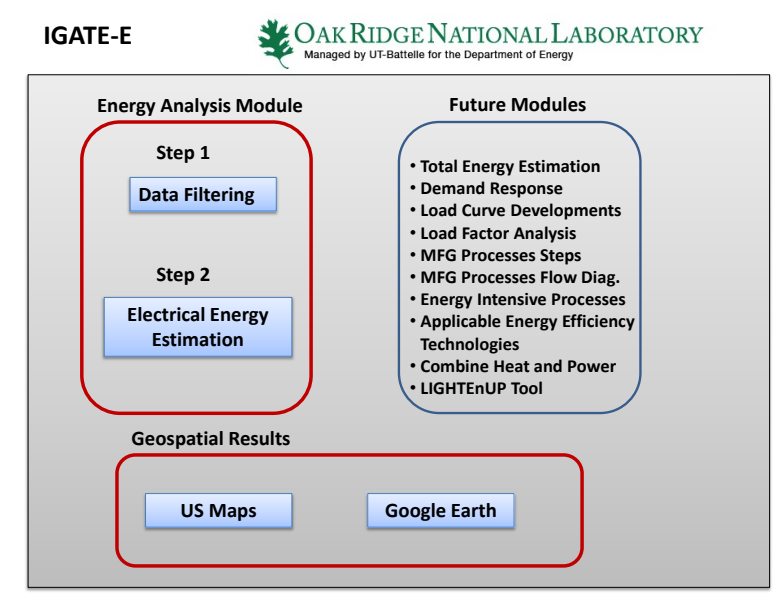

Figure A. 6 IGATE-E@ Main User Interface

The regression engine interface is shown in Figure A.7. The stars represent actual data points of data stream D1 (IAC datasets), triangles represent the outliers, and the line represents the regression model for this data. Industries at both 2-digit SIC and 4-digit SIC are selectable for regression analysis.

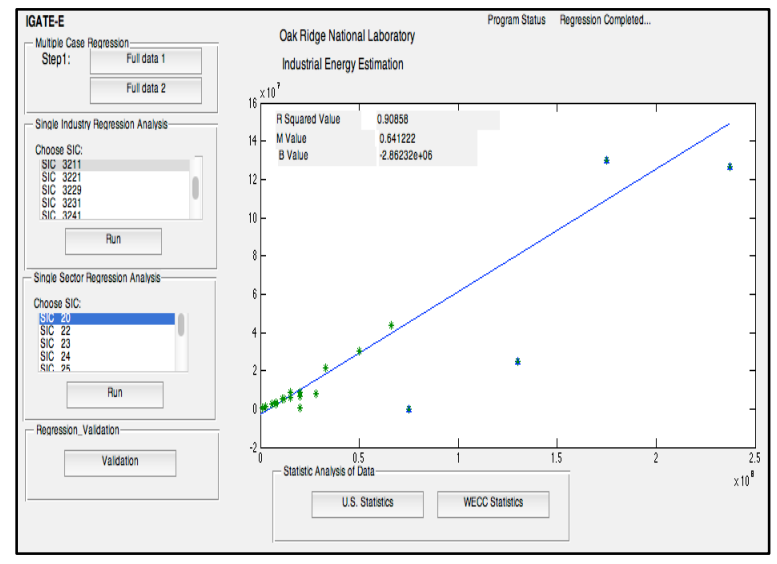

Figure A. 7 Regression Engine Interface

Selecting 'Validation' provides the comparison against the statistics of industrial electricity consumption provided by the EIA-MECS DB. Selecting 'U.S. Statistics' undertake a deeper examination of the information across the U.S. including industry count by state and estimated electrical energy consumption by sector for each state. 


\section{Analysis of Preliminary Results}

Current version of the tool provides multi-layer industrial energy information at different levels of granularity including; manufacturing plant level, zip code level, county level, regional level, state level, and national level. In the following, we will present few examples and a case study.

\section{LAYER 1 - INDUSTRIAL ENERGY INFORMATION BY MAJOR INDUSTRY GROUP (2-DIGIT SIC)}

The industrial sector is highly heterogeneous, with nine major industry groups (also referred to as sectors) representing over 400 types of manufacturing industries within the four-digit SIC system. To determine major industry groups where electricity is significant in the manufacturing of products, the 2-digit SIC major industrial groups were first examined

Figure A.8 shows the electricity intensity (ELI) in kWh per product sales in dollars for the 9 major industry groups and the electricity consumption as a function of product sales respectively.

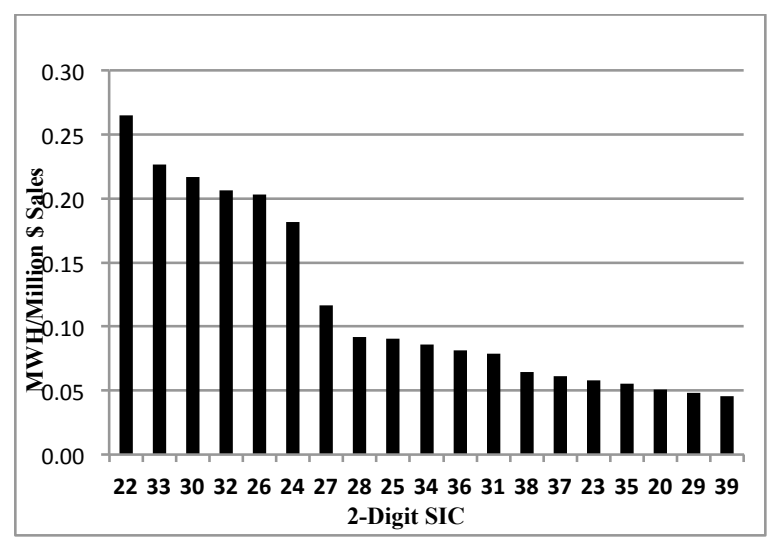

Figure A. 8 IGATE-E@ Model Results for All Manufacturing Sectors (SIC 20-39) Electricity Intensity (ELI)

The highest electricity intensities within these major industry groups are also represented by the highest bars as shown in Figure A.8 and highest slopes as shown in Figure A.9, below. The top three electricity intensive industrial sectors were Textile Mill Products (SIC 22), Primary Metal Industries (SIC 33) and Rubber and Miscellaneous Plastics Products (SIC 30). In Textile industry, electricity is a common power source for machinery such as winding/spinning, weaving, water pumps, dryers, cooling and temperature control systems. Primary metal industry (iron, steel, and non-ferrous metals) is in top three because of the intensive use of electric arc furnaces, induction furnaces, electrolysis, etc. Rubber and Plastic, mixing, extruders, and mills are electricity intensive equipment in tire manufacturing. Mixing, laminating, injection molding, blow molding, extrusion molding, all these operations consume significant amounts of electricity. 


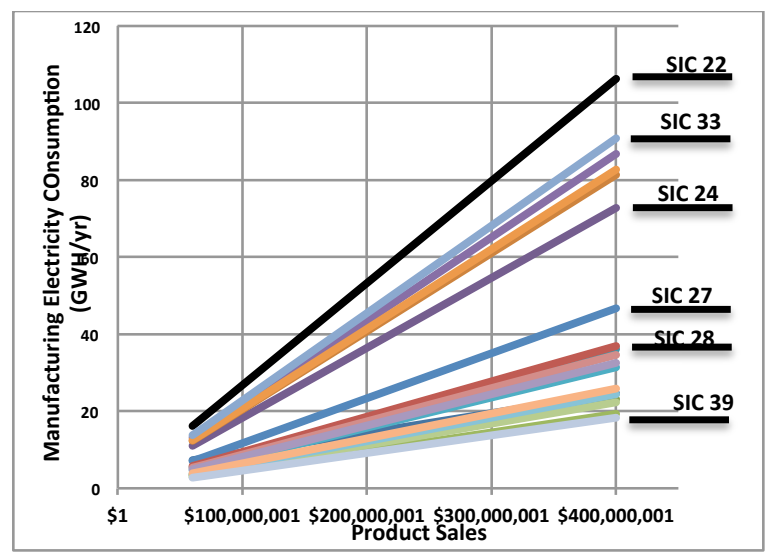

Figure A. 9 Electricity Consumption versus product sales in Dollar

Interestingly enough, known electricity intensive industries such as Computer and Electronics (SIC 36) didn't make it for the above top list. The reason is that the focus in this analysis is on the combined effect of electricity consumption and product sales. It appears that in the case of textile, the product sales value are not as significant compared to Computer and Electronics product sales value. This can also give an idea on the importance of electricity to industries like Textile, Primary Metals, and Rubber. The above chart suggests that a slight change in sales can have a major impact on ELI.

\section{LAYER 2 - INDUSTRIAL ENERGY INFORMATION BY SPECIFIC INDUSTRY (4-DIGIT SIC)}

Layer 1 of the analysis provided good information on the major industry sectors where the combined effect of electricity and product sales is significant. However, the energy analyst may need to get more information on specific type of industries within these sectors to perform more detailed analysis at the process level within each of these industries. Layer 2 of the analysis returns this important information. Figure 10 suggests that the top 3 electricity intensive industries in the Textile Sector are SIC 2284; Thread Mills, SIC 2210; Broad woven Fabric Mills, Cotton, and SIC 2298; Cordage and Twine (hemp rope made in spinning mills).

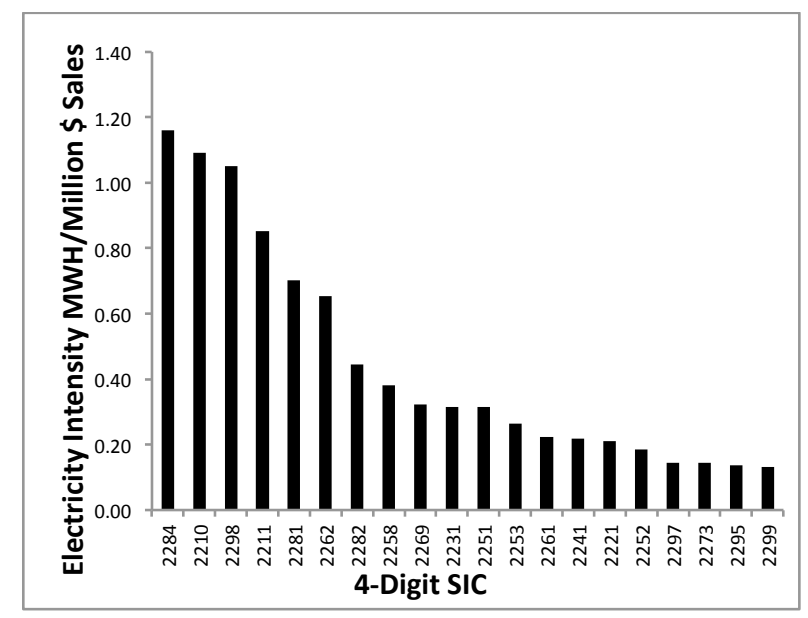

Figure A. 10 SIC 2210-2299 (All Textile Mill Industries) Electrical Energy Intensity. 
This analysis is important in spotting industries that are more likely to play a role in energy efficiency measures and demand response programs as reducing the cost of electricity plays a significant role in profits. This also provides plant managers the ability to gauge their plants performance within their SIC bracket. Figure A.11 shows representative sample of textile industries, due to limited space in this chart, we didn't include the full textile industries.

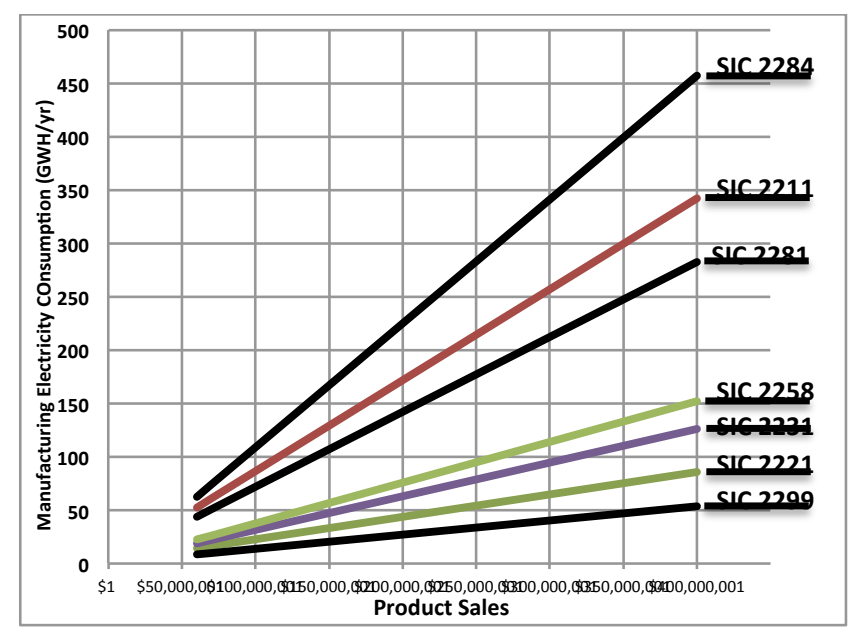

Figure A. 11 SIC 2210-2299 (Sample Textile Mill Industries) Electrical Energy Consumption as a Function of Products Sales.

The slope in this chart represents the electricity intensity in MWH per product sales. Steep slopes reflect electricity intensive industries in a given sector.

\section{A.9 Case Study}

Let's examine IGATE-E using a case study where the modeled industrial electrical energy consumptions at the state level were compared to those published by DOE's EIA-MECS. Then, we will examine the graphical interface of the tool by demonstrating the geospatial linking of some manufacturing plants (represented by SICs) using appropriate Zip code to GPS coordinates at each manufacturing plant's location in the US.

\section{a. Validation against DOE's EIA-MECS Published Data}

IGATE-E statistical module was used to apply data from IAC DB to the population of manufacturing plants $(300,000+)$ in the MNI DB and compared with the industrial electricity consumption state level data from the DOE's EIA-MECS as shown in Figure A.12. 


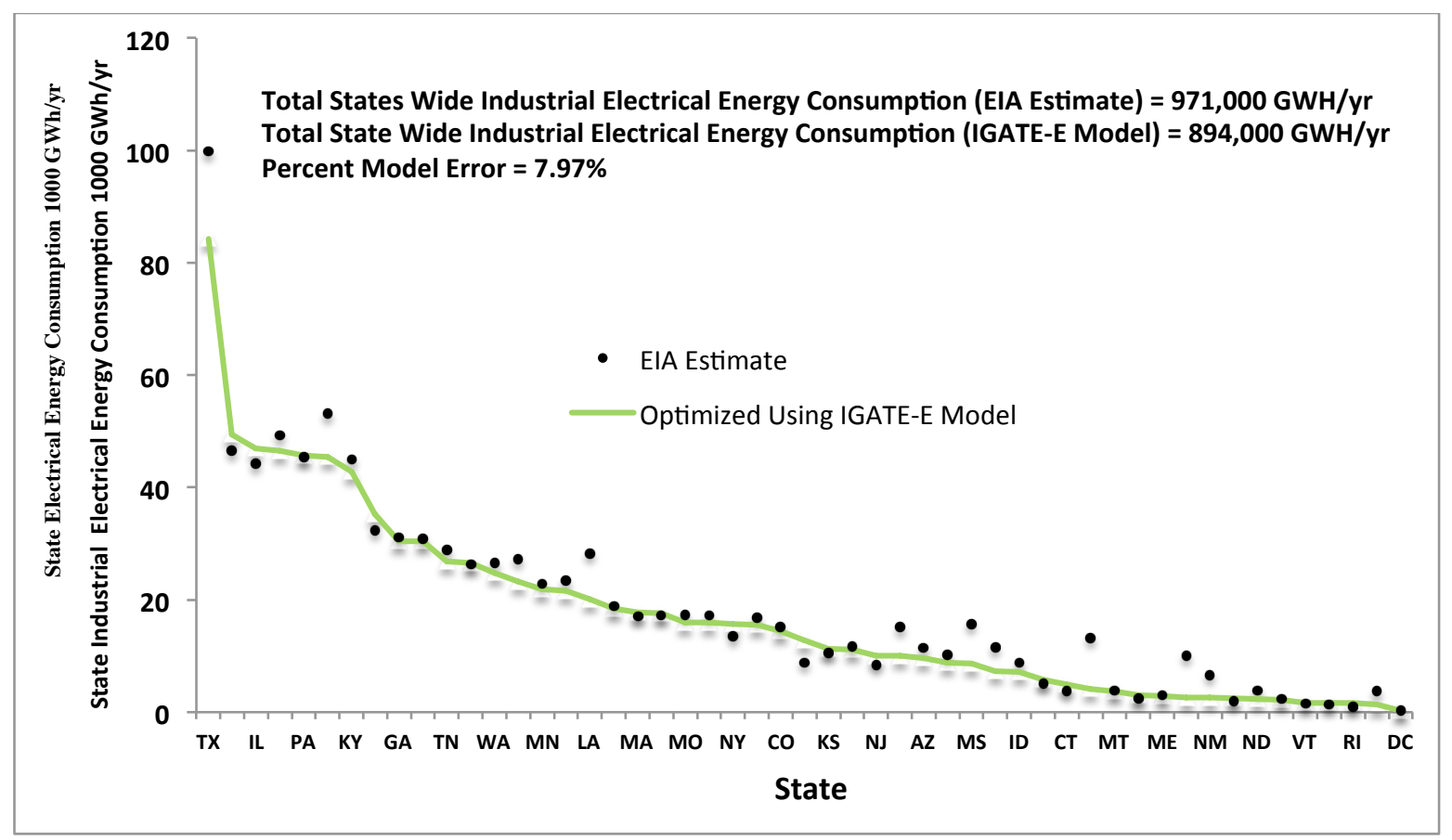

Figure A. 12 Comparison of Modeled Electrical Energy Versus EIA-MECS 2011 Published Data (Bottom up Approach).

This chart includes all 50 states, but there is limited space for labeling. As can be seen, the fitted data from the statistical module in most of the cases correlates well with the EIAMECS published data for the 50 states. Likely, the deviations will tighten up as more information becomes available for the IGATE-E model. It should be mentioned that the IAC$\mathrm{DB}$, one of the main data sources for this study is updated on a frequent basis. This will definitely improve the quality of regressions and curve fit for some industrial sectors and the overall validation process.

\section{b. Geospatial Linkage}

The mailing addresses for the plants provide zip codes which are directly linked to the plant's geospatial coordinates. When linked to the manufacturing plant level energy information each plant was mapped and relevant information were displayed to US Map or Google earth as shown in Figures A.13 and A.14. 


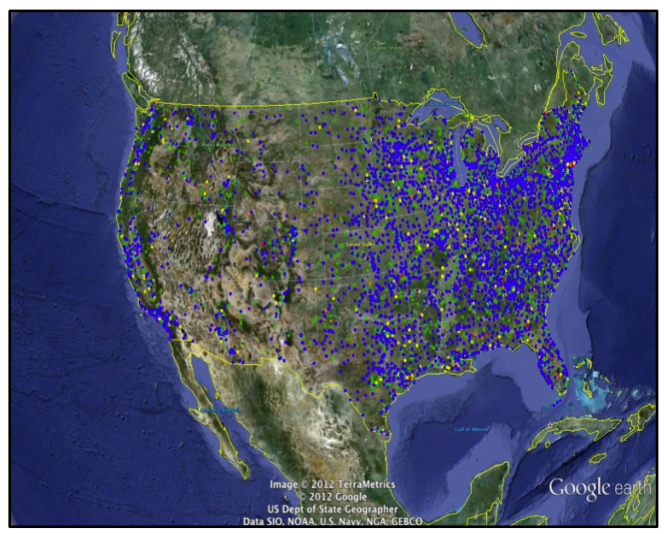

Figure A. 13 Geospatial Representation of Some Industries in Google Earth.

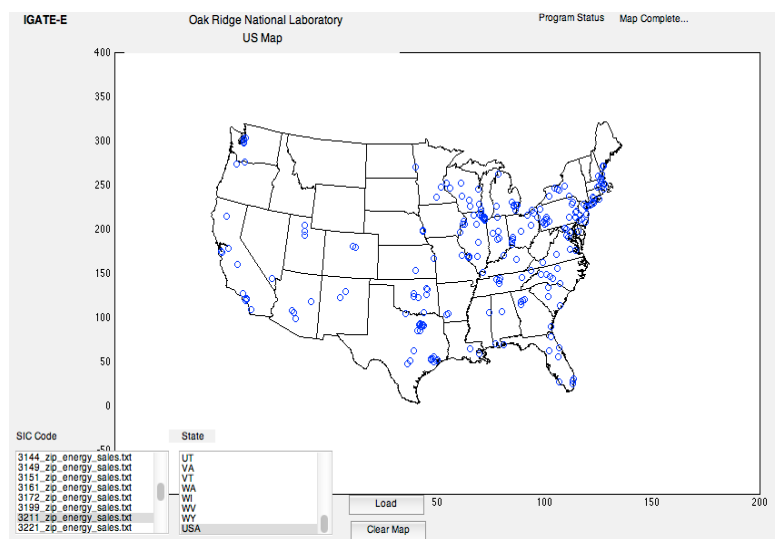

Figure A. 14 Geospatial Representation of Flat Glass Plants (SIC 3211) in US Map using MATLAB Mapping Function.

\section{A.10 Conclusion}

We developed a framework "IGATE-E" tool to utilize the available wealth of information in the publicly available datasets to provide a reasonable estimate of manufacturing electrical energy consumption at multiple levels of details and with minimal input information. The data input to the tool can be as little as a zip code or an SIC code of an industrial plant but the data output is numerous and can include information such as electric energy intensity $(\mathrm{MWH} / \$)$ per industry type and per zip code at the state and nationwide levels. Future versions of the tool will augment several modules such as manufacturing processes steps, energy intensive processes, applicable energy efficiency technologies, combine heat and power, to provide detailed analysis on indices of interest such as CHP capabilities across manufacturing sector, available low grade waste heat per industry type and per Region. All this info is provided at the geo-spatial resolution.

\section{REFERENCES}

1. William R. Morrow, etl. Cross-Sector Impact Analysis of Industrial Process and Materials, ACEEE 2013.

2. US. Energy Information Administration (EIA) [Online]. http://www.eia.gov/consumption/manufacturing/

3. Industrial Assessment Center Database. [Online] http://iac.rutgers.edu/database/ 
4. US Census Bureau. 2007 Economic Census, "Manufacturing: Industry Series: Detailed Statistics by Industry for the United States." EC0731/1. [Online] http://factfinder2.census.gov/faces/tableservices/jsf/pages/productview.xhtml

5. Manufacturing News, Inc Database [Online]. http://www.mnistore.com/

6. Evans, James, R., Statistics, Data Analysis \& Decision Modeling (4th Edition), 2010

7. B. Gopalakrishnan, R.W. Plummer, Alkadi, N., Analysis of Energy Conservation Opportunities in Glass Manufacturing Facilities, Journal of the Association of Energy Engineering, Vol. 98, No. 6, pp. 27-49, 2001.

8. B. Gopalakrishnan, R.W. Plummer, Alkadi, N., Comparison of Glass Manufacturing Facilities Based On Energy Consumption And Plant Characteristics, The Journal of Energy and development, Volume number (27), 2002

9. Ookie Ma, etl., Demand Response for Ancillary Services, IEEE Transactions on Smart Grid, TSG- 00707-2012.R1, in the press. 


\section{APPENDIX B Load Curve Development}

\section{B.1 Genetic Algorithms (GA) Method to Create the LOAD Curve}

Genetic algorithm is a heuristic set of processes that represent natural selection or evolution. This algorithm is often utilized to solve optimization problems and involves the presentation of populations, combinations of parents, and creations of new populations through mutations and crossovers as shown in Figure B.1 As the populations continue to be created, the more optimum solution is stored and used as the next generation, while the worst solution is thrown out. In this case, the genetic algorithm is used to create the most optimum load curve based on the load factor calculated.

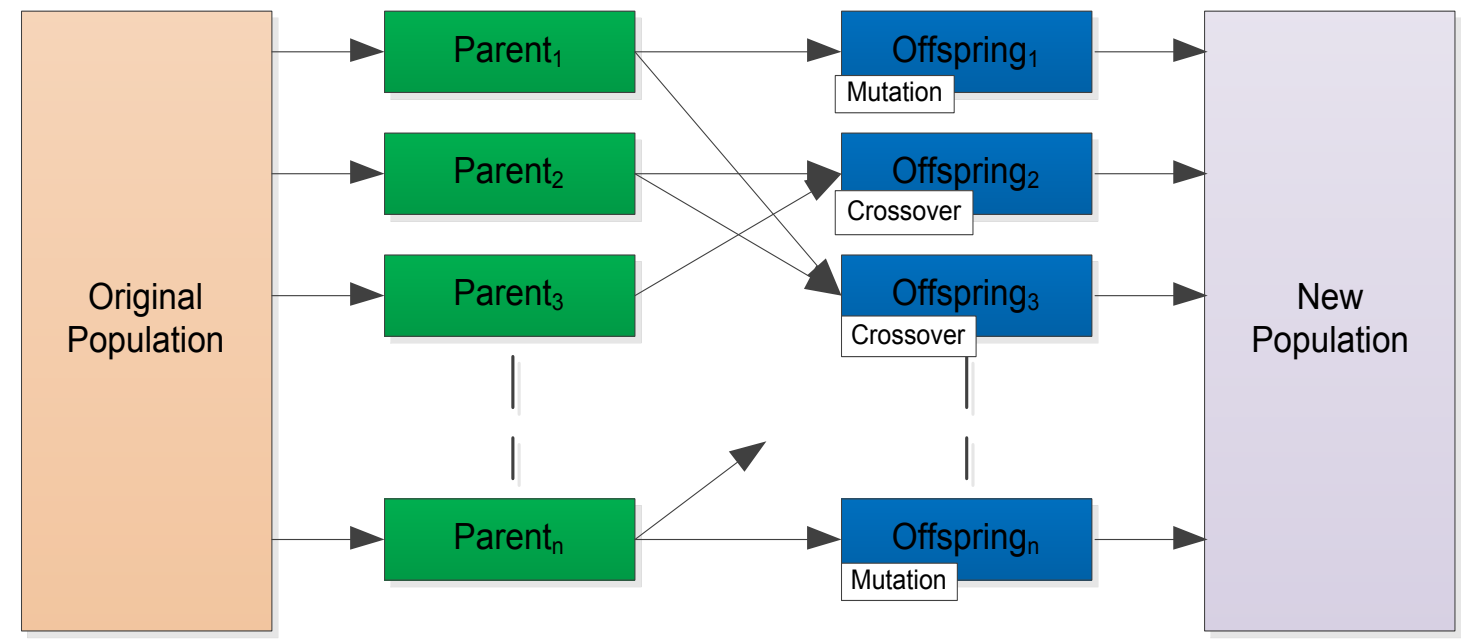

Figure B. 1 Genetic Algorithm (GA) Description.

Between the hours of 9AM and 4PM the load is set to a maximum of 1PU and the other hours are set to be optimized based on obtaining the needed load factor and constraining to a third order poly fit curve. The weekend is set to be the minimum of the weekday curve. This methodology distinctly captures various overall plant operations, but assumes that no energy management strategies are under implementation (i.e. the load curve is not shifted to non-peak hours.) This methodology also assumes that there is no change in load profile in relation to temperature, season, or holiday. An example load curve is provided in Figure B.2. 


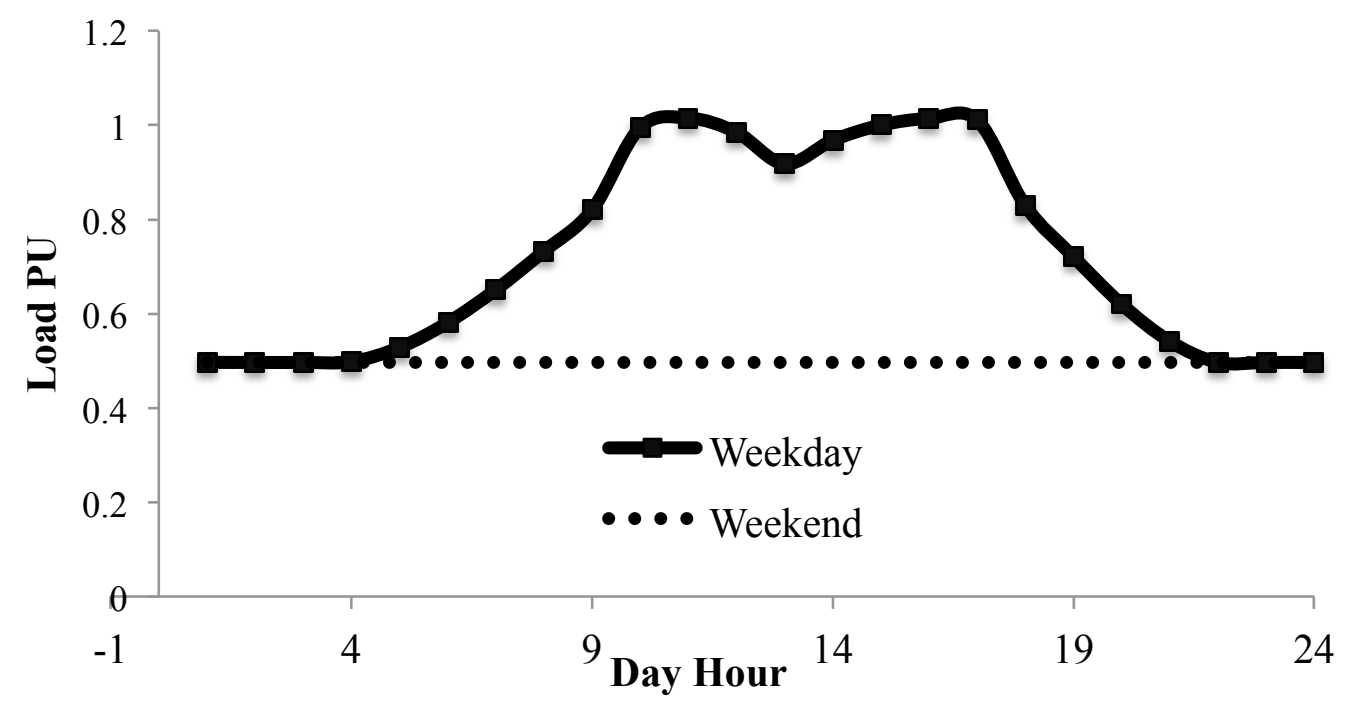

Figure B. 2 PU load curve for SIC 32 by GA

This methodology is expected to capture industries that have a fairly flat profile and those that see significant 24 -hour changes. As an example, a relatively flat overall plant will provide a high load factor or approximately one. As a result, the load curve will be optimized to have very minimal 24 hour load variations with high weekend consumption. Likewise, a low load factor will result in significant 24 hour changes. Several example industry results are shown in Figure B.3.

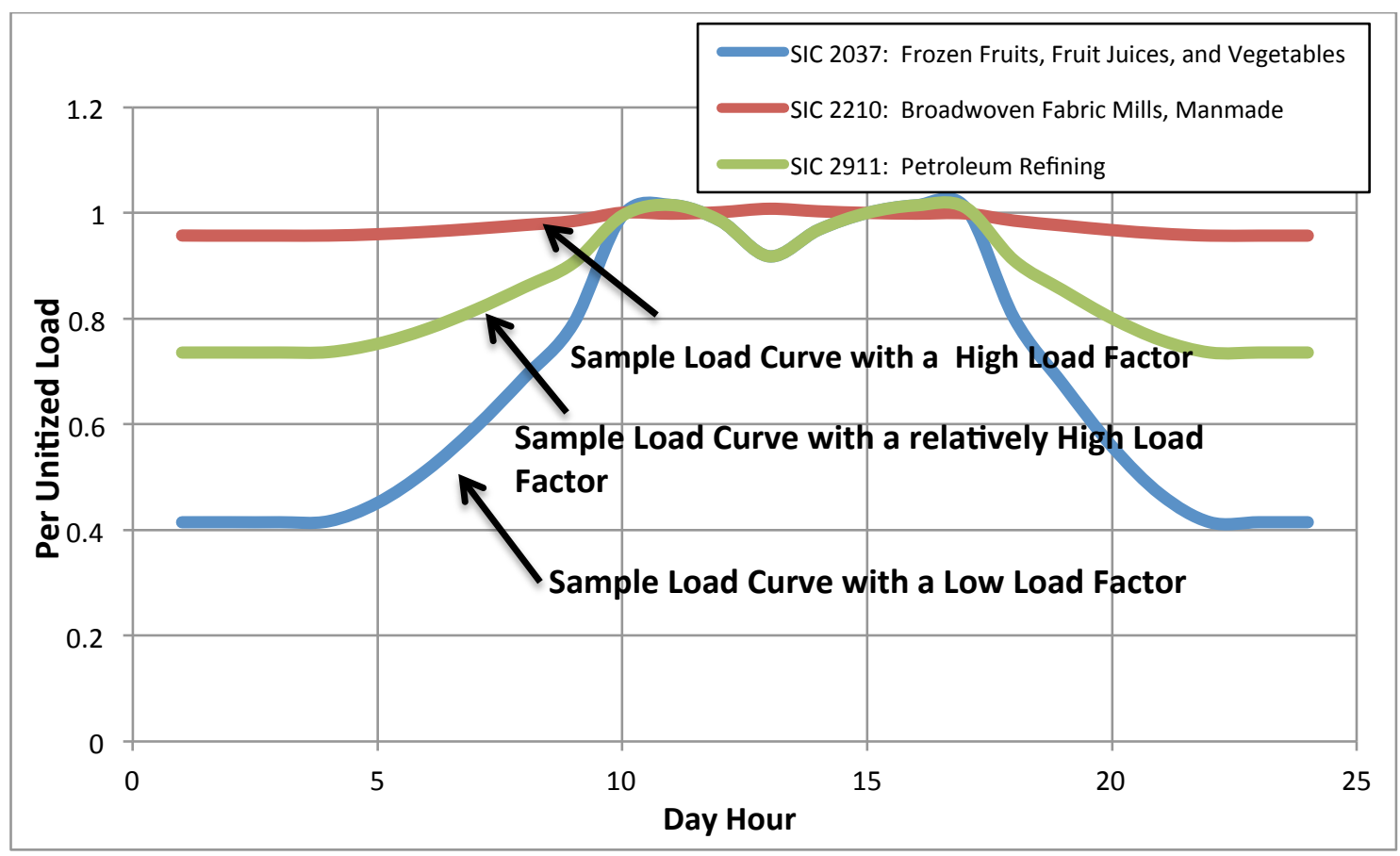

Figure B. 3 Load curves for high load factor and low load factor. 


\section{B.2 Scaling Per Unitized Load Curve}

The developed PU load curve were scaled based on the calculated plant energy and the results of the regression analysis involving peak (kW) and electrical energy (kWh). This regression analysis was also performed at the 4 digit SIC level.

\section{B.3 Breakdown of Load Curve Based on Process Steps}

In breaking the load curves into the corresponding industrial processes, each industrial process was broken down into process steps. Each process step is a part of the facility's requirement to do some form of useful work. Multiple process steps are expected in each industry with specific devices functioning in tandem to create a product. Devices are defined as the terminal unit of the process step that consumes the electrical energy. Often, a process step comprises of a collection of devices. Each device has a list of set of constraints that contribute to its overall ability to participate in demand-side load management. This breakout provides indication on the energy intensive processes and the respective energy percentages to the whole process. For examining industrial sectors by a two digit representation, the larger and more common processes were extracted.

An example curve of a plant with a foundry is shown in Figure B.4. An hourly profile as well as 5 minute data is shown to provide prospective of actual plant operations versus the hourly profiles created for this study. Examination of the load factor provides a window into the possibility of the schedule of these load types by plant.

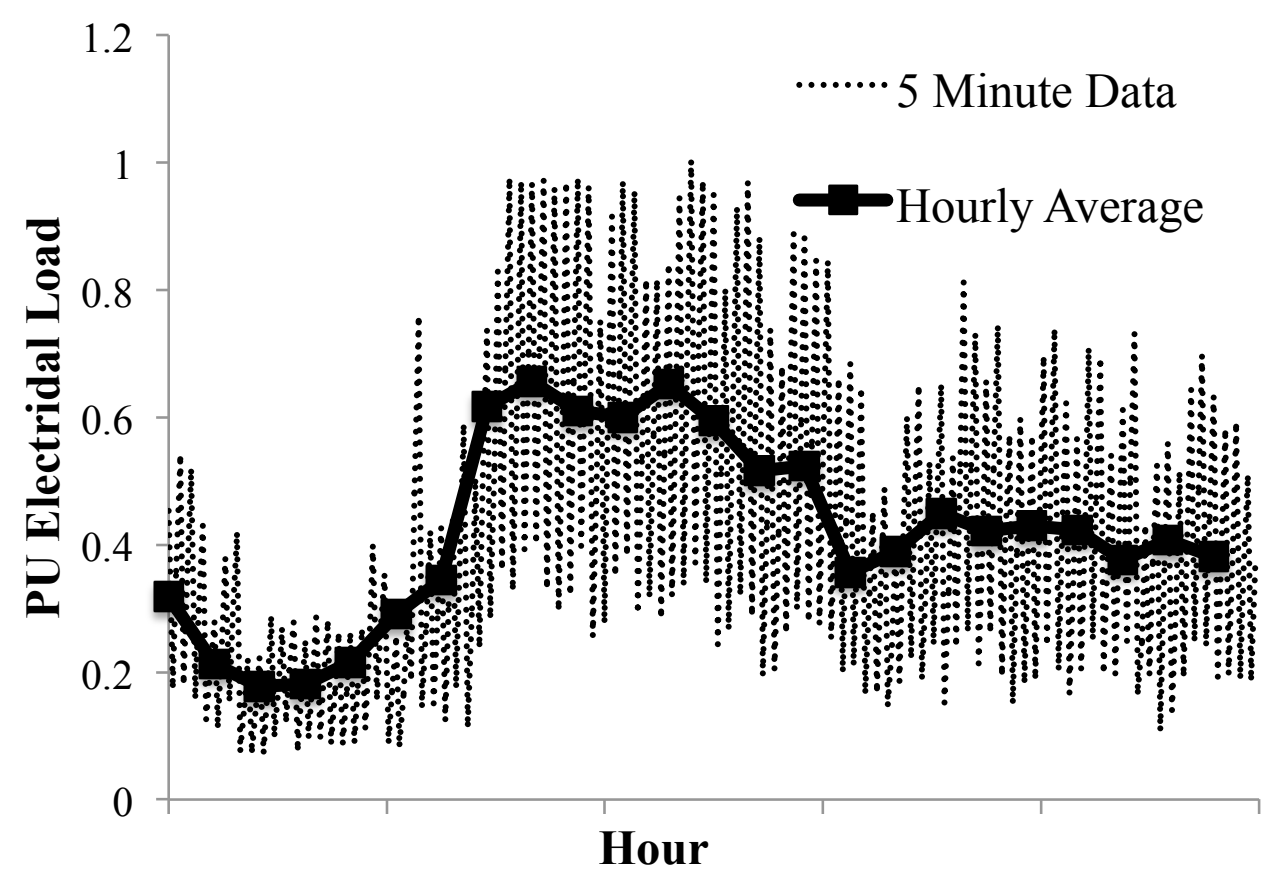

Figure B. 4. Example Daily Load Curve for an Iron Foundry.

FLAT GLASS EXAMPLE (SIC 3211) 
The glass manufacturing process, as an example demonstration, is broken down into the various process steps as shown Figure 2.7. Manufacturing process steps include: mixing, melting, refining, fabrication, annealing, finishing, crushing, tempering, lamination, autoclaving, cooling, and packaging. The use of electricity in these stages is highlighted to identify potential DR opportunities and load curve development. Each process step is then examined for the type of characteristic devices and loads and classified as either Mechanical I (cutting, pressing, mixing) that is typically not flexible and or Mechanical II (pumping, moving, transporting, fans) that is typically able to provide flexibility for DR), and Thermal (Heating, melting, evaporation) which represent systems comprised of thermal inertia and are typically flexible enough for DR.

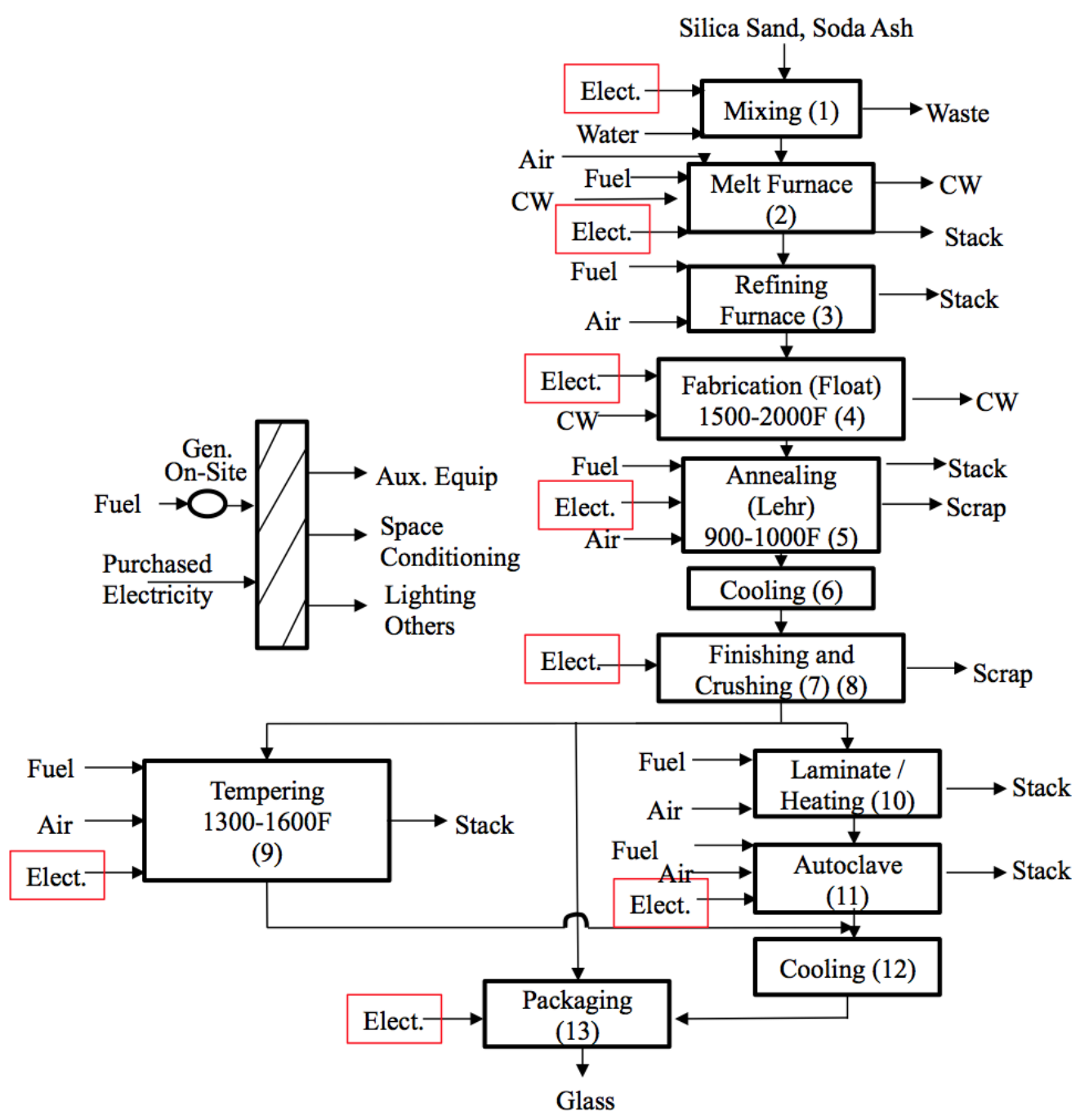

Figure B. 5 Process Flow diagram for SIC 3211 (Flat Glass) 
Table B. 1 Process Steps Involved in Flat Glass Manufacturing Industry (SIC 3211)

\begin{tabular}{llll}
\hline \hline Step & Flat Glass & $\begin{array}{l}\text { \%Total } \\
\text { Electricity }\end{array}$ & Load Characterization \\
\hline 1 & Mixing & 6.76 & Mechanical I \\
2 & Furnace & 21.27 & Thermal \\
3 & Refining & 0.00 & NA \\
4 & Fabrication Float & 55.91 & Mechanical II \\
5 & Annealing & 1.68 & Mechanical II \\
6 & Cockling & 0.00 & NA \\
7 & Finishing & 0.85 & Mechanical II \\
8 & Crushing & 0.85 & Mechanical I \\
9 & Final Heat Treatment & 7.99 & Thermal \\
10 & Heating & 0.00 & NA \\
11 & Autoclave & 2.98 & Thermal \\
12 & Cooling & 0.00 & NA \\
13 & Packaging & 1.70 & Mechanical I \\
14 & Electric Generation & 0.00 & NA \\
\hline \hline
\end{tabular}

\section{B.4 Graphical Representation of Manufacturing Plants}

The mailing addresses for the plants affiliated to different SICs provide zip codes which are directly linked to the plant's geospatial coordinates. When linked to the manufacturing plant level energy information each plant was mapped and relevant information was displayed to US Map or Google earth. Figures B.6 and B.7 show sample plant locations for four different industrial sectors SIC 20, SIC 22, SIC 30, and SIC 32 as an example.

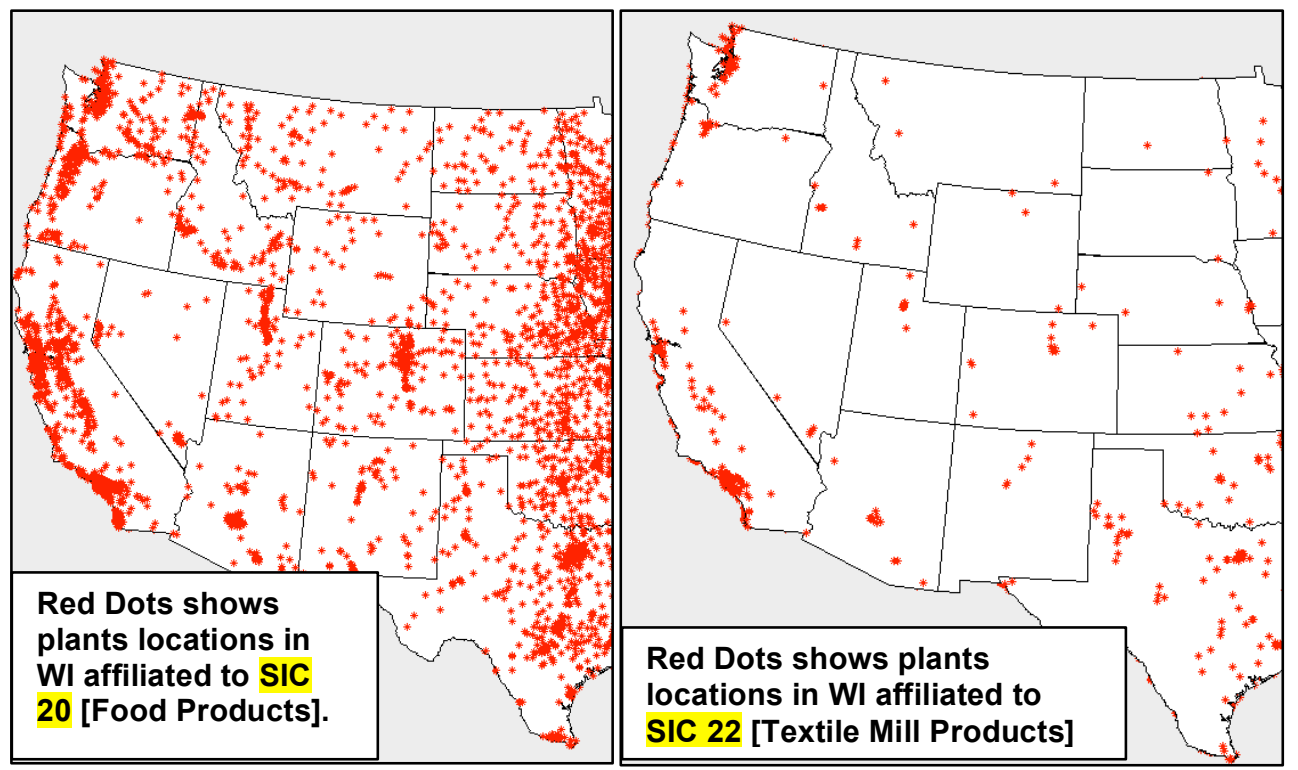

Figure B. 6 Graphical Representation for SIC 20 and SIC 22 


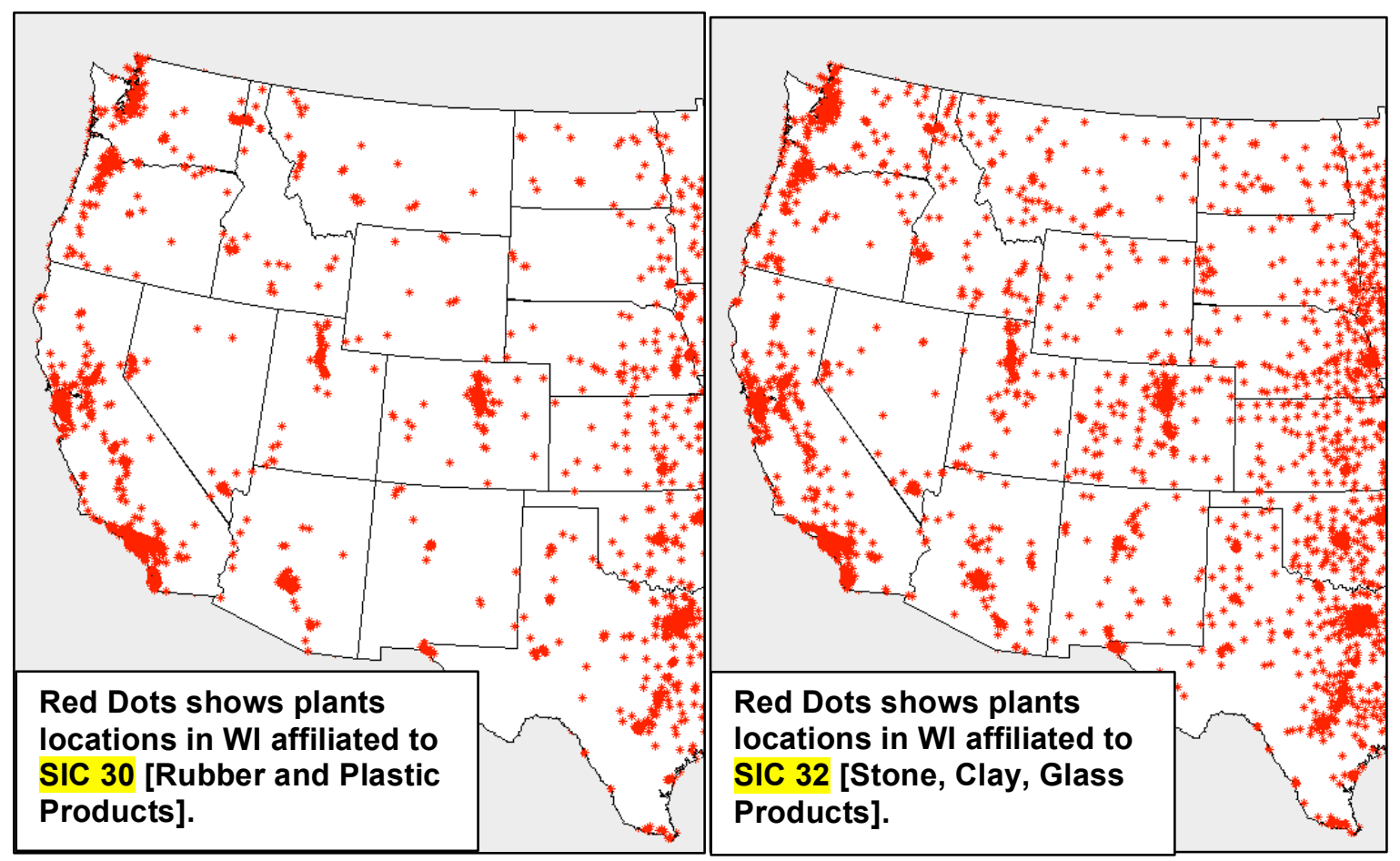

Figure B. 7 Graphical Representation for SIC 30 and SIC 32 


\section{APPENDIX C Demand Response Potential in Industrial Sector}

\section{Table C. 1 Dominating Process \& Load Characterization for the top selected industrial sectors (20-27)}

\begin{tabular}{|c|c|c|c|c|}
\hline SIC & Description (A) & $\begin{array}{c}\text { Dominating } \\
\text { Processes }\end{array}$ & Process \& Load Characterization & $\underset{*}{\% \text { Electricity }}$ \\
\hline 20 & $\begin{array}{l}\text { Food And } \\
\text { Kindred Products }\end{array}$ & Packaging & $\begin{array}{l}\text { Packaging Film Cutting - Rotating Conveyor - Packaging Sealing } \\
\text { and Pressing - The prevalent nature of this process is a non- } \\
\text { modulation. However, these loads can be turned on/off given } \\
\text { that the allowable starts and starting intervals are followed }\end{array}$ & 20 \\
\hline 20 & $\begin{array}{l}\text { Food And } \\
\text { Kindred Products }\end{array}$ & Chiller & $\begin{array}{l}\text { Water Pumping (VFD is a Possibility) - Refrigeration } \\
\text { Compressor (VFD) - Cooling Fans (VFD) - Thermal Inertia - } \\
\text { Proper Programming of operations can enable load shifting - } \\
\text { Well insulated Refrigeration Warehouses can enable all } 5 \text { DR } \\
\text { products }\end{array}$ & 34 \\
\hline 22 & $\begin{array}{l}\text { Textile Mill } \\
\text { Products }\end{array}$ & Wrapping & $\begin{array}{l}\text { Electric Motor to Roll textile products - Usually Rotating Motion, } \\
\text { speed is controlled based on the size of textile, although, speed } \\
\text { can be controlled, but likely for process purposes only - Load } \\
\text { can be classified as ON/OFF }\end{array}$ & 21 \\
\hline 22 & $\begin{array}{l}\text { Textile Mill } \\
\text { Products }\end{array}$ & Weaving & $\begin{array}{l}\text { weaving is a process of interlacing two types of yarn run parallel } \\
\text { to the weaving machine known as loom and weft or filling yarn } \\
\text { (run perpendicular to the loom) to produce a rigid fabric. } \\
\text { Processes in weaving are shedding, picking and beating } \\
\text { process, all sensitive to rotational speed and will not be good } \\
\text { candidate for regulations. - Load can be classified as ON/OFF }\end{array}$ & 25 \\
\hline $23^{* *}$ & $\begin{array}{l}\text { Apparel and } \\
\text { other Textile Mill } \\
\text { Products }\end{array}$ & $\begin{array}{l}\text { Wrapping (Assumed } \\
\text { Similar to dominating } \\
\text { process in SIC 22) }\end{array}$ & See above & 21 \\
\hline $23^{* *}$ & $\begin{array}{l}\text { Apparel and } \\
\text { other Textile Mill } \\
\text { Products }\end{array}$ & $\begin{array}{l}\text { Weaving (Assumed } \\
\text { Similar to dominating } \\
\text { process in SIC 22) }\end{array}$ & See above & 25 \\
\hline 24 & $\begin{array}{l}\text { Lumber And } \\
\text { Wood Products, } \\
\text { Except Furniture }\end{array}$ & Sawing & $\begin{array}{l}\text { Mainly Cutting Process - Involves Electric Motor and Saw blades } \\
\text { to cut wood - Do not offer Modulation - But can be turned } \\
\text { ON/OF, making it candidate for Energy, Capacity. }\end{array}$ & 22 \\
\hline 24 & $\begin{array}{l}\text { Lumber And } \\
\text { Wood Products, } \\
\text { Except Furniture }\end{array}$ & Planning & $\begin{array}{l}\text { Finishing Process that involves excretion of force on a piece of } \\
\text { wood to make smooth and take finishing form. Same as Sawing } \\
\text { in terms of DR products }\end{array}$ & 22 \\
\hline $25^{\star *}$ & $\begin{array}{l}\text { Furniture and } \\
\text { Fixtures }\end{array}$ & $\begin{array}{l}\text { Sawing [Assumed } \\
\text { Similar to dominating } \\
\text { process in SIC 24] }\end{array}$ & See above & 22 \\
\hline $25^{\star *}$ & $\begin{array}{l}\text { Furniture and } \\
\text { Fixtures }\end{array}$ & $\begin{array}{l}\text { Planning [Assumed } \\
\text { Similar to dominating } \\
\text { process in SIC 24] }\end{array}$ & See above & 22 \\
\hline 26 & $\begin{array}{l}\text { Paper And Allied } \\
\text { Products }\end{array}$ & Chipper & See Ball Mill Explanation Below & 6 \\
\hline 26 & $\begin{array}{l}\text { Paper And Allied } \\
\text { Products }\end{array}$ & Dewatering Press & $\begin{array}{l}\text { Pressing - Electric loads consist of fans/pumps/motors used for } \\
\text { hydraulic press control. Does have process storage and would } \\
\text { be a good candidate for Load Shifting and Firm Capacity }\end{array}$ & 26 \\
\hline $27^{* *}$ & $\begin{array}{l}\text { Printing and } \\
\text { Publishing }\end{array}$ & $\begin{array}{l}\text { Compressor [Assumed } \\
\text { Similar to dominating } \\
\text { process in SIC 28] }\end{array}$ & See below & 7 \\
\hline $27^{* *}$ & $\begin{array}{l}\text { Printing and } \\
\text { Publishing }\end{array}$ & $\begin{array}{l}\text { Grinding [Assumed } \\
\text { Similar to dominating } \\
\text { process in SIC 28] }\end{array}$ & See below & 36 \\
\hline \multicolumn{5}{|c|}{ *(PS/Total Electricity in SIC) ${ }^{* *}$ Due to insufficient information, closest possible Sector to this sector was selected } \\
\hline
\end{tabular}


Table C. 2 Dominating Process \& Load Characterization for the top selected industrial sectors (28-33)

\begin{tabular}{|c|c|c|c|c|}
\hline SIC & $\begin{array}{l}\text { Description } \\
\text { (A) }\end{array}$ & $\begin{array}{l}\text { Dominating } \\
\text { Processes }\end{array}$ & Process \& Load Characterization & $\begin{array}{c}\% \\
\underset{*}{\text { Electricity }}\end{array}$ \\
\hline 28 & $\begin{array}{l}\text { Chemicals } \\
\text { And Allied } \\
\text { Products }\end{array}$ & Electrolysis & $\begin{array}{l}\text { In chemical sector, it is generally estimated that electrolysis } \\
\text { cells account for about } 75-90 \% \text { of the total load of the facility. } \\
\text { When needed, the cells can operate at } 60 \% \text { of rated capacity, } \\
\text { making it good candidate for Regulation, specifically. }\end{array}$ & 43 \\
\hline 28 & $\begin{array}{l}\text { Chemicals } \\
\text { And Allied } \\
\text { Products }\end{array}$ & Compressor & $\begin{array}{l}\text { Usually equipped with VFD, allow modulation, can be good } \\
\text { candidate for Regulation. Usually, downstream of this } \\
\text { process there are tanks for the storage of the compressed } \\
\text { fluids and this allows the modulation of the compressors } \\
\text { according to the available storage capacity and the shipment } \\
\text { rate. }\end{array}$ & 7 \\
\hline 28 & $\begin{array}{l}\text { Chemicals } \\
\text { And Allied } \\
\text { Products }\end{array}$ & Grinding & See Ball Mill Explanation Below & 36 \\
\hline 29 & $\begin{array}{l}\text { Petroleum } \\
\text { Refining And } \\
\text { Related } \\
\text { Industries }\end{array}$ & Catalytic Cracking & $\begin{array}{l}\text { Mostly Pumping, Lots of Storage Tanks, Some Compressors, } \\
\text { VFD is numerous, can provide all } 5 \text { DR services with variable } \\
\text { amounts }\end{array}$ & 26 \\
\hline 30 & $\begin{array}{l}\text { Rubber And } \\
\text { Miscellaneou } \\
\text { s Plastics } \\
\text { Products }\end{array}$ & Mixing & See Ball Mill Explanation Below & 46 \\
\hline 30 & $\begin{array}{l}\text { Rubber And } \\
\text { Miscellaneou } \\
\text { s Plastics } \\
\text { Products }\end{array}$ & Mill & See Ball Mill Explanation Below & 8 \\
\hline $31^{* *}$ & $\begin{array}{l}\text { Leather and } \\
\text { Products }\end{array}$ & $\begin{array}{l}\text { Mixing [Assumed Similar } \\
\text { to dominating process in } \\
\text { SIC 30] }\end{array}$ & See above & 46 \\
\hline $31^{* *}$ & $\begin{array}{l}\text { Leather and } \\
\text { Products }\end{array}$ & $\begin{array}{l}\text { Mill [Assumed Similar to } \\
\text { dominating process in } \\
\text { SIC 30] }\end{array}$ & See above & 8 \\
\hline 32 & $\begin{array}{l}\text { Stone, Clay, } \\
\text { Glass, And } \\
\text { Concrete } \\
\text { Products }\end{array}$ & Electric Furnace & $\begin{array}{l}\text { When required, the temperature set-point of the molten } \\
\text { material in the furnace is maintained with low power } \\
\text { consumption, either by operating the furnace at minimum } \\
\text { load or by resorting to auxiliary resistors. In surface treatment } \\
\text { facilities, the duty cycles must be carefully studied in order to } \\
\text { schedule the operations so as to limit the number of furnaces } \\
\text { that are on at the same time. This can be viewed as Thermal } \\
\text { storage capability and allow for Regulation. }\end{array}$ & 17 \\
\hline 32 & $\begin{array}{l}\text { Stone, Clay, } \\
\text { Glass, And } \\
\text { Concrete } \\
\text { Products }\end{array}$ & Crushing & $\begin{array}{l}\text { Ball Mill is used to crush stone of large grain size into } \\
\text { particles or powder. This equipment mostly runs once a day. } \\
\text { Feeding and unloading makes up the remaining time. The } \\
\text { milling cycle of a ball mill consists of one hour of feeding, 13- } \\
16 \text { hours of milling and half an hour of unloading. The power } \\
\text { capacity of this equipment is approximately } 600 \mathrm{~kW}-1150 \mathrm{~kW} \text {. } \\
\text { Its running greatly influences daily load curve of glass/cement } \\
\text { manufacturing processes. Cannot Modulate but good for } \\
\text { OFF/ON operations given that the given that the allowable } \\
\text { starts and starting intervals are followed - Can be viewed as } \\
\text { Isolated or Single Process }\end{array}$ & 36 \\
\hline 33 & $\begin{array}{l}\text { Primary } \\
\text { Metal } \\
\text { Industries }\end{array}$ & Electrolysis & See Electrolysis Explanation Above & 23 \\
\hline 33 & $\begin{array}{l}\text { Primary } \\
\text { Metal } \\
\text { Industries }\end{array}$ & $\begin{array}{l}\text { Crushing and } \\
\text { Classifying }\end{array}$ & See Ball Mill Explanation Above & 7 \\
\hline
\end{tabular}


Table C. 3 Dominating Process \& Load Characterization for the top selected industrial sectors (SIC37)

\begin{tabular}{|c|c|c|c|c|}
\hline SIC & $\begin{array}{c}\text { Description } \\
\text { (A) }\end{array}$ & $\begin{array}{l}\text { Dominating } \\
\text { Processes }\end{array}$ & Process \& Load Characterization & $\underset{*}{\% \text { Electricity }}$ \\
\hline 37 & $\begin{array}{l}\text { Transportation } \\
\text { Equipment } \\
\text { Transportation } \\
\text { Equipment }\end{array}$ & $\begin{array}{l}\text { Final } \\
\text { Assembly } \\
\text { Metal Cutting }\end{array}$ & $\begin{array}{l}\text { Mainly cutting, trimming, moving, conveyor, pushing, ... Good } \\
\text { candidates for ON/OFF } \\
\text { Metal cutting - Cannot Modulate - Not good for Regulation - } \\
\text { Can shut-off for extended periods as a cut metal sheet are } \\
\text { made and sent to the next process step (pressing) (Typical } \\
\text { sizes } 200 \mathrm{~kW} \text { - 300kW). Pressing - Electric loads consist of } \\
\text { fans/pumps/motors used for hydraulic press control. Does } \\
\text { have process storage and would be a good candidate for Load } \\
\text { Shifting and Firm Capacity - classified as non-critical } \\
\text { production process step that can be called upon and provide } \\
\text { these } 2 \text { services given that they have adequate warning. DR } \\
\text { SERVICEs for Both are Energy Shifting + Capacity Reserve } \\
\quad \text { *(PS/Total Electricity in SIC) }\end{array}$ & $\begin{array}{l}26 \\
21\end{array}$ \\
\hline
\end{tabular}

Table C. 4 Acceptability Percentages

\begin{tabular}{|c|c|c|c|}
\hline SIC Sector & Process & $\begin{array}{c}2006 \\
\text { Acceptability } \\
\text { (\%) }\end{array}$ & $\begin{array}{c}\text { Technical } \\
\text { Feasible } \\
(\%)\end{array}$ \\
\hline 20 & Packaging & 18 & 100 \\
\hline 20 & Chiller & 18 & 100 \\
\hline 22 & Wrapping & 14 & 100 \\
\hline 22 & Weaving & 14 & 100 \\
\hline 23 & $\begin{array}{l}\text { No Process Details - Assume SIC } \\
22\end{array}$ & 12 & 100 \\
\hline 23 & $\begin{array}{l}\text { No Process Details - Assume SIC } \\
22\end{array}$ & 12 & 100 \\
\hline 24 & Sawing & 15 & 100 \\
\hline 24 & Planning & 15 & 100 \\
\hline 25 & $\begin{array}{l}\text { No Process Details - Assume SIC } \\
24\end{array}$ & 13 & 100 \\
\hline 25 & $\begin{array}{l}\text { No Process Details - Assume SIC } \\
24\end{array}$ & 13 & 100 \\
\hline 26 & Chipper & 35 & 100 \\
\hline 26 & Dewatering Press & 35 & 100 \\
\hline 27 & $\begin{array}{l}\text { No Process Details - Assume SIC } \\
28\end{array}$ & 20 & 100 \\
\hline 27 & $\begin{array}{l}\text { No Process Details - Assume SIC } \\
28\end{array}$ & 20 & 100 \\
\hline 28 & Electrolysis & 40 & 100 \\
\hline 28 & Compressor & 40 & 100 \\
\hline 28 & Grinding & 40 & 100 \\
\hline 29 & Catalytic Cracking & 40 & 100 \\
\hline 30 & Mixing & 23 & 100 \\
\hline 30 & Mill & 23 & 100 \\
\hline 31 & $\begin{array}{l}\text { No Process Details - Assume SIC } \\
30\end{array}$ & 10 & 100 \\
\hline 31 & $\begin{array}{l}\text { No Process Details - Assume SIC } \\
30\end{array}$ & 10 & 100 \\
\hline 32 & Electric Furnace & 20 & 100 \\
\hline 32 & Crushing & 20 & 100 \\
\hline 33 & Electrolysis & 27 & 100 \\
\hline 33 & Crushing and Classifying & 27 & 100 \\
\hline 37 & Metal Cutting & 18 & 100 \\
\hline 37 & Final Assembly & 18 & 100 \\
\hline
\end{tabular}


Table C. 5 Controllability Percentages

\begin{tabular}{|c|c|c|c|c|c|c|}
\hline SIC & Dominating Processes (B) & \%Regulation & \%Contingency & $\%$ Flex & \%Energy & \%Capacity \\
\hline 20 & Packaging & 0 & 100 & 100 & 100 & 100 \\
\hline 20 & Chiller & 100 & 100 & 100 & 100 & 100 \\
\hline 22 & Wrapping & 0 & 100 & 100 & 100 & 100 \\
\hline 22 & Weaving & 0 & 100 & 100 & 100 & 100 \\
\hline 23 & No Process Details - Assume SIC 22 & 0 & 100 & 100 & 100 & 100 \\
\hline 23 & No Process Details - Assume SIC 22 & 0 & 100 & 100 & 100 & 100 \\
\hline 24 & Sawing & 0 & 100 & 100 & 100 & 100 \\
\hline 24 & Planning & 0 & 100 & 100 & 100 & 100 \\
\hline 25 & No Process Details - Assume SIC 24 & 0 & 100 & 100 & 100 & 100 \\
\hline 25 & No Process Details - Assume SIC 24 & 0 & 100 & 100 & 100 & 100 \\
\hline 26 & Chipper & 0 & 100 & 100 & 100 & 100 \\
\hline 26 & Dewatering Press & 0 & 100 & 100 & 100 & 100 \\
\hline 27 & No Process Details - Assume SIC 28 & 0 & 100 & 100 & 100 & 100 \\
\hline 27 & No Process Details - Assume SIC 28 & 0 & 100 & 100 & 100 & 100 \\
\hline 28 & Electrolysis & 100 & 100 & 100 & 100 & 100 \\
\hline 28 & Compressor & 100 & 100 & 100 & 100 & 100 \\
\hline 28 & Grinding & 0 & 100 & 100 & 100 & 100 \\
\hline 29 & Catalytic Cracking & 0 & 100 & 100 & 100 & 100 \\
\hline 30 & Mixing & 0 & 100 & 100 & 100 & 100 \\
\hline 30 & Mill & 0 & 100 & 100 & 100 & 100 \\
\hline 31 & No Process Details - Assume SIC 30 & 0 & 100 & 100 & 100 & 100 \\
\hline 31 & No Process Details - Assume SIC 30 & 0 & 100 & 100 & 100 & 100 \\
\hline 32 & Electric Furnace & 100 & 100 & 100 & 100 & 100 \\
\hline 32 & Crushing & 0 & 100 & 100 & 100 & 100 \\
\hline 33 & Electrolysis & 100 & 100 & 100 & 100 & 100 \\
\hline 33 & Crushing and Classifying & 0 & 100 & 100 & 100 & 100 \\
\hline 37 & Metal Cutting & 0 & 100 & 100 & 100 & 100 \\
\hline 37 & Final Assembly & 0 & 100 & 100 & 100 & 100 \\
\hline
\end{tabular}

Table C. 6 Sheddability of the Manufacturing Process

\begin{tabular}{|c|c|c|c|c|c|c|}
\hline SIC & Dominating Processes (B) & \%Regulation & \%Contingency & \% Flex & \%Energy & \%Capacity \\
\hline 20 & Packaging & 0 & 0 & 0 & 50 & 0 \\
\hline 20 & Chiller & 50 & 100 & 50 & 25 & 0 \\
\hline 22 & Wrapping & 0 & 0 & 0 & 50 & 0 \\
\hline 22 & Weaving & 0 & 0 & 0 & 50 & 0 \\
\hline 23 & No Process Details - Assume SIC 22 & 0 & 0 & 0 & 50 & 0 \\
\hline 23 & No Process Details - Assume SIC 22 & 0 & 0 & 0 & 50 & 0 \\
\hline 24 & Sawing & 0 & 0 & 0 & 80 & 0 \\
\hline 24 & Planning & 0 & 0 & 0 & 80 & 0 \\
\hline 25 & No Process Details - Assume SIC 24 & 0 & 0 & 0 & 80 & 0 \\
\hline 25 & No Process Details - Assume SIC 24 & 0 & 0 & 0 & 80 & 0 \\
\hline 26 & Chipper & 25 & 100 & 50 & 100 & 0 \\
\hline 26 & Dewatering Press & 0 & 0 & 0 & 100 & 0 \\
\hline 27 & No Process Details - Assume SIC 28 & 25 & 100 & 50 & 100 & 0 \\
\hline 27 & No Process Details - Assume SIC 28 & 0 & 0 & 0 & 100 & 0 \\
\hline 28 & Electrolysis & 100 & 100 & 100 & 0 & 0 \\
\hline 28 & Compressor & 10 & 20 & 10 & 0 & 0 \\
\hline 28 & Grinding & 50 & 100 & 59 & 100 & 0 \\
\hline 29 & Catalytic Cracking & 25 & 50 & 25 & 25 & 0 \\
\hline 30 & Mixing & 50 & 100 & 50 & 100 & 0 \\
\hline 30 & Mill & 50 & 100 & 50 & 100 & 0 \\
\hline 31 & No Process Details - Assume SIC 30 & 50 & 100 & 50 & 100 & 0 \\
\hline 31 & No Process Details - Assume SIC 30 & 50 & 100 & 50 & 100 & 0 \\
\hline 32 & Electric Furnace & 30 & 100 & 100 & 60 & 0 \\
\hline 32 & Crushing & 50 & 100 & 100 & 100 & 0 \\
\hline 33 & Electrolysis & 100 & 100 & 100 & 0 & 0 \\
\hline 33 & Crushing and Classifying & 50 & 100 & 100 & 100 & 0 \\
\hline 37 & Metal Cutting & 0 & 10 & 10 & 80 & 0 \\
\hline 37 & Final Assembly & 0 & 0 & 0 & 20 & 0 \\
\hline
\end{tabular}


Table C. 7 Sheddability of the Device within the Manufacturing Process

\begin{tabular}{|c|c|c|c|c|c|c|}
\hline $\mathrm{SIC}$ & "Dominating Processes (B) & \%Regulation & \% \%Contingency & \% Flex & \%Energy & \%Capacity \\
\hline 20 & Packaging & 0 & 0 & 0 & 80 & 80 \\
\hline 20 & Chiller & 10 & 30 & 30 & 80 & 80 \\
\hline 22 & Wrapping & 0 & 0 & 0 & 80 & 80 \\
\hline 22 & Weaving & 0 & 0 & 0 & 80 & 80 \\
\hline 23 & No Process Details - Assume SIC 22 & 0 & 0 & 0 & 80 & 80 \\
\hline 23 & No Process Details - Assume SIC 22 & 0 & 0 & 0 & 80 & 80 \\
\hline 24 & Sawing & 0 & 40 & 40 & 50 & 50 \\
\hline 24 & Planning & 0 & 40 & 40 & 50 & 50 \\
\hline 25 & No Process Details - Assume SIC 24 & 0 & 40 & 40 & 50 & 50 \\
\hline 25 & No Process Details - Assume SIC 24 & 0 & 40 & 40 & 50 & 50 \\
\hline 26 & Chipper & 0 & 40 & 40 & 30 & 30 \\
\hline 26 & Dewatering Press & 5 & 10 & 10 & 50 & 50 \\
\hline 27 & No Process Details - Assume SIC 28 & 0 & 40 & 40 & 30 & 30 \\
\hline 27 & No Process Details - Assume SIC 28 & 5 & 10 & 10 & 50 & 50 \\
\hline 28 & Electrolysis & 30 & 60 & 60 & 0 & 0 \\
\hline 28 & Compressor & 25 & 60 & 60 & 60 & 60 \\
\hline 28 & Grinding & 0 & 40 & 40 & 30 & 30 \\
\hline 29 & Catalytic Cracking & 25 & 50 & 50 & 50 & 50 \\
\hline 30 & Mixing & 0 & 40 & 40 & 30 & 30 \\
\hline 30 & Mill & 0 & 40 & 40 & 30 & 30 \\
\hline 31 & No Process Details - Assume SIC 30 & 0 & 40 & 40 & 30 & 30 \\
\hline 31 & No Process Details - Assume SIC 30 & 0 & 40 & 40 & 30 & 30 \\
\hline 32 & Electric Furnace & 50 & 100 & 100 & 100 & 100 \\
\hline 32 & Crushing & 0 & 40 & 40 & 30 & 30 \\
\hline 33 & Electrolysis & 30 & 60 & 60 & 0 & 0 \\
\hline 33 & Crushing and Classifying & 0 & 40 & 40 & 30 & 30 \\
\hline 37 & Metal Cutting & 0 & 40 & 40 & 50 & 50 \\
\hline 37 & Final Assembly & 0 & 0 & 0 & 80 & 80 \\
\hline
\end{tabular}

